\title{
Environment, Safety, and Health Risk Assessment Program (ESHRAP)
}

Steven A Eide

Thomas E. Wierman

December 2003

Idaho National Engineering and Environmental Laboratory Bechtel BWXT Idaho, LLC 


\section{Environment, Safety, and Health Risk Assessment Program (ESHRAP)}

Steven A. Eide

Thomas E. Wierman

December 2003

Idaho National Engineering and Environmental Laboratory Risk, Reliability, and Regulatory Support Department Idaho Falls, Idaho 83415

Prepared for the

U.S. Department of Energy

Assistant Secretary for Environmental Management

Under DOE Idaho Operations Office

Contract DE-AC07-99ID13727 


\begin{abstract}
The Environment, Safety and Health Risk Assessment Program (ESHRAP) models human safety and health risk resulting from waste management and environmental restoration activities. Human safety and health risks include those associated with storing, handling, processing, transporting, and disposing of radionuclides and chemicals. Exposures to these materials, resulting from both accidents and normal, incident-free operation, are modeled. In addition, standard industrial risks (falls, explosions, transportation accidents, etc.) are evaluated.

Finally, human safety and health impacts from cleanup of accidental releases of radionuclides and chemicals to the environment are estimated. Unlike environmental impact statements and safety analysis reports, ESHRAP risk predictions are meant to be best estimate, rather than bounding or conservatively high. Typically, ESHRAP studies involve risk predictions covering the entire waste management or environmental restoration program, including such activities as initial storage, handling, processing, interim storage, transportation, and final disposal. ESHRAP can be used to support complex environmental decision-making processes and to track risk reduction as activities progress.
\end{abstract}




\section{SUMMARY}

The Environment, Safety and Health Risk Assessment Program (ESHRAP) models human safety and health risk resulting from waste management and environmental restoration activities. Human safety and health risks include those associated with storing, handling, processing, transporting, and disposing of radionuclides and chemicals. Exposures to these materials, resulting from both accidents and normal, incident-free operation, are modeled. In addition, standard industrial risks (falls, explosions, transportation accidents, etc.) are evaluated. Finally, human safety and health impacts from cleanup of accidental releases of radionuclides and chemicals to the environment are estimated. Unlike environmental impact statements and safety analysis reports, ESHRAP risk predictions are meant to be best estimate, rather than bounding or conservatively high. Typically, ESHRAP studies involve risk predictions covering the entire waste management or environmental restoration program, including such activities as initial storage, handling, processing, interim storage, transportation, and final disposal. ESHRAP can be used to support complex environmental decision-making processes and to track risk reduction as activities progress.

The accident portion of ESHRAP models releases of radionuclides and chemicals to the atmosphere and resultant exposures to workers, other site personnel, and the public within $80 \mathrm{~km}(50 \mathrm{mi})$ of the site. Lookup tables are provided in ESHRAP for most of the accident equation elements.

Releases of radionuclides and chemicals to the groundwater at sites are also modeled. Site-specific characteristics such as travel times through the vadose zone to the groundwater, site size, off-site population, and others are considered in the groundwater pathway model.

Radiological exposure to workers during normal, incident-free operation is modeled as a function of the number of workers associated with the activity in question. The total worker-hours for the activity are multiplied by an assumed yearly exposure (a user input). Exposure to site personnel and the public from treatment off-gas releases is also modeled.

Standard industrial risk is calculated based on the numbers of worker hours and support personnel hours associated with each activity. These hours are multiplied by appropriate fatality rates (fatalities/hour) for various activities.

Risk from transportation of waste includes accident and normal exposure, as well as standard industrial risk (fatalities resulting directly from a truck or rail accident). Normal exposure (to the crew and the public) occurring during transportation was modeled using a simple equation that approximates results of more detailed analyses. To predict fatalities caused by transportation accidents (part of the standard industrial risk), nation-wide accident rates (accidents/mile) and numbers of fatalities per truck and rail accident are used.

Disposal risk is evaluated for various waste/material types over a userspecified period (typically 10,000 years). The risks considered include intrusion events and transport to the groundwater and subsequent public exposure from 
wells. The transuranic waste disposal model is calibrated to the characteristics of the Waste Isolation Pilot Plant. The high-level waste and spent nuclear fuel disposal model is calibrated to Yucca Mountain. Low-level and mixed low-level waste disposal characteristics depend upon the site in question.

Finally, the environmental impact module covers human safety and health impacts from the cleanup of accidental releases of radionuclides and chemicals. Ecological impacts are not included.

The different types of risks modeled in ESHRAP - person-rem from radionuclides, latent cancer fatalities from chemicals, fatalities from standard industrial risks, and impacts measured in dollars - can be presented separately or combined into a total ES\&H risk picture. Conversion factors in the model are used to convert person-rem to latent cancer fatalities and then to dollars. Standard industrial accident fatalities are also converted to dollars. The conversion of fatalities to dollars also has the option to account for dollar impacts from standard industrial injuries and cancer incidences. The risk analyst has the option to change any of the conversion factors. 


\section{ACKNOWLEDGMENTS}

The precursor to ESHRAP is the work performed by G. Beitel and T. Smith as part of the site-wide integration effort performed at the Idaho National Engineering and Environmental Laboratory (INEEL) in 1995. R. Peatross and I. Stepan also contributed to early development efforts.

The Laboratory Directed Research and Development program at the INEEL provided most of the funding for ESHRAP development. Earlier funding came from a variety of sources, but mainly from Department of Energy Environmental Management complex integration projects. 


\section{CONTENTS}

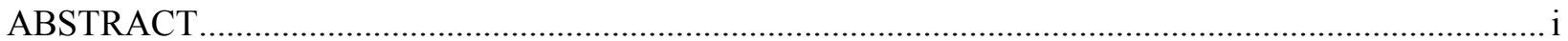

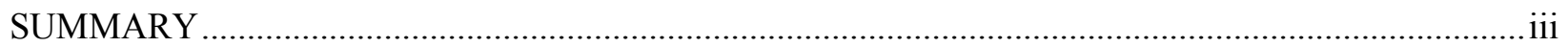

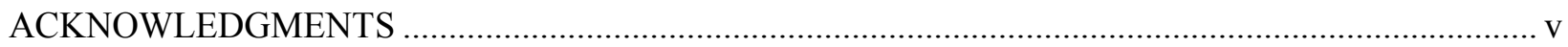

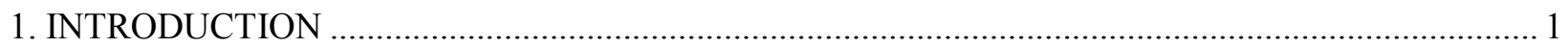

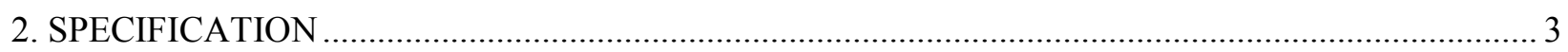

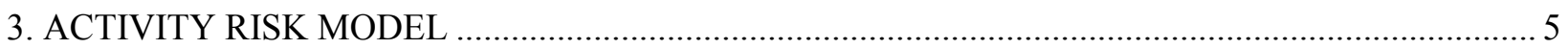

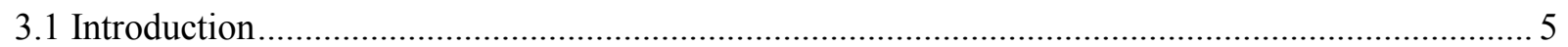

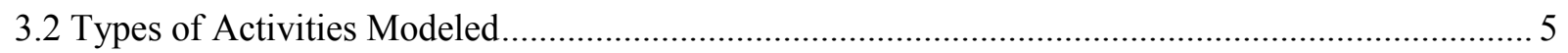

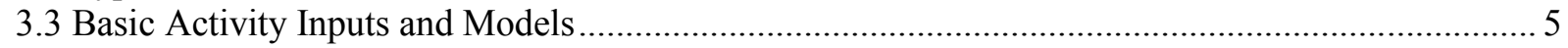

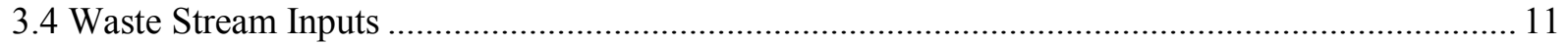

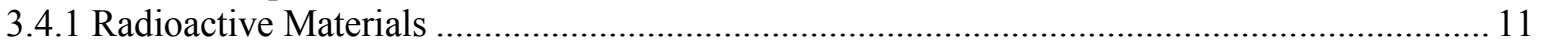

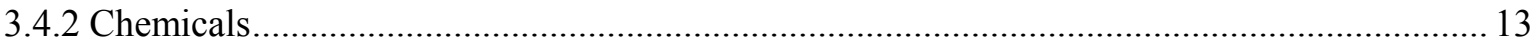

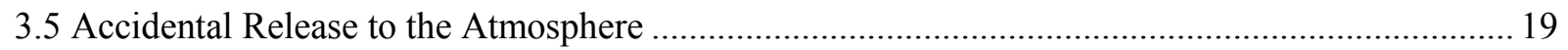

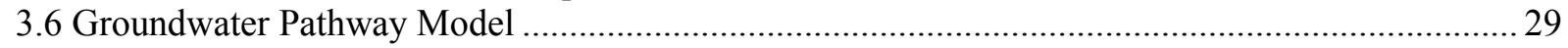

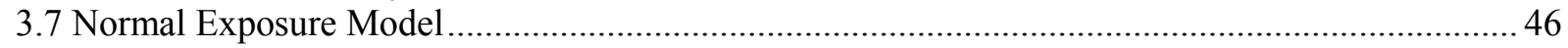

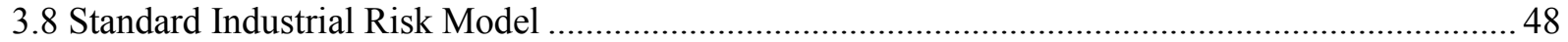

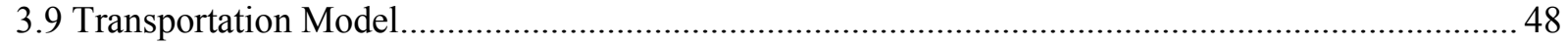

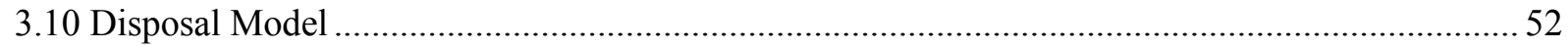

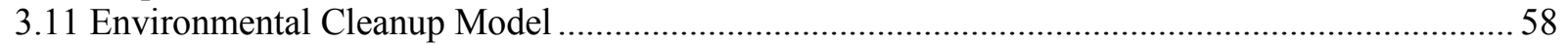

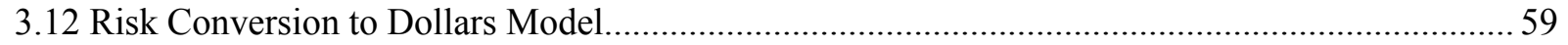

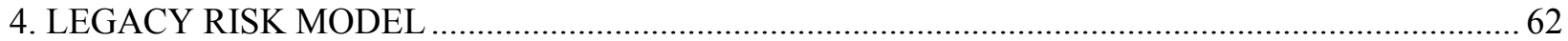

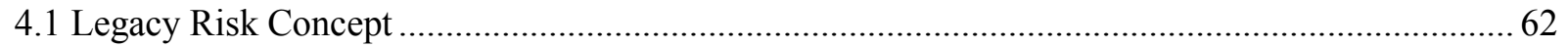

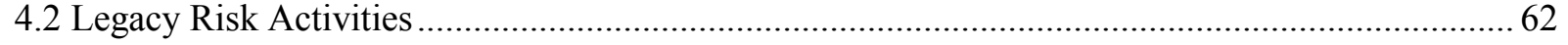

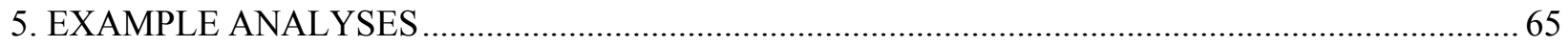

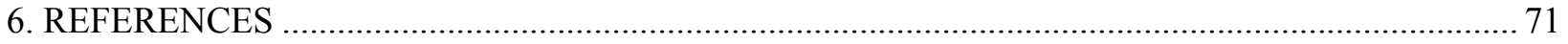

\section{FIGURES}

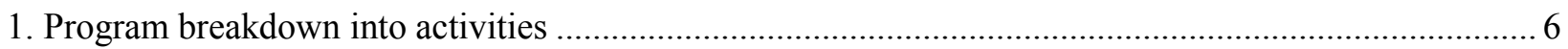

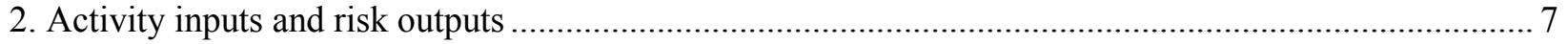

3. Actinide decay curves for waste/material categories ..................................................................... 12

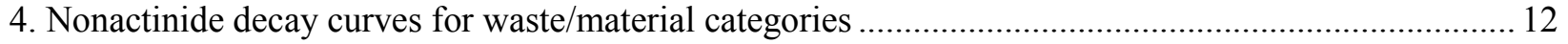

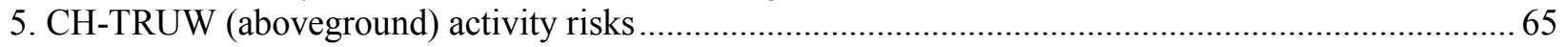

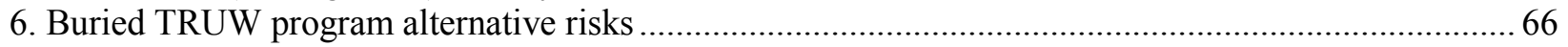

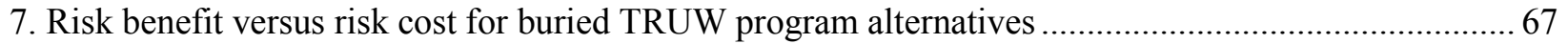

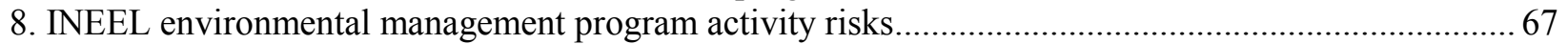

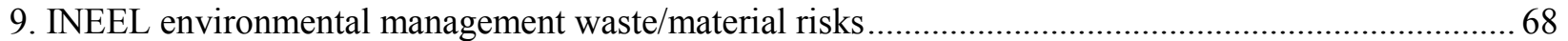

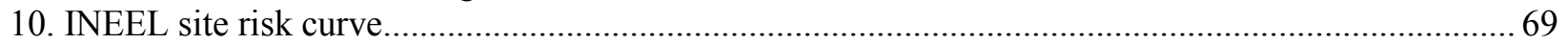

11. INEEL environmental management program risk integrated indicator ............................................. 69 


\section{TABLES}

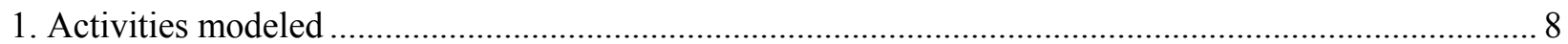

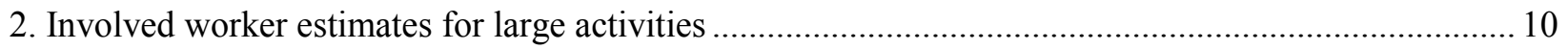

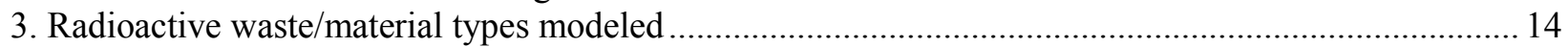

4. Indicator radionuclides used in vadose zone and groundwater transport......................................... 15

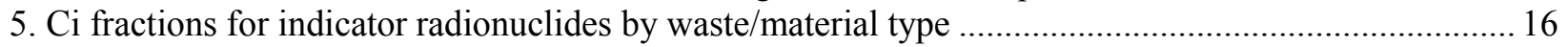

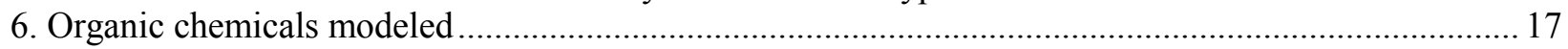

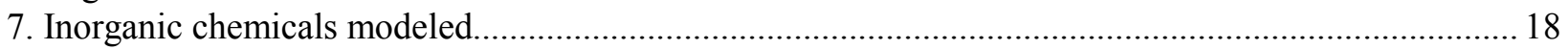

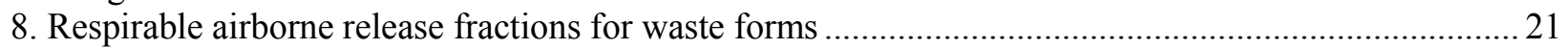

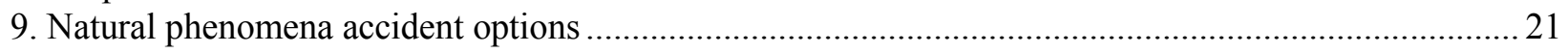

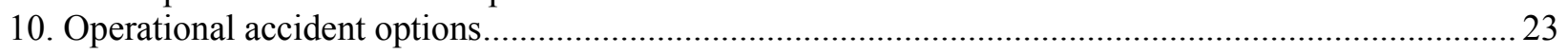

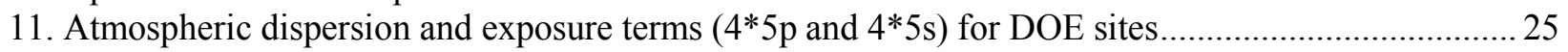

12. Evaluation of term $\left(4 * 5 \mathrm{p}_{24-\mathrm{h}}\right)$ for INEEL using Gaussian plume model ........................................ 26

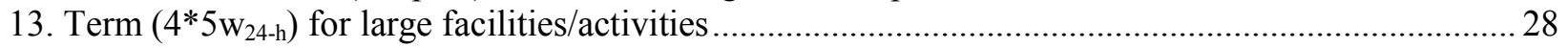

14. Site-specific groundwater pathway parameters except for distribution coefficients .......................... 33

15. Site-specific vadose zone distribution coefficients for indicator radionuclides................................. 34

16. Site-specific groundwater distribution coefficients for indicator radionuclides ................................. 35

17. Material form release to leachate parameters for indicator radionuclides ........................................ 35

18. Site-specific vadose zone distribution coefficients for organic chemicals ....................................... 36

19. Site-specific vadose zone distribution coefficients for inorganic chemicals ..................................... 38

20. Site-specific groundwater distribution coefficients for organic chemicals ......................................... 40

21. Site-specific groundwater distribution coefficients for inorganic chemicals ..................................... 42

22. Material form release to leachate parameters for organic chemicals ............................................... 44

23. Material form release to leachate parameters for inorganic chemicals ......................................... 45

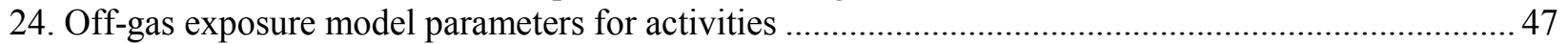

25. Reference $\mathrm{Ci} / \mathrm{V}$ concentrations for waste/material categories ............................................................ 48

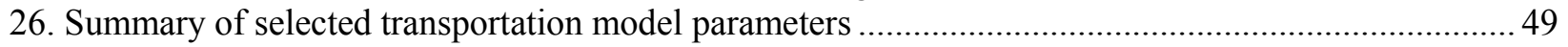

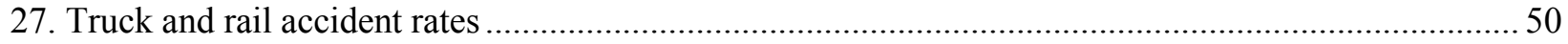

28. TRUW truck transport (TRUPACT-II) accident categories and release fractions ............................ 51

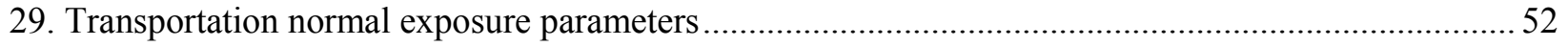

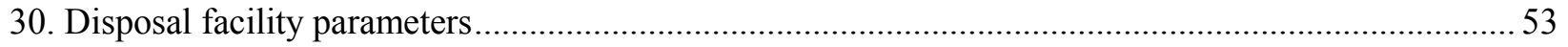

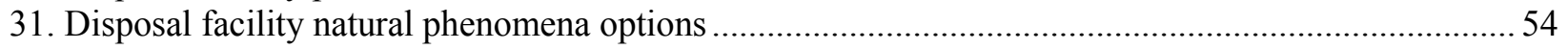

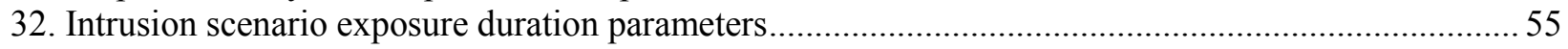

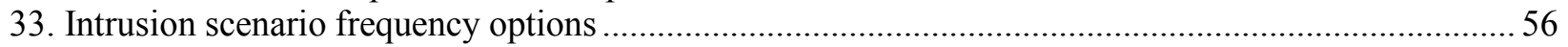

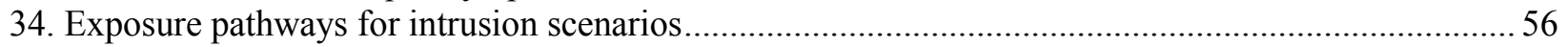

35. Initial radiation fields for waste/material categories placed into disposal ........................................ 58

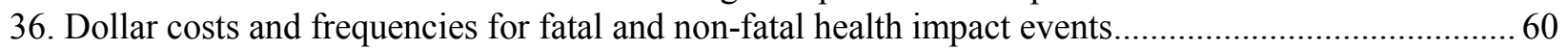

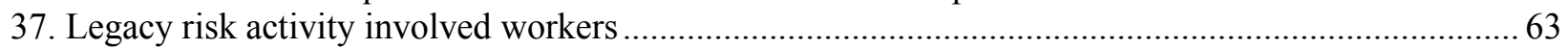

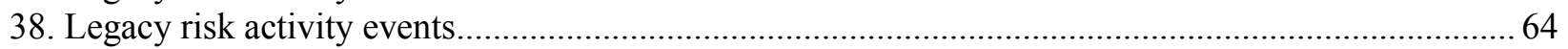




\section{ACRONYMS}

ANL - Argonne National Laboratory

ARF - Airborne Release Fraction

BNL - Brookhaven National Laboratory

BR - Breathing Rate

BRA - Baseline Risk Assessment

CAIRS - Computerized Accident/Injury Reporting System

CDI - Chronic Daily Intake

CERCLA - Comprehensive Environmental Response, Compensation, and Liability Act

CH-TRUW - Contact-Handled Transuranic Waste

CPP - Chemical Processing Plant

CRF - Concentration Reduction Factor

DOE - Department of Energy

DR - Damage Ratio

D\&D - Decontamination and Decommissioning

ED - Exposure Duration

EIS - Environmental Impact Statement

EPA - Environmental Protection Agency

ER - Erosion Rate

ESHRAP - Environment, Safety, and Health Risk Assessment Program

ES\&H - Environment, Safety, and Health

ETEC - Energy Technology Engineering Center

FEMP - Fernald Environmental Management Project

FI - Fraction Ingesting

HC - Hazard Category 
HEU - Highly Enriched Uranium

HLW - High-Level Waste

INEEL - Idaho National Engineering and Environmental Laboratory

IR - Ingestion Rate

IRF - Initial Radiation Field

IRIS - Integrated Risk Information System

ISF - Intrusion Scenario Frequency

KAPL-K - Knolls Atomic Power Laboratory - Kesselring

KCP - Kansas City Plant

LANL - Los Alamos National Laboratory

LBL - Lawrence Berkeley Laboratory

LFP - Leak Path Factor

LLNL - Lawrence Livermore National Laboratory

LLW - Low-Level Waste

MAR - Material at Risk

MDP - Middlesox Sampling Plant

MLLW - Mixed Low-Level Waste

$\mathrm{NP}$ - Number of People

NRC - Nuclear Regulatory Commission

NTS - Nevada Test Station

ORNL - Oak Ridge National Laboratory

OSHA - Occupational Safety and Health Administration

PA - Performance Assessment

PC - Performance Category

PEL-TWA - Permissible Exposure Limit Time-Weighted Average

PGDP - Paducah Gaseous Diffusion Plant 
RAIS - Risk Assessment Information System

RARF - Respirable Airborne Release Fraction

RF - Respirable Fraction

RfD - Reference Dose

RFETS - Rocky Flats Environmental Technology Site

RH-TRUW - Remote-Handled Transuranic Waste

SAR - Safety Analysis Report

SF - Slope Factor

SNF - Spent Nuclear Fuel

SNL-NM - Sandia National Laboratory - New Mexico

SNM - Special Nuclear Material

SRS - Savannah River Site

TRUW - Transuranic Waste

UC - Units Conversion

WIPP - Waste Isolation Pilot Plant

WVDP - West Valley Demonstration Project 


\section{ENVIRONMENT, SAFETY, AND HEALTH RISK ASSESSMENT PROGRAM (ESHRAP)}

\section{INTRODUCTION}

The Environment, Safety, and Health Risk Assessment Program (ESHRAP) is a software package developed to generate risk information to support decision making and performance measurement within the Department of Energy environmental management complex. Specifically, ESHRAP is used to support the development of a comprehensive risk model framework for the site or program in question. This framework involves two basic types of risk evaluations: risk from performing environmental management activities, and long-term legacy (no action) risk from wastes/materials. Results from these two types of risk assessments can be used to generate the following types of risk evaluations and comparisons:

- Risk evaluation of an entire program (covering waste/material as it now exists through disposal or other end states)

- Risk comparisons of alternative programs or activities

- Comparisons of risk benefit versus risk cost for activities or entire programs

- Ranking of programs or activities by risk

- Ranking of wastes/materials by risk

- Evaluation of site risk changes with time as activities progress

- Integrated performance measurement using indicators such as injury/death and exposure rates.

These types of risk evaluations and comparisons provide comprehensive risk information to the decisionmaking process. They also provide risk-based information on site risk reduction as activities progress.

Types of risks covered include human safety and health risks from exposures to radionuclides, chemicals, and standard industrial hazards, and human safety and health impacts from cleanup of releases of radionuclides or chemicals. Accidents and normal, incident-free operation are considered. Risk measures include total person-rem exposure to workers, other site personnel, and the public (radiological exposure only), and fatalities to the same groups (radiological, chemical, or standard industrial hazard exposures). To the extent possible, risk estimates are generated on a "best estimate" basis, rather than with a bounding or conservative bias.

ESHRAP is designed to provide comprehensive coverage of risk estimates. For program risk evaluations, the entire program is analyzed, from initial storage of wastes/materials through final disposition. Types of activities covered include the following: storage, retrieval, characterization, packaging, various treatment processes (both in situ and ex situ), loading/unloading, transportation (onsite and offsite), disposal, decontamination and decommissioning (D\&D), and long-term stewardship activities. For legacy risk evaluations, ESHRAP models long-term risk from groundwater contamination, atmospheric dispersion, and various types of intrusion scenarios.

ESHRAP analyses can be compared with risk analyses presented in environmental impact statements (EISs), performance assessments (PAs), baseline risk assessments (BRAs), and safety analysis reports (SARs). In general, the ESHRAP analyses are closest to EIS risk assessments in terms of risk coverage. Requirements for EISs are listed in the National Environmental Policy Act (Public Law 90-190, 1970). However, EIS risk assessments of waste/material programs often do not address all of the activities required from initial storage through disposition. Typically several representative (or bounding) activities 
are analyzed. Also, risk analyses in EISs are generally conservative or bounding analyses, rather than best estimate. Only some of the recent EISs have started to investigate the risk associated with true no action scenarios (legacy risk evaluations), and these analyses generally assume only one of each intrusion scenario considered occurs during the evaluation period (DOE 1997b and 2002c). Finally, health impacts from radiological, chemical, and standard industrial events are typically not combined into a single overall risk measure (fatalities or dollars).

PAs evaluate whether a disposal facility will meet regulatory requirements over a specified period such as 1,000 or 10,000 years. Therefore, the groundwater pathway evaluation is focused on whether the contaminant concentration in the groundwater a certain distance away from the facility (typically $100 \mathrm{~m}$ ) remains below a specified limit. Risk to the public from groundwater contamination is not evaluated, although it is assumed that this risk is small if the specified limit is not exceeded. PAs also typically evaluate the risks associated with one or more intrusion scenarios. However, multiple occurrences of such events are not considered. In contrast, ESHRAP analyses of disposal facilities include risks to the public from groundwater contamination and risks to intruders for a variety of intrusion scenarios (including the frequencies of such events). Also, ESHRAP analyses often cover more than just the post-closure phase of a disposal facility, including risks from waste management activities leading up to disposal.

BRAs are performed as part of the Comprehensive Environmental Response, Compensation, and Liability Act (CERCLA) or Superfund process (EPA 1989). These risk assessments are performed for a waste site before cleanup actions are performed. Risk to maximally exposed individuals is expressed in terms of the additional probability of a latent cancer fatality (for carcinogens) and/or hazard index results (for toxic effects). In a sense, BRAs are similar to the ESHRAP legacy risk analyses, but more limited. The BRAs do not factor in intrusion scenario frequencies and do not attempt to predict risk to the population within $80 \mathrm{~km}(50 \mathrm{mi})$.

Finally, SARs identify a representative set of accidents for a facility or operation and conservatively evaluate the risk from such accidents. Risk analyses typically address the resultant airborne concentration at a site boundary from such accidents and compare the results with site acceptance criteria (which may be a function of the accident frequency). SARs also conservatively estimate the normal exposure expected from the facility or operation and estimate the expected standard industry injuries and deaths. Therefore, SARs typically cover a single facility or operation, while ESHRAP analyses can cover the life cycle of the waste/material in question. Also, SAR analyses generally result in conservatively high risk estimates (to establish an operational envelope), while ESHRAP analyses attempt to be best estimate.

The purpose of this report is to present a specification for ESHRAP and a description of the models and technical bases. Report sections include the following: a specification for ESHRAP; a description of risk modeling for waste management, environmental restoration, D\&D, and long-term stewardship activities; a description of legacy risk models; sample applications of ESHRAP; and references. 


\section{SPECIFICATION}

The ESHRAP code was developed with a set of guidelines or specifications in mind. General characteristics of the ESHRAP code should include the following:

1. Capable of modeling risks in a simplified quantitative manner from many types of waste/material management, environmental restoration, D\&D, and long-term stewardship programs (with the INEEL as the initial focus). These programs include activities such as storage, handling, treatment, transportation, disposal, decontamination and decommissioning, and long-term monitoring. Risks should be evaluated on a best estimate basis, rather than a conservatively high basis as typically found in SARs and EISs.

2. Capable of modeling environment, safety, and health (ES\&H) risks from such programs. Safety and health risk to humans should include contributions from both accidents and incident-free operation. Accidents should include both natural phenomena (earthquakes, strong winds, range fires, and others) and operational or waste-related (fires, explosions, and others). Risks should be evaluated for workers and the public. Risks should include radiological exposures, hazardous chemical exposures (limited set of materials), and standard industrial accidents. Environmental risk in this context involves only the human safety and health risks associated with cleanup of the environment if hazardous materials are released to the environment. Ecological risk is not a part of the ESHRAP code specification at this time.

3. Capable of modeling risks of wastes/materials in any form and environmental setting. (The legacy risk concept provides this capability.)

4. Capable of supporting the following types of risk comparisons and evaluations:

- Risk evaluation of an entire program (covering waste/material as it now exists through disposal or other end states)

- Risk comparisons of alternative programs or activities

- Comparisons of risk benefit versus risk cost for activities or entire programs

- Ranking of programs or activities by risk

- Ranking of wastes/materials by risk

- Evaluation of site risk changes with time as activities progress

- Integrated performance measurement using indicators such as injury/death and exposure rates.

5. Capable of evaluating uncertainties and sensitivities associated with risk estimates.

Specific requirements for ESHRAP include the following:

1. Risks can be calculated for both activities and wastes/materials (legacy risk measures).

2. Risks include those from radiological, chemical, and standard industrial hazards.

3. Significant accident types are modeled.

4. Significant exposure pathways are modeled.

5. Significant environmental management, D\&D, and long-term stewardship activities are covered. 
6. Risk modeling reflects a best estimate philosophy rather than a conservative (bounding) basis.

7. Simplified modeling in the risk model framework appropriately matches results from state of the art models.

8. An appropriate set of U.S. Department of Energy (DOE) baseline data (standard industrial death rates, radiological exposures, accident frequencies, population distributions, and others) is identified/analyzed and incorporated into the models.

9. User inputs required to run ESHRAP are kept to a minimum to ensure ease of use in risk analyses. 


\section{ACTIVITY RISK MODELS}

\subsection{Introduction}

The ESHRAP code is used to model ES\&H risks from waste/material management and environmental restoration programs by breaking down programs into discrete activities. An example of this breakdown of programs into activities is shown in Figure 1. Each activity is then analyzed separately (Figure 2) and the results are combined to obtain overall program risks.

\subsection{Types of Activities Modeled}

ESHRAP is designed to handle a large variety of activities. The list is presented in Table 1. Activities are divided into four categories: waste/material management, environmental restoration, D\&D, and long-term stewardship. Waste/material management activity types include storage, handling, treatment, transportation, and disposal of wastes/materials. Environmental management includes capping and in-situ treatment. D\&D activity types include characterization, surveillance/maintenance, barrier enhancement, entombment, demolition, and removal. Finally, long-term stewardship includes monitoring and institutional control.

\subsection{Basic Activity Inputs and Models}

Basic information for each activity modeled is entered into ESHRAP. This information includes the type of activity, type (and amount) of waste/material involved, DOE site, start and end dates, natural phenomena design characteristics, and facility/waste accident frequencies and associated containment strength (for aboveground facilities). From these inputs, ESHRAP then calculates the human safety and health risks predicted to result from the activity. The overall process is illustrated in Figure 2.

Two basic models associated with the activities include the determination of the number of workers associated with the activity and the actual time needed to accomplish the activity. For all types of activities, there are two types of workers: involved and support. Involved workers are those who actually work with the waste, while support personnel provide office and managerial support. The number of involved workers is estimated by the following equation:

$$
\# \text { involved workers } \quad=\quad(\# \text { involved workers })_{\text {large facility }}(\text { volume/volume } \text { large facility })^{0.33}
$$

Estimates of involved workers for large facilities were approximated from supporting documents to the report Final Waste Management Programmatic Environmental Impact Statement for Managing Treatment, Storage, and Disposal of Radioactive and Hazardous Waste (DOE 1997a). These documents covered transuranic waste (TRUW) (Shropshire, Sherick, and Biagi 1995a), low-level waste (LLW) (Shropshire, Sherick, and Biagi 1995b), and spent nuclear fuel (SNF) (Feizollahi and Shropshire 1993). For TRUW and LLW, a large storage facility was defined to accommodate $50,000 \mathrm{~m}^{3}$ of waste. For handling activities, a large facility was defined to handle $50,000 \mathrm{~m}^{3}$ of waste at a processing rate of 2.5 $\mathrm{m}^{3} / \mathrm{h}$. This processing rate converts to $3500 \mathrm{~m}^{3} / \mathrm{y}$ assuming a capacity factor of $70 \%$. For treatment activities, a large facility was defined to handle $50,000 \mathrm{~m}^{3}$ of waste at a processing rate of $1000 \mathrm{~kg} / \mathrm{h}$. A representative conversion of $\mathrm{kg}$ to $\mathrm{m}^{3}$ is $250 \mathrm{~kg} / \mathrm{m}^{3}$ for TRUW and LLW. (DOE 1997b indicates a range of 96.6 to $2463.3 \mathrm{~kg} / \mathrm{m}^{3}$.) The processing rate of $1000 \mathrm{~kg} / \mathrm{h}$, or $4.0 \mathrm{~m}^{3} / \mathrm{h}$, converts to $5500 \mathrm{~m}^{3} / \mathrm{y}$ assuming a capacity factor of $70 \%$. For environmental restoration activities, processing rates and numbers of workers for large facilities were obtained from estimates generated (or actual numbers) for the INEEL (INEEL 2000). Finally, the exponent of 0.33 was estimated from Shropshire, Sherick, and Biagi (1995a) based on their estimates for small versus large facility numbers of workers. 


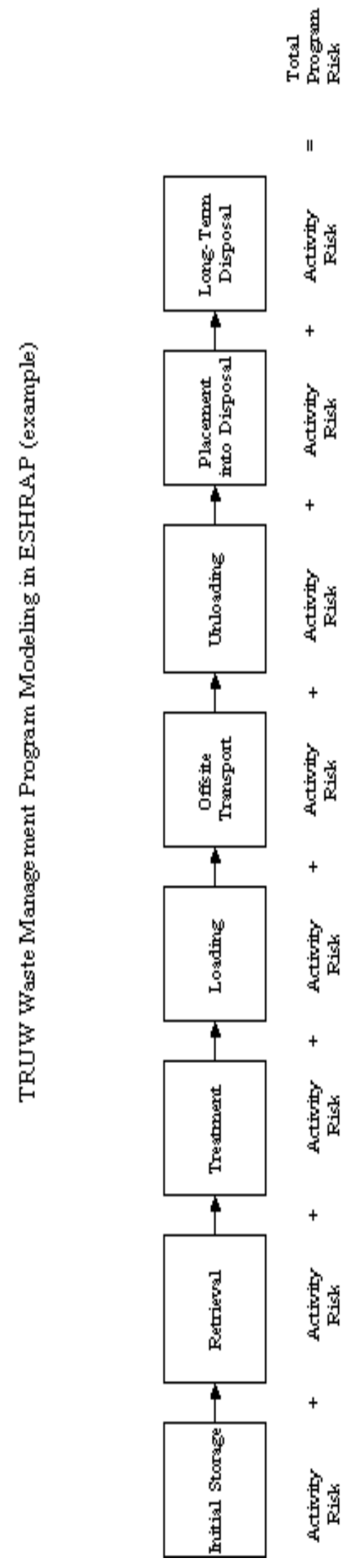

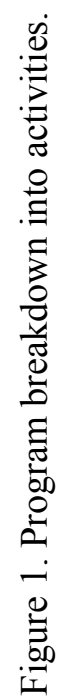




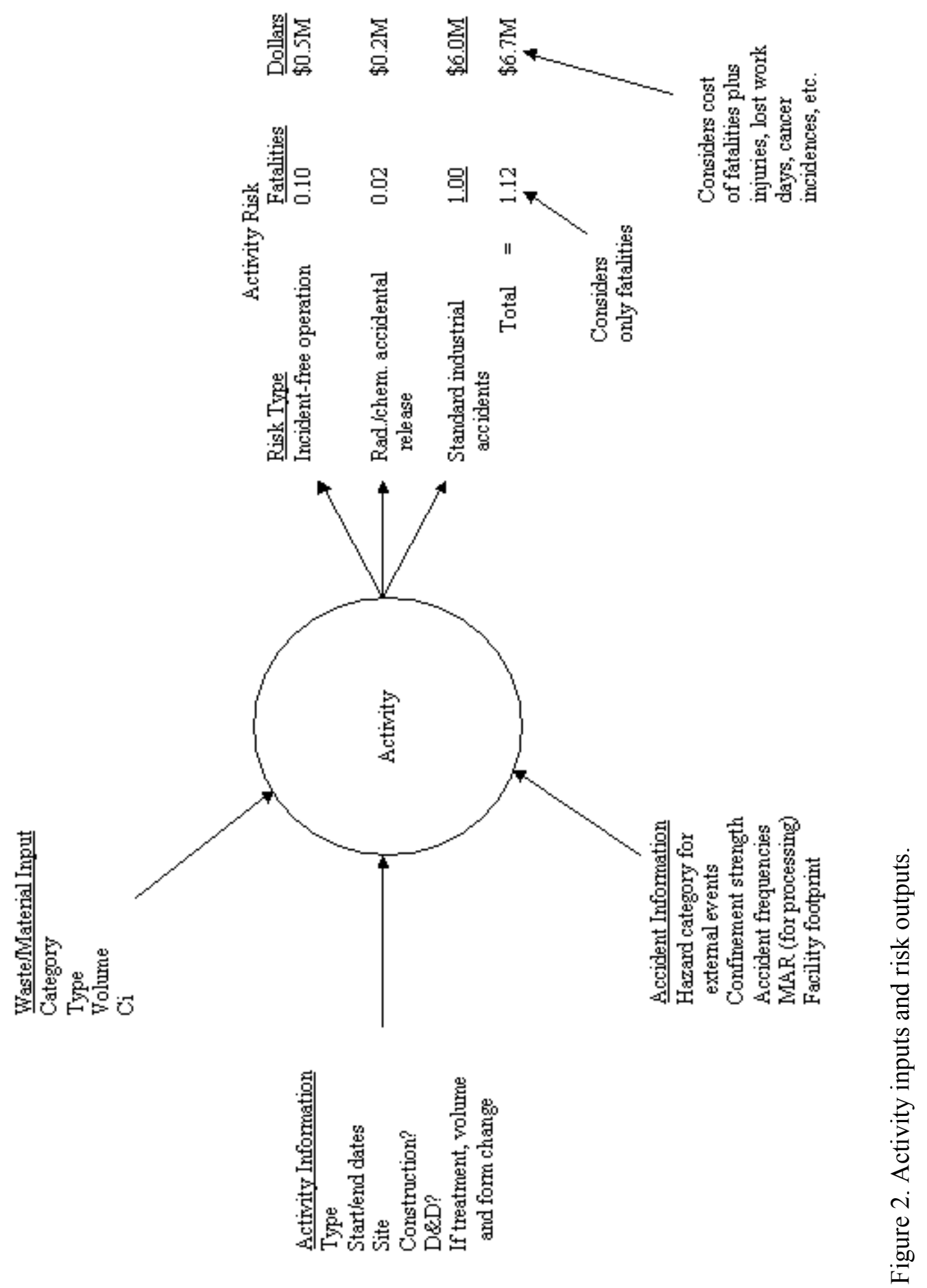


Table 1. Activities modeled.

\begin{tabular}{|c|c|c|c|}
\hline Activity Category & Activity Type & Activity & Examples \\
\hline \multirow[t]{19}{*}{$\begin{array}{l}\text { Waste/Material } \\
\text { Management }\end{array}$} & Storage & Aboveground & Building, Tank, Berm \\
\hline & & Belowground & Vault, Trench, Tank \\
\hline & Handling & Load/Unload & \\
\hline & & Placement (into disposal) & \\
\hline & & Retrieval (from storage) & \\
\hline & Treatment & Certification & \\
\hline & & Venting & \\
\hline & & Sort/Repackage & \\
\hline & & Waste Preparation & Shredding, Cutting \\
\hline & & Low Energy Treatment & $\begin{array}{l}\text { Solidification, Grouting, } \\
\text { Washing, } \\
\text { Decontamination }\end{array}$ \\
\hline & & $\begin{array}{l}\text { Moderate Energy } \\
\text { Treatment }\end{array}$ & $\begin{array}{l}\text { Evaporization, } \\
\text { Neutralization, Ion } \\
\text { Exchange }\end{array}$ \\
\hline & & High Energy Treatment & $\begin{array}{l}\text { Wet-Air Oxidation, } \\
\text { Vitrification, Incineration, } \\
\text { Thermal Desorption }\end{array}$ \\
\hline & Transportation & Truck & Onsite, Offsite \\
\hline & & Rail & Onsite, Offsite \\
\hline & & Pipe (aboveground) & \\
\hline & & Pipe (belowground) & \\
\hline & Disposal & Surface & LLW/MLLW \\
\hline & & Subsurface & LLW/MLLW \\
\hline & & Deep Geological & SNF/HLW/TRUW \\
\hline \multirow[t]{6}{*}{ Environmental Restoration } & Capping & Capping & \\
\hline & In-situ Treatment & Low Energy Treatment & Grouting \\
\hline & & $\begin{array}{l}\text { Moderate Energy } \\
\text { Treatment }\end{array}$ & \\
\hline & & High Energy Treatment & $\begin{array}{l}\text { Thermal Desorption, } \\
\text { Vitrification }\end{array}$ \\
\hline & Vapor Vacuum Extraction & Vapor Vacuum Extraction & \\
\hline & Pump and Treat & Pump and Treat & \\
\hline \multirow[t]{11}{*}{ D\&D } & Characterization & Characterization & \\
\hline & Surveillance/Maintenance & Surveillance/Maintenance & \\
\hline & Barrier Enhancement & Barrier Enhancement & \\
\hline & Entombment & Entombment & \\
\hline & Demolition & Demolition & \\
\hline & Decontamination & Decontamination & \\
\hline & Removal & $\begin{array}{l}\text { Loose Radioactive } \\
\text { Material Removal }\end{array}$ & \\
\hline & & $\begin{array}{l}\text { Loose/Fixed Hazardous } \\
\text { Waste Removal }\end{array}$ & Asbestos Removal \\
\hline & & $\begin{array}{l}\text { Irradiated Structure } \\
\text { Removal }\end{array}$ & \\
\hline & & Soil Removal & \\
\hline & & Buried Piping Removal & \\
\hline \multirow[t]{2}{*}{ Long-Term Stewardship } & Monitoring & Monitoring & \\
\hline & Institutional Control & Institutional Control & \\
\hline
\end{tabular}


For high-level waste (HLW) and SNF activities, the large facility and processing rate information developed for TRUW and LLW is assumed to be applicable.

For D\&D activities, the numbers of involved workers associated with large facilities and the times to complete the activities were estimated from information presented in Dettmers (2002). In general, information from that source is limited and was presented for combinations of activities. The breakdown into discrete activities was based on both additional information presented in the report and judgment. Several of the activities do not involve the storage or processing of waste. For those activities, a large facility was defined based on the building footprint $\left(2000 \mathrm{~m}^{3}\right)$ and number of stories (1), and the processing rate unit is 2000 or $5000 \mathrm{~m}^{2} / \mathrm{y}$, except for characterization, which is $25,000 \mathrm{~m}^{2} / \mathrm{y}$. Again, information was obtained from Dettmers (2002).

To estimate the number of support workers, a similar equation is used:

$$
\# \text { support workers }=\quad(\# \text { support workers })_{\text {large facility }}(\text { volume/volume } \text { large facility })^{0.33}
$$

However, none of the documents used to estimate the number of involved workers associated with large facilities contain information on the number of support workers. In general, one support worker is assumed for every involved worker, except for construction and D\&D activities.

Also modeled for each facility are associated construction and D\&D. Involved worker estimates for construction were obtained from the Shropshire, Sherick, and Biagi documents (1995a and b). The duration for construction is two years for less complex facilities and three years for others (DOE 1997a). Deep geological repositories are assumed to require five years for construction. D\&D activities are assumed to require 1.5 or three years. For construction and $\mathrm{D} \& \mathrm{D}$, one support worker is assumed for every two involved workers.

Exceptions to the general description presented above are indicated within the notes in the ESHRAP data tables. A summary of involved worker estimates for the various activities is presented in Table 2.

Another basic model associated with activities is the duration of the activity. There are two basic types of activities: storage and processing. All activities require a set of inputs indicating the start date and end date for the activity. The start and end dates are typically those shown on a planning schedule. For storage activities, the entire period from start date to end date is used for the activity. However, for processing types of activities, the code calculates the actual duration. That duration is determined by dividing the amount of waste to be processed $\left(\mathrm{m}^{3}\right)$ by the processing rate $\left(\mathrm{m}^{3} / \mathrm{y}\right)$. This actual duration for processing is then assumed to occur within the period specified by the start and end date inputs.

For the following D\&D activities, the processing rate is expressed as the building area covered per year $\left(\mathrm{m}^{2} / \mathrm{y}\right)$ : characterization, barrier enhancement, entombment, demolition, and decontamination. The activity duration is then calculated by dividing the building footprint $\left(\mathrm{m}^{2}\right)$ (times number of stories) by the processing rate.

Several monitoring types of activities are modeled, similar to storage activities with respect to the activity duration. These activities include D\&D surveillance and maintenance, and long-term stewardship institutional control monitoring. 
Table 2. Involved worker estimates for large activities.

\begin{tabular}{|c|c|c|c|c|c|}
\hline \multirow[t]{2}{*}{$\begin{array}{l}\text { Activity } \\
\text { Category }\end{array}$} & \multirow[t]{2}{*}{ Activity Type } & \multirow[t]{2}{*}{ Activity } & \multicolumn{3}{|c|}{$\begin{array}{l}\text { Number of Involved Workers for Large } \\
\text { Facility/Activity }\end{array}$} \\
\hline & & & Construction & Operations & $\begin{array}{l}\text { Decontamination } \\
\text { and } \\
\text { Decommissioning }\end{array}$ \\
\hline \multirow[t]{15}{*}{$\begin{array}{l}\text { Waste/Material } \\
\text { Management }\end{array}$} & $\begin{array}{l}\text { Storage } \\
\text { (Aboveground) }\end{array}$ & Building, Tank & 30 & 3 & 2 \\
\hline & & Berm & 30 & 1.5 & 2 \\
\hline & $\begin{array}{l}\text { Storage } \\
\text { (Belowground) }\end{array}$ & $\begin{array}{l}\text { Vault, Trench, } \\
\text { Tank }\end{array}$ & 30 & 1.5 & 2 \\
\hline & Handling & All & 40 & 25 & 2 \\
\hline & Treatment & Certification & 5 & 5 & 15 \\
\hline & & Venting & 10 & 10 & 15 \\
\hline & & Sort/Repackage & 100 & 50 & 15 \\
\hline & & $\begin{array}{l}\text { Waste } \\
\text { Preparation }\end{array}$ & 80 & 20 & 15 \\
\hline & & Low Energy & 90 & 15 & 15 \\
\hline & & $\begin{array}{l}\text { Moderate } \\
\text { Energy }\end{array}$ & 150 & 35 & 15 \\
\hline & & High Energy & 150 & 35 & 15 \\
\hline & Transportation & Truck & - & 2 & 2 \\
\hline & & Rail & - & 2 & 2 \\
\hline & & Pipe & 30 & 3 & 2 \\
\hline & Disposal & All & 20 & 2 & - \\
\hline \multirow{6}{*}{$\begin{array}{l}\text { Environmental } \\
\text { Restoration }\end{array}$} & Capping & Capping & - & 15 & - \\
\hline & In-situ treatment & $\begin{array}{l}\text { Low Energy } \\
\text { (grouting) }\end{array}$ & - & 10 & - \\
\hline & & $\begin{array}{l}\text { Moderate } \\
\text { Energy }\end{array}$ & - & 10 & - \\
\hline & & $\begin{array}{l}\text { High Energy } \\
\text { (thermal } \\
\text { desorption, } \\
\text { vitrification) }\end{array}$ & - & 10 & - \\
\hline & Extraction & $\begin{array}{l}\text { Vapor Vacuum } \\
\text { Extraction }\end{array}$ & 10 & 5 & 2 \\
\hline & & Pump and Treat & 10 & 5 & 2 \\
\hline \multirow[t]{3}{*}{$\mathrm{D} \& \mathrm{D}$} & Characterization & Characterization & - & 5 & - \\
\hline & $\begin{array}{l}\text { Surveillance/ } \\
\text { Maintenance }\end{array}$ & $\begin{array}{l}\text { Surveillance/ } \\
\text { Maintenance }\end{array}$ & - & 0.5 & - \\
\hline & Other & Other & - & 15 & - \\
\hline \multirow[t]{2}{*}{$\begin{array}{l}\text { Long-Term } \\
\text { Stewardship }\end{array}$} & Monitoring & Monitoring & $5^{a}$ & 0.5 & - \\
\hline & $\begin{array}{l}\text { Institutional } \\
\text { Control }\end{array}$ & $\begin{array}{l}\text { Institutional } \\
\text { Control }\end{array}$ & $5^{\mathrm{a}}$ & 2.0 & - \\
\hline
\end{tabular}

a. Construction covers the installation of monitoring devices or the building of the fence for institutional control. A construction duration of 0.1 year is assumed.

Finally transportation activities are assumed to occur uniformly during the period specified by the start and end date inputs. (Transportation risk is a function of the length and number of trips rather than some specified activity duration.) 


\subsection{Waste Stream Inputs}

\subsubsection{Radioactive Materials}

Activities generally involve the storage, processing, or transport of hazardous waste/material. Two general types of waste/material are modeled - radioactive and chemical. For the radioactive type, the user must input the volume of waste/material, the form (liquid, powder, glass, etc.) and the total curies (Ci). Also, the category of radioactive waste/material must be specified: SNF, HLW, contact-handled transuranic waste (CH-TRUW), remote-handled transuranic waste (RH-TRUW), LLW or mixed lowlevel waste (MLLW), or special nuclear material (SNM). Finally, within a radioactive waste/material category, a specific waste/material type must be chosen.

A specific waste/material type typically includes a variety of radionuclides, termed the radionuclide profile for that type. To simplify the modeling in ESHRAP, each waste/material type is broken down into actinide and nonactinide classes. Actinides are defined as long-lived (half-lives $>20$ years), alphaemitting radionuclides (atomic number of 89 or greater) and any existing (not future) decay products of actinides. All other radionuclides are classified as nonactinides. This breakdown into actinide and nonactinide classes was done for several reasons: (1) the decay curves for each class differ, (2) the split between actinide and nonactinide curies (Ci) varies by waste/material type, (3) the effective dose conversion factors differ, and (4) the partition coefficients $\left(\mathrm{k}_{\mathrm{d}}\right.$ 's) for vadose zone and groundwater transport differ. Each of these is illustrated in the discussions that follow.

The category of radioactive waste/material determines the decay tables used. For each radioactive waste/material type, ESHRAP contains decay tables for actinides and nonactinides. The decay tables up through 1000 years were generated by assuming specific mixes of radionuclides within the actinide and nonactinide categories and performing decay calculations using the RadDecay (Version 4) computer code developed by Grove Engineering, Inc. Later, the decay tables were extended through 1,000,000 years by spreadsheet calculations using only the dominant radionuclides. The mixes of radionuclides for each waste/material category generally were determined based on representative wastes/materials from various DOE EISs. Details of the decay table generation are presented in Eide et al. (1996). For simplicity, SNM was assumed not to decay over the time period zero to 1,000,000 years. Also, SNM does not have a nonactinide category. Figures 3 and 4 illustrate the decay curves for actinides and nonactinides for these waste/material categories. 


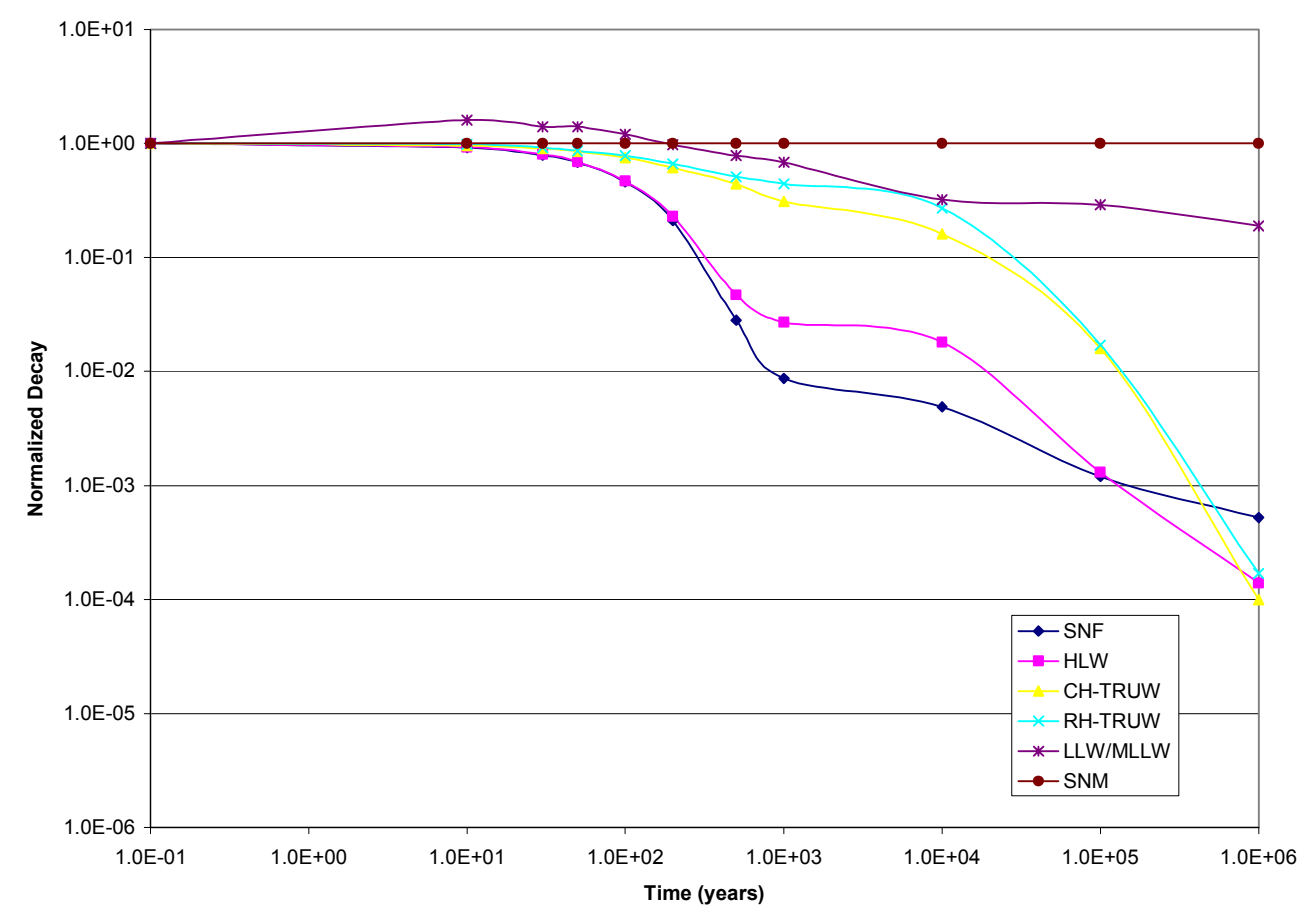

Figure 3. Actinide decay curves for waste/material categories.

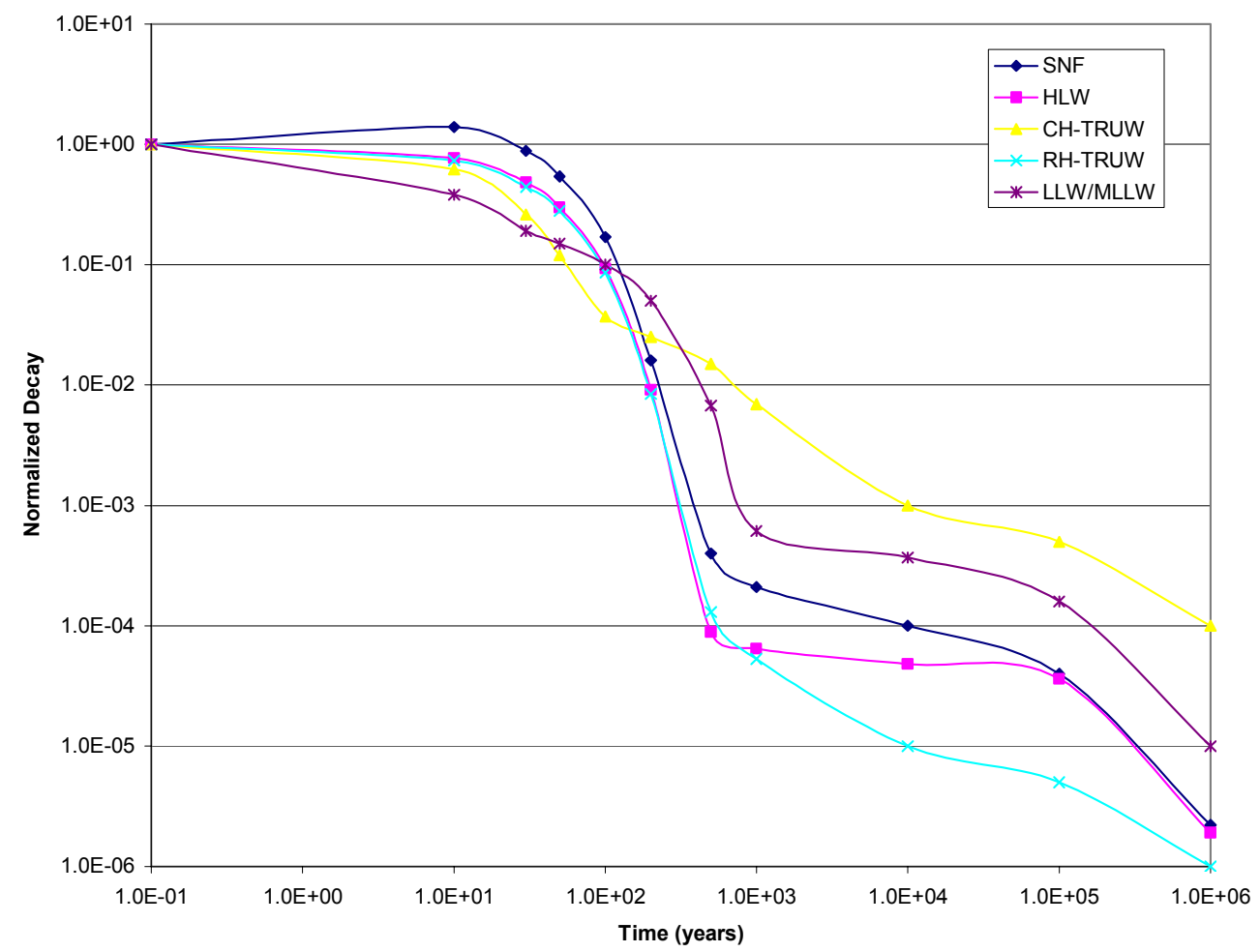

Figure 4. Nonactinide decay curves for waste/material categories.

Specific radioactive waste/material types included in ESHRAP are presented in Table 3. For each waste/material type, the percent actinide and dose conversion factors have been determined and are built 
into the data tables. The SNF information (radionuclide profiles - lists of radionuclides and associated Ci's) was obtained from the Department of Energy Programmatic Spent Nuclear Fuel Management and Idaho National Engineering Laboratory Environmental Restoration and Waste Management Programs Final Environmental Impact Statement (DOE 1995). Information for HLW and LLW/MLLW types was obtained from the Integrated Data Base Report-1995: U.S. Spent Nuclear Fuel and Radioactive Waste Inventories, Projections, and Characteristics (DOE 1996a). However, HLW information for the INEEL was obtained from the Idaho High-Level Waste \& Facilities Disposition Final Environmental Impact Statement (DOE 2002a). Finally, TRUW radionuclide profiles were obtained from the report Waste Isolation Pilot Plant Disposal Phase Final Supplemental Environmental Impact Statement (DOE 1997b). Table entries for "generic" waste/material types were estimated based on the specific waste/material results listed in Table 3. Special cases are noted within the data tables for ESHRAP.

Given the radionuclide profile information, the $\mathrm{Ci}$ fraction for actinides was determined. (The actinide $\mathrm{Ci}$ fraction is the total $\mathrm{Ci}$ of actinides divided by the total $\mathrm{Ci}$ of both actinides and nonactinides.) At time zero, this actinide fraction is applicable. However, as the actinides and nonactinides decay differentially, the actinide fraction varies with time.

The effective dose conversion factors for waste/material types were calculated by adding each radionuclide's dose conversion factor (multiplied by its $\mathrm{Ci}$ ) and then dividing the result by the total $\mathrm{Ci}$. This was performed separately for actinide inhalation, actinide ingestion, nonactinide inhalation, and nonactinide ingestion. Individual radionuclide dose conversion factors were obtained from Internal Dose Conversion Factors for Calculation of Dose to the Public (DOE 1988). Note that the effective dose conversion factors for a given radioactive waste type are assumed to remain constant over time, even though the radionuclide profile (within the actinide or nonactinide class) may vary with time as decay occurs.

Radionuclide effective dose conversion factors are used to convert exposures (inhalation or ingestion of radionuclides) to health impacts (radiation equivalent man, or rem), which can then be converted to carcinogenic effects (latent cancer fatalities). The radionuclide dose conversion factors are considered to be best estimate values (EPA 1989). Acute effects due to large doses of radiation are not modeled.

Finally, a set of indicator radionuclides is used in vadose zone and groundwater transport calculations. This set is presented in Table 4. These radionuclides were chosen based on their predicted contributions to risk at the INEEL Subsurface Disposal Area (Becker et al. 1998). Also shown in Table 4 are the decay half-lives and dose conversion factors for ingestion for these radionuclides. For the radioactive waste/material types listed in Table 3, conversion factors for each of the ten indicator radionuclides are built into ESHRAP. These factors convert the actinide (or nonactinide) $\mathrm{Ci}$ to indicator radionuclide $\mathrm{Ci}$. Table 5 presents these conversion factors.

\subsubsection{Chemicals}

Some of the radioactive waste/material types discussed in Section 2.2.3.1 may also contain hazardous chemicals. Also, some activities may include only hazardous chemicals (and no radionuclides). Unlike the radioactive waste/material risk modeling in ESHRAP, chemical risk is evaluated separately for each chemical specified. For each chemical, the user must input the volume, form, total $\mathrm{kg}$, and chemical name.

Decay for chemicals (analogous to radionuclide decay) can be modeled in ESHRAP for long-term disposal. For that activity, an effective environmental half-life for each chemical must be input. If no chemical half-life is specified, then a value of $1 \mathrm{E}+6$ years is assumed, which essentially allows no decay. 
Table 3. Radioactive waste/material types modeled.

\begin{tabular}{|c|c|c|c|c|c|c|}
\hline \multirow[t]{2}{*}{$\begin{array}{c}\text { Waste/ } \\
\text { Material } \\
\text { Category }\end{array}$} & \multirow[t]{2}{*}{ Waste/Material Type } & \multirow{2}{*}{$\begin{array}{c}\text { Actinide } \\
\text { Fraction } \\
\text { of Total } \\
\quad \mathrm{Ci}\end{array}$} & \multicolumn{2}{|c|}{$\begin{array}{c}\text { Dose Conversion } \\
\text { Factor (Actinide) } \\
\left.\text { (rem } / \mu \mathrm{Ci}_{\text {inhaled }}\right)\end{array}$} & \multicolumn{2}{|c|}{$\begin{array}{l}\text { Dose Conversion } \\
\text { Factor }(\text { Nonactinide) } \\
\left(\text { rem } / \mu \mathrm{Ci}_{\text {ingested }}\right)\end{array}$} \\
\hline & & & $\begin{array}{c}\text { Inhalation } \\
\text { Pathway }\end{array}$ & $\begin{array}{l}\text { Ingestion } \\
\text { Pathway }\end{array}$ & $\begin{array}{l}\text { Inhalation } \\
\text { Pathway }\end{array}$ & $\begin{array}{l}\text { Ingestion } \\
\text { Pathway }\end{array}$ \\
\hline \multirow[t]{8}{*}{ SNF } & Generic & $2.0 \mathrm{E}-2$ & $5.0 \mathrm{E}+1$ & $6.0 \mathrm{E}-1$ & $7.0 \mathrm{E}-2$ & $5.0 \mathrm{E}-2$ \\
\hline & Commercial & $2.5 \mathrm{E}-1$ & $3.3 \mathrm{E}+1$ & $3.5 \mathrm{E}-1$ & $1.3 \mathrm{E}-1$ & $8.9 \mathrm{E}-2$ \\
\hline & DOE $-E B R$ & $4.2 \mathrm{E}-2$ & $2.3 \mathrm{E}+1$ & $3.1 \mathrm{E}-1$ & $1.0 \mathrm{E}-2$ & $4.0 \mathrm{E}-3$ \\
\hline & Foreign & $2.2 \mathrm{E}-3$ & $1.5 \mathrm{E}+1$ & $2.0 \mathrm{E}-1$ & $1.3 \mathrm{E}-1$ & $8.9 \mathrm{E}-2$ \\
\hline & Graphite & $1.3 \mathrm{E}-2$ & $1.9 \mathrm{E}+2$ & $2.2 \mathrm{E}+0$ & $1.3 \mathrm{E}-1$ & $8.6 \mathrm{E}-2$ \\
\hline & Hanford N-Reactor & $1.3 \mathrm{E}-1$ & $3.1 \mathrm{E}+1$ & $3.6 \mathrm{E}-1$ & $1.2 \mathrm{E}-1$ & $8.6 \mathrm{E}-2$ \\
\hline & SRS Production Reactor & $1.3 \mathrm{E}-2$ & $1.4 \mathrm{E}+2$ & $1.7 \mathrm{E}+0$ & $1.3 \mathrm{E}-1$ & $9.0 \mathrm{E}-2$ \\
\hline & University & $9.0 \mathrm{E}-4$ & $5.9 \mathrm{E}+1$ & $7.5 \mathrm{E}-1$ & $3.0 \mathrm{E}-2$ & $2.0 \mathrm{E}-2$ \\
\hline \multirow[t]{9}{*}{ HLW } & Generic & $3.0 \mathrm{E}-3$ & $3.0 \mathrm{E}+2$ & $3.0 \mathrm{E}+0$ & $1.3 \mathrm{E}-1$ & $9.0 \mathrm{E}-2$ \\
\hline & Hanford Liquid/Sludge & $1.2 \mathrm{E}-3$ & $3.1 \mathrm{E}+2$ & $2.7 \mathrm{E}+0$ & $1.5 \mathrm{E}-1$ & $9.9 \mathrm{E}-2$ \\
\hline & Hanford Capsules & $0.0 \mathrm{E}+0$ & $3.5 \mathrm{E}+2$ & $3.0 \mathrm{E}+0$ & $9.0 \mathrm{E}-2$ & $7.4 \mathrm{E}-2$ \\
\hline & Hanford Glass & $1.7 \mathrm{E}-3$ & $4.5 \mathrm{E}+2$ & $3.9 \mathrm{E}+0$ & $1.5 \mathrm{E}-1$ & $9.9 \mathrm{E}-2$ \\
\hline & INEEL Liquid/Sludge - SBW & $7.4 \mathrm{E}-2$ & $2.1 \mathrm{E}+2$ & $2.5 \mathrm{E}+0$ & $1.6 \mathrm{E}-1$ & $1.0 \mathrm{E}-1$ \\
\hline & INEEL Calcine & $3.3 \mathrm{E}-3$ & $2.2 \mathrm{E}+2$ & $2.5 \mathrm{E}+0$ & $1.3 \mathrm{E}-1$ & $8.8 \mathrm{E}-2$ \\
\hline & SRS Liquid/Sludge & $5.5 \mathrm{E}-3$ & $2.2 \mathrm{E}+2$ & $2.7 \mathrm{E}+0$ & $1.3 \mathrm{E}-1$ & $9.1 \mathrm{E}-2$ \\
\hline & SRS Glass & $5.5 \mathrm{E}-3$ & $2.2 \mathrm{E}+2$ & $2.7 \mathrm{E}+0$ & $1.3 \mathrm{E}-1$ & $9.1 \mathrm{E}-2$ \\
\hline & WVDP & $5.5 \mathrm{E}-3$ & $2.8 \mathrm{E}+2$ & $2.3 \mathrm{E}+0$ & $1.3 \mathrm{E}-1$ & $8.8 \mathrm{E}-2$ \\
\hline \multirow[t]{8}{*}{ CH-TRUW } & Generic & $9.9 \mathrm{E}-1$ & $2.0 \mathrm{E}+2$ & $2.0 \mathrm{E}+0$ & $1.3 \mathrm{E}-1$ & $1.0 \mathrm{E}-1$ \\
\hline & Hanford & $9.8 \mathrm{E}-1$ & $2.4 \mathrm{E}+2$ & $3.0 \mathrm{E}+0$ & $1.3 \mathrm{E}-1$ & $9.0 \mathrm{E}-2$ \\
\hline & INEEL Retrievable & $1.0 \mathrm{E}+0$ & $2.5 \mathrm{E}+2$ & $2.5 \mathrm{E}+0$ & $1.5 \mathrm{E}-1$ & $4.5 \mathrm{E}-1$ \\
\hline & INEEL Buried & $1.7 \mathrm{E}-1$ & $1.1 \mathrm{E}+2$ & $1.1 \mathrm{E}+0$ & $1.5 \mathrm{E}-1$ & $5.0 \mathrm{E}-2$ \\
\hline & LANL & $1.0 \mathrm{E}+0$ & $3.2 \mathrm{E}+2$ & $4.0 \mathrm{E}+0$ & $1.4 \mathrm{E}-1$ & $1.6 \mathrm{E}-1$ \\
\hline & ORNL & $9.4 \mathrm{E}-1$ & $7.4 \mathrm{E}+1$ & $8.5 \mathrm{E}-1$ & $2.3 \mathrm{E}-1$ & $1.7 \mathrm{E}-1$ \\
\hline & RFETS & $1.0 \mathrm{E}+0$ & $1.2 \mathrm{E}+2$ & $1.3 \mathrm{E}+0$ & $1.3 \mathrm{E}-1$ & $1.0 \mathrm{E}-1$ \\
\hline & SRS & $1.0 \mathrm{E}+0$ & $2.5 \mathrm{E}+2$ & $3.2 \mathrm{E}+0$ & $6.0 \mathrm{E}-2$ & $2.0 \mathrm{E}-2$ \\
\hline \multirow[t]{5}{*}{ RH-TRUW } & Generic & $9.0 \mathrm{E}-2$ & $1.4 \mathrm{E}+2$ & $1.5 \mathrm{E}+0$ & $1.5 \mathrm{E}-1$ & $9.0 \mathrm{E}-2$ \\
\hline & Hanford & $1.7 \mathrm{E}-1$ & $5.9 \mathrm{E}+1$ & $6.7 \mathrm{E}-1$ & $1.3 \mathrm{E}-1$ & $8.7 \mathrm{E}-2$ \\
\hline & INEEL & $5.4 \mathrm{E}-2$ & $1.3 \mathrm{E}+2$ & $1.3 \mathrm{E}+0$ & $1.7 \mathrm{E}-1$ & $9.6 \mathrm{E}-2$ \\
\hline & LANL & $1.5 \mathrm{E}-1$ & $3.3 \mathrm{E}+2$ & $4.3 \mathrm{E}+0$ & $1.3 \mathrm{E}-1$ & $8.7 \mathrm{E}-2$ \\
\hline & ORNL & $4.7 \mathrm{E}-2$ & $1.4 \mathrm{E}+2$ & $1.3 \mathrm{E}+0$ & $1.8 \mathrm{E}-1$ & $9.7 \mathrm{E}-2$ \\
\hline \multirow[t]{3}{*}{ LLW/MLLW } & Generic (class A, B, or C) & $3.0 \mathrm{E}-3$ & $2.5 \mathrm{E}+2$ & $2.3 \mathrm{E}+0$ & $1.4 \mathrm{E}-1$ & $6.0 \mathrm{E}-2$ \\
\hline & Commercial Disposal & $1.0 \mathrm{E}-3$ & $2.8 \mathrm{E}+2$ & $1.9 \mathrm{E}+0$ & $1.5 \mathrm{E}-1$ & $3.1 \mathrm{E}-2$ \\
\hline & SRS Saltstone & $5.5 \mathrm{E}-3$ & $2.2 \mathrm{E}+2$ & $2.7 \mathrm{E}+0$ & $1.3 \mathrm{E}-1$ & $9.1 \mathrm{E}-2$ \\
\hline \multirow[t]{2}{*}{ SNM } & HEU & $1.0 \mathrm{E}+0$ & $1.3 \mathrm{E}+2$ & $3.0 \mathrm{E}-1$ & N/A & N/A \\
\hline & $\mathrm{Pu}-239$ & $1.0 \mathrm{E}+0$ & $3.3 \mathrm{E}+2$ & $4.3 \mathrm{E}+0$ & $\mathrm{~N} / \mathrm{A}$ & $\mathrm{N} / \mathrm{A}$ \\
\hline
\end{tabular}

Acronyms: CH-TRUW (contact-handled transuranic waste), CPP (Chemical Processing Plant), HEU (highly enriched uranium), HLW (high-level waste), INEEL (Idaho National Engineering and Environmental Laboratory), LANL (Los Alamos National Laboratory), LLW (low-level waste), MLLW (mixed low-level waste), ORNL (Oak Ridge National Laboratory), RH-TRUW (remote-handled transuranic waste), SNF (spent nuclear fuel), SNM (special nuclear material), SRS (Savannah River Site)

Analogous to dose conversion factors for radionuclides, carcinogenic slope factors are used for chemicals to convert exposure to cancer incidences. Then cancer incidences are converted to latent cancer fatalities. The organic and inorganic chemicals modeled in ESHRAP are presented in Tables 6 and 7, along with associated carcinogenic inhalation and ingestion slope factors (if available). The slope factors were obtained from the U.S. DOE Risk Assessment Information System (RAIS) (DOE 2003), which is based mainly on the Environmental Protection Agency (EPA) Integrated Risk Information System (IRIS) 
database (EPA 2002). However, RAIS includes slope factor estimates for more chemicals than does IRIS. Unlike radionuclide dose conversion factors, which are considered to be best estimate values, the carcinogenic slope factors are generally considered to be upper bound (95\%) values (EPA 1989). ESHRAP uses a multiplier (0.5) to reduce each chemical's carcinogenic slope factor to an approximate best estimate value. These multipliers are built into the data tables associated with chemicals and can be changed if desired.

Table 4. Indicator radionuclides used in vadose zone and groundwater transport.

\begin{tabular}{|l|l|l|l|}
\hline \multicolumn{1}{|c|}{ Category } & \multicolumn{1}{|c|}{ Radionuclide } & \multicolumn{1}{|c|}{ Decay Half-Life $(\mathrm{y})$} & $\begin{array}{c}\text { Dose Conversion Factor } \\
\left(\mathrm{rem} / \mu \mathrm{Ci}_{\text {iniested }}\right)\end{array}$ \\
\hline Nonactinide & $\mathrm{C}-14$ & $5.7 \mathrm{E}+3$ & $2.1 \mathrm{E}-3$ \\
\hline & $\mathrm{Sr}-90$ & $2.8 \mathrm{E}+1$ & $1.3 \mathrm{E}-1$ \\
\hline & $\mathrm{Tc}-99$ & $2.1 \mathrm{E}+5$ & $1.3 \mathrm{E}-3$ \\
\hline & $\mathrm{I}-129$ & $1.6 \mathrm{E}+7$ & $2.8 \mathrm{E}-1$ \\
\hline & $\mathrm{Cs}-137$ & $3.0 \mathrm{E}+1$ & $5.0 \mathrm{E}-2$ \\
\hline & $\mathrm{Ra}-226$ & $1.6 \mathrm{E}+3$ & $1.1 \mathrm{E}+0$ \\
\hline & $\mathrm{U}-234$ & $2.5 \mathrm{E}+5$ & $2.6 \mathrm{E}-1$ \\
\hline & $\mathrm{Np}-237$ & $2.1 \mathrm{E}+6$ & $3.9 \mathrm{E}+0$ \\
\hline & $\mathrm{U}-238$ & $4.5 \mathrm{E}+9$ & $2.7 \mathrm{E}-1$ \\
\hline & $\mathrm{Pu}-239$ & $2.4 \mathrm{E}+4$ & $4.3 \mathrm{E}+0$ \\
\hline
\end{tabular}

Many chemicals also exhibit noncarcinogenic toxicity. Noncarcinogenic toxicity risk in U.S. EPA risk assessments is not expressed as a probability of suffering an adverse effect (EPA 1989). Rather, the noncarcinogenic toxicity risk is represented by the hazard quotient, which is the exposure rate divided by the reference dose (RfD). EPA classifies RfDs by chronic (exposures of greater than seven years), subchronic (exposures ranging from two weeks to seven years), and short-term (up to two weeks). In general, ESHRAP is concerned with chronic exposures; however, short-term exposures result from accidental releases of chemicals to the atmosphere. Listed in Tables 6 and 7 are chronic RfDs (if available) for the chemicals modeled in ESHRAP (DOE 2003). The chronic RfD is the exposure rate below which no adverse health effects are expected.

Also listed in Tables 6 and 7 are short-term exposure limits for inhalation - permissible exposure limit time-weighted average (PEL-TWA). The PEL-TWA values are listed in Tables 6 and 7 because many of the chemicals do not have RfDs. The PEL-TWA is the eight hour/day concentration a worker can be exposed to without adverse effects. PEL-TWA values were obtained from the Occupational Safety \& Health Administration (OSHA 1997).

The risk measure for ESHRAP risk analyses is number of fatalities. In order for chemical noncarcinogenic effects to be included, an approximate conversion from hazard quotient results to equivalent probabilities of latent cancer incidence is needed. In ESHRAP, this conversion is based upon the assumption that a hazard quotient of 1.0 is weighted the same as a probability of $1.0 \mathrm{E}-4$ of a latent cancer incidence over a lifetime. (In DOE performance assessments and EPA guidance, chemicals resulting in hazard quotients $\geq 1.0$ or probabilities of latent cancer incidences $\geq 1.0 \mathrm{E}-4$ are highlighted as potentially unacceptable risks to an individual.) Linearity is also assumed, such that a hazard quotient of 100 is weighted the same as a probability of $1.0 \mathrm{E}-2$ of a latent cancer incidence. With this assumption, the noncarcinogenic limits in Tables 6 and 7 (RfD and PEL-TWA) can be accommodated by an "effective slope factor" concept. Then when carcinogenic risk is evaluated, the risk from noncarconogenic effects is also included. 


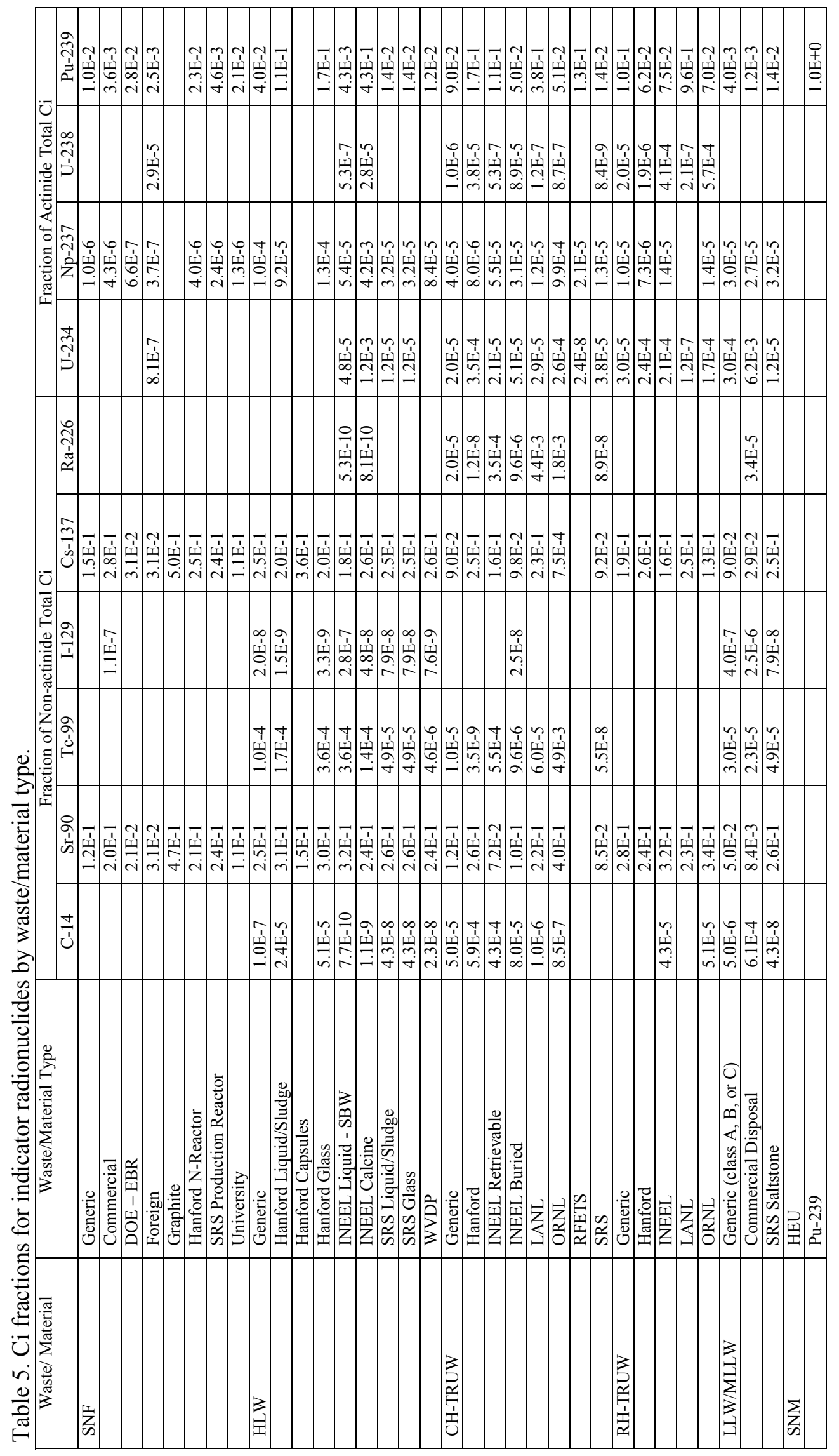


Table 6. Organic chemicals modeled.

\begin{tabular}{|c|c|c|c|c|c|}
\hline & \multicolumn{3}{|c|}{ Inhalation } & \multicolumn{2}{|c|}{ Ingestion (water) } \\
\hline Chemical/CAS Number & 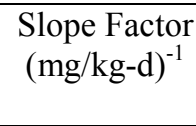 & $\begin{array}{c}\mathrm{RfD} \\
(\mathrm{mg} / \mathrm{kg}-\mathrm{d})\end{array}$ & $\begin{array}{l}\text { PEL-TWA } \\
\left(\mathrm{mg} / \mathrm{m}^{3}\right)\end{array}$ & $\begin{array}{c}\text { Slope } \\
\text { Factor } \\
(\mathrm{mg} / \mathrm{kg}-\mathrm{d})^{-1}\end{array}$ & $\begin{array}{c}\mathrm{RfD} \\
(\mathrm{mg} / \mathrm{kg}-\mathrm{d})\end{array}$ \\
\hline $\begin{array}{l}\text { 1,1,1-trichloroethane/ } \\
\text { 71-55-6 }\end{array}$ & & $6.3 \mathrm{E}-1$ & $1.9 \mathrm{E}+3$ & & $2.0 \mathrm{E}-1$ \\
\hline $\begin{array}{l}\text { 1,1,2,2-tetrachloroethane/ } \\
79-34-5\end{array}$ & $2.0 \mathrm{E}-1$ & & $3.5 \mathrm{E}+1$ & $2.0 \mathrm{E}-1$ & $6.6 \mathrm{E}-2$ \\
\hline $\begin{array}{l}\text { Acetone/ } \\
67-64-1\end{array}$ & & & $2.4 \mathrm{E}+3$ & & $1.0 \mathrm{E}-1$ \\
\hline $\begin{array}{l}\text { Benzene/ } \\
71-43-2\end{array}$ & $2.7 \mathrm{E}-2$ & $8.6 \mathrm{E}-3$ & $3.2 \mathrm{E}+1$ & $5.5 \mathrm{E}-2$ & $4.0 \mathrm{E}-3$ \\
\hline $\begin{array}{l}\text { Carbon disulfide/ } \\
75-15-0\end{array}$ & & $2.0 \mathrm{E}-1$ & $3.1 \mathrm{E}+1$ & & $1.0 \mathrm{E}-1$ \\
\hline $\begin{array}{l}\text { Carbon tetrachloride/ } \\
56-23-5\end{array}$ & $5.2 \mathrm{E}-2$ & & $6.3 \mathrm{E}+1$ & $1.3 \mathrm{E}-1$ & $7.0 \mathrm{E}-4$ \\
\hline $\begin{array}{l}\text { Chlorine/ } \\
7782-50-5\end{array}$ & & $5.7 \mathrm{E}-5$ & & & $1.0 \mathrm{E}-1$ \\
\hline $\begin{array}{l}\text { Chloroform/ } \\
67-66-3\end{array}$ & $8.0 \mathrm{E}-2$ & & $2.4 \mathrm{E}+2$ & $6.1 \mathrm{E}-3$ & $1.0 \mathrm{E}-2$ \\
\hline $\begin{array}{l}\text { Ethylbenzene/ } \\
100-41-4\end{array}$ & $3.8 \mathrm{E}-3$ & $2.9 \mathrm{E}-1$ & $4.3 \mathrm{E}+2$ & & $1.0 \mathrm{E}-1$ \\
\hline $\begin{array}{l}\text { Methylene chloride } \\
\text { (dichloromethane)/ } \\
75-09-2\end{array}$ & $1.6 \mathrm{E}-3$ & $8.6 \mathrm{E}-1$ & $1.7 \mathrm{E}+2$ & $7.5 \mathrm{E}-3$ & $6.0 \mathrm{E}-2$ \\
\hline $\begin{array}{l}\text { PCBs-aroclor 1016/ } \\
12674-11-2\end{array}$ & & & $5.0 \mathrm{E}-1$ & & $7.0 \mathrm{E}-5$ \\
\hline $\begin{array}{l}\text { PCBs-aroclor 1254/ } \\
11097-69-1\end{array}$ & & & $5.0 \mathrm{E}-1$ & & $2.0 \mathrm{E}-5$ \\
\hline $\begin{array}{l}\text { Tetrachloroethylene/ } \\
7127-18-4\end{array}$ & $2.0 \mathrm{E}-3$ & $1.7 \mathrm{E}-1$ & & $5.2 \mathrm{E}-2$ & $1.0 \mathrm{E}-2$ \\
\hline $\begin{array}{l}\text { Toluene/ } \\
108-88-3\end{array}$ & & $1.1 \mathrm{E}-1$ & $7.5 \mathrm{E}+2$ & & $2.0 \mathrm{E}-1$ \\
\hline $\begin{array}{l}\text { Trichloroethylene (TCE)/ } \\
79-01-6\end{array}$ & $4.0 \mathrm{E}-1$ & $1.1 \mathrm{E}-2$ & & $4.0 \mathrm{E}-1$ & $3.0 \mathrm{E}-4$ \\
\hline
\end{tabular}

As an example, consider the chemical carbon tetrachloride and the ingestion pathway in Table 6. If a probability of cancer incidence of 1.0E-4 is assumed, then the corresponding chronic daily intake (CDI) can be calculated by the following equation (EPA 1989):

Risk $\quad=\quad \mathrm{CDI} * \mathrm{SF}$,

where Risk $=$ probability of cancer incidence (from exposure considered)

$\mathrm{CDI}=$ chronic daily intake $\left(\mathrm{mg}_{\text {ingested }} / \mathrm{kg}_{\text {body mass }} \mathrm{-d}\right)$

$\mathrm{SF}=$ inhalation slope factor (cancer incidence $/\left(\mathrm{mg}_{\text {ingested }} / \mathrm{kg}_{\text {body mass }}-\mathrm{d}\right)$.

From Table 6, the ingestion SF for carbon tetrachloride is 1.3E-1. Solving for CDI (corresponding to a probability of cancer incidence of $1.0 \mathrm{E}-4$ ) results in $7.7 \mathrm{E}-4 \mathrm{mg}_{\text {ingested }} / \mathrm{kg}_{\text {body mass }}-\mathrm{d}$. Now calculate the corresponding hazard quotient assuming this same CDI. The hazard quotient is just the CDI divided by the RfD (7.0E-4 from Table 5), or 7.7E-4/7.0E-4 = 1.1. If a hazard quotient of 1.0 is weighted the same as a $1.0 \mathrm{E}-4$ probability of cancer incidence, then a hazard quotient of 1.1 is similar to $1.1 \mathrm{E}-4$ probability of 
cancer incidence. Therefore, given a CDI of 7.7E-4, the total risk is $1.0 \mathrm{E}-4$ (carcinogenic effects) plus $1.1 \mathrm{E}-4$ (noncarcinogenic effects), or 2.1E-4. In this case the noncarcinogenic contribution to risk is $110 \%$ of the carcinogenic contribution. Because ESHRAP risk equations calculate only the carcinogenic contribution, the SF is modified to an effective SF to include the noncarcinogenic effects. This is done by calculating the noncarcinogenic contribution to the effective SF using Equation (3). Therefore, the effective SF contribution is $1.1 \mathrm{E}-4 / 7.7 \mathrm{E}-4=1.4 \mathrm{E}-1$. This is then represented by the expression (x)/RfD. Solving for $\mathrm{x}$ results in $\mathrm{x}=(1.4 \mathrm{E}-1)(7.0 \mathrm{E}-4)=1.0 \mathrm{E}-4$ (reflecting the assumption that a hazard quotient of 1.0 is weighted the same as a 1.0E-4 probability of cancer incidence). Therefore, if an RfD is listed in Table 6 or 7, then its contribution to the effective SF is 1E-4/RfD.

Table 7. Inorganic chemicals modeled.

\begin{tabular}{|c|c|c|c|c|c|}
\hline \multirow{2}{*}{$\begin{array}{l}\text { Chemical/ } \\
\text { CAS Number }\end{array}$} & \multicolumn{3}{|c|}{ Inhalation } & \multicolumn{2}{|c|}{ Ingestion (water) } \\
\hline & $\begin{array}{l}\text { Slope Factor } \\
(\mathrm{mg} / \mathrm{kg}-\mathrm{d})^{-1}\end{array}$ & $\begin{array}{c}\mathrm{RfD} \\
(\mathrm{mg} / \mathrm{kg}-\mathrm{d})\end{array}$ & $\begin{array}{c}\text { PEL-TWA } \\
\left(\mathrm{mg} / \mathrm{m}^{3}\right)\end{array}$ & $\begin{array}{c}\text { Slope } \\
\text { Factor } \\
(\mathrm{mg} / \mathrm{kg}-\mathrm{d})^{-1}\end{array}$ & $\begin{array}{c}\mathrm{RfD} \\
(\mathrm{mg} / \mathrm{kg}-\mathrm{d})\end{array}$ \\
\hline $\begin{array}{l}\text { Antimony/ } \\
7440-36-0\end{array}$ & & & $5.0 \mathrm{E}-1$ & & $4.0 \mathrm{E}-4$ \\
\hline $\begin{array}{l}\text { Arsenic/ } \\
7440-38-2\end{array}$ & $1.5 \mathrm{E}+1$ & & $1.0 \mathrm{E}-2$ & $1.5 \mathrm{E}+0$ & $3.0 \mathrm{E}-4$ \\
\hline $\begin{array}{l}\text { Asbestos/ } \\
1332-21-4\end{array}$ & $2.7 \mathrm{E}+1^{\mathrm{a}}$ & & & & \\
\hline $\begin{array}{l}\text { Beryllium/ } \\
7440-41-7\end{array}$ & $8.4 \mathrm{E}+0$ & $5.7 \mathrm{E}-6$ & $2.0 \mathrm{E}-3$ & $4.3 \mathrm{E}+0$ & $2.0 \mathrm{E}-3$ \\
\hline $\begin{array}{l}\text { Cadmium/ } \\
7440-43-9\end{array}$ & $6.3 \mathrm{E}+0$ & & $5.0 \mathrm{E}-2$ & & $5.0 \mathrm{E}-4$ \\
\hline $\begin{array}{l}\text { Chromium-3/ } \\
7440-47-3 \\
\end{array}$ & & & $5.0 \mathrm{E}-1$ & & $1.5 \mathrm{E}+0$ \\
\hline $\begin{array}{l}\text { Chromium-6/ } \\
7440-47-3 \\
\end{array}$ & $4.2 \mathrm{E}+1$ & $2.9 \mathrm{E}-5$ & & & $3.0 \mathrm{E}-3$ \\
\hline $\begin{array}{l}\text { Hydrogen fluoride/ } \\
7664-39-3\end{array}$ & & & $2.5 \mathrm{E}+0$ & & \\
\hline $\begin{array}{l}\text { Lead/ } \\
7439-92-1\end{array}$ & & $4.3 \mathrm{E}-4$ & $5.0 \mathrm{E}-2$ & & \\
\hline $\begin{array}{l}\text { Mercury/ } \\
7439-97-6\end{array}$ & & $8.6 \mathrm{E}-5$ & $1.0 \mathrm{E}-1$ & & $3.0 \mathrm{E}-4$ \\
\hline $\begin{array}{l}\text { Nickel/ } \\
7440-02-0\end{array}$ & & & $1.0 \mathrm{E}+0$ & & $2.0 \mathrm{E}-2$ \\
\hline $\begin{array}{l}\text { Nitrates/ } \\
14797-55-8\end{array}$ & & & & & $1.6 \mathrm{E}+0$ \\
\hline $\begin{array}{l}\text { Nitric acid/ } \\
7697-37-2\end{array}$ & & & $5.0 \mathrm{E}+0$ & & \\
\hline $\begin{array}{l}\text { Selenium/ } \\
7782-49-2\end{array}$ & & & $2.0 \mathrm{E}-1$ & & $5.0 \mathrm{E}-3$ \\
\hline $\begin{array}{l}\text { Sulfuric acid/ } \\
7664-93-9\end{array}$ & & $2.0 \mathrm{E}-1$ & $1.0 \mathrm{E}+0$ & & \\
\hline $\begin{array}{l}\text { Uranium/ } \\
7440-61-1\end{array}$ & & & $2.5 \mathrm{E}-1$ & & $3.0 \mathrm{E}-3$ \\
\hline
\end{tabular}

a. Derived from an inhalation unit risk of $0.23 /$ fiber $/ \mathrm{mL}$ and a recommended conversion factor of 30 $\left(\mu \mathrm{g} / \mathrm{m}^{3}\right) /($ fiber $/ \mathrm{mL})($ EPA 2002).

If an inhalation RfD is not available, the PEL-TWA can also be used to approximate the noncarcinogenic contribution to the effective SF. Inhalation RfDs can be converted to equivalent airborne concentrations $\left(\mathrm{mg} / \mathrm{m}^{3}\right)$ by multiplying by the expression $\left(20 \mathrm{~m}^{3} / \mathrm{d}\right) *(1 / 70 \mathrm{~kg})$. [The EPA best estimate 
breathing rate is $20 \mathrm{~m}^{3} / \mathrm{d}$ and the average adult body weight is $70 \mathrm{~kg}$ (EPA 1989).] Then these airborne concentrations can be compared with the PEL-TWAs. In Tables 6 and 7, there are six chemicals with values for inhalation RfD and PEL-TWA. The ratio of PEL-TWA concentration to RfD-derived concentration ranges from approximately 20 to more than 20,000. A geometric average is approximately 1000, indicating that the PEL-TWA limit is approximately 1000 times higher than the RfD-derived limit. Therefore, if only a PEL-TWA is available, the contribution to the effective SF is (1.0E4/RfD $)(\mathrm{RfD} * 20 / 70) /(\mathrm{PEL}-\mathrm{TWA} / 1000)=2.9 \mathrm{E}-2 / \mathrm{PEL}-\mathrm{TWA}$, which is rounded to 3E-2/PEL-TWA. Note that this is a very rough approximation because of the large range of concentration ratios (20 to more than 20,000) reflected in Tables 6 and 7.

Unlike radionuclides, no indicator chemicals are built into ESHRAP for vadose zone and groundwater transport calculations. The user must specify each chemical to be analyzed.

\subsection{Accidental Release to the Atmosphere}

ESHRAP models several different types of accidents: accidental releases of radionuclides and/or chemicals into the atmosphere, long-term releases to groundwater, and standard industrial accidents. This section discusses the modeling of accidental releases into the atmosphere. Subsequent sections discuss the modeling of other types of accidents, as well as risk from normal, incident-free operation.

ESHRAP models releases of radionuclides and chemicals to the atmosphere and resultant exposures to workers, other site personnel, and the public within $80 \mathrm{~km}(50 \mathrm{mi})$ of the site. The accident equation for atmospheric releases is the following:

$$
\text { Risk }_{\text {accident }}=(1 \mathrm{a})\left(1 \mathrm{a}_{\text {decay }}\right)(1 \mathrm{~b})(2 \mathrm{a})\left(\sum 2 \mathrm{~b} * 3 \mathrm{a}+\sum 2 \mathrm{~b} * 3 \mathrm{~b}\right)\left(4 * 5 \mathrm{w}_{24-\mathrm{h}}+4 * 5 \mathrm{~s}_{24-\mathrm{h}}+4 * 5 \mathrm{p}_{24-\mathrm{h}}\right)(6)(7)
$$

where Risk $\mathrm{accident}_{\mathrm{N}}=\quad$ risk to workers, other site personnel, and the public from accidental

$\left(1 \mathrm{a}_{\text {decay }}\right)$

(1b)

$\left(4 * 5 \mathrm{w}_{24-\mathrm{h}}\right)$

$\left(4 * 5 \mathrm{~s}_{24-\mathrm{h}}\right) \quad=$ $\left(4 * 5 \mathrm{p}_{24-\mathrm{h}}\right) \quad=$ releases of radionuclides or chemicals into the atmosphere (fatalities) $=\quad$ inventory [curies $(\mathrm{Ci})$ or $\mathrm{kg}$ for chemicals]

$=\quad$ fractional decay of inventory

$=\quad$ toxicity of inventory $\left[\right.$ dose conversion factor $\left(\mathrm{rem} / \mu \mathrm{Ci} \mathrm{i}_{\text {inhaled }}\right)$ or slope factor (cancer incidence $/ \mathrm{mg}_{\text {inhaled }} /\left(\mathrm{kg}_{\text {body mass }}\right.$ - day)]

$=$ respirable airborne release fraction (function of material form and accident characteristics)

$=\quad$ containment failure probability or leak path factor

$=\quad$ natural phenomena accident frequency multiplied by material at risk and damage fractions $\left(\mathrm{y}^{-1}\right)$

$=\quad$ operational accident frequency multiplied by material at risk and damage fractions $\left(\mathrm{y}^{-1}\right)$

$=\quad$ unit $\mathrm{Ci}$ or $\mathrm{kg}$ exposure to facility workers resulting from atmospheric dispersion and inhalation $\left(\mu \mathrm{Ci}_{\text {inhaled }} / \mathrm{Ci}_{\text {released }}\right.$ or $\left.\mathrm{mg}_{\text {inhaled }} / \mathrm{kg}_{\text {released }}\right)$

$=\quad$ similar to $4 * 5 \mathrm{w}$ but for other DOE site personnel

$=\quad$ similar to $4 * 5 \mathrm{w}$ but for the public within 80 kilometers $(50$ miles of the site)

$=\quad$ time duration for activity $(\mathrm{y})$

$=\quad$ risk and units conversion factor [latent cancer fatalities/rem, latent cancer fatalities/cancer incidence $/\left(\mathrm{kg}_{\text {body mass }}\right.$ - day $\left.)\right]$.

This accident equation is similar to those used in DOE EISs and SARs. The total number of accidents over the time period for the activity is represented by the product $(3 a+3 b)(6)$. The product 
$(1 \mathrm{a})\left(1 \mathrm{a}_{\text {decay }}\right)(2 \mathrm{a})(2 \mathrm{~b})$ represents the $\mathrm{Ci}$ or kg released to the atmosphere from such accidents. Resultant worker and population exposure $\left(\mathrm{mg}_{\text {inhaled }} / \mathrm{kg}_{\text {released }}\right)$ from such releases is modeled by the term $\left(4 * 5 \mathrm{w}_{24-\mathrm{h}}\right.$ $\left.+4 * 5 \mathrm{~s}_{24-\mathrm{h}}+4 * 5 \mathrm{p}_{24-\mathrm{h}}\right)$. The toxicity of such exposures is modeled by the term (1b). Finally, term (7) is used to convert rem to latent cancer fatalities or cancer incidences to cancer fatalities. This accident risk equation is used individually for the actinide and non-actinide groups (for radionuclide releases) and for each chemical of concern.

A portion of Equation (4) can be compared with the airborne source term equation presented in the report Airborne Release Fractions/Rates and Respirable Fractions for Nonreactor Nuclear Facilities (DOE 1994):

Source term $=\quad \mathrm{MAR}^{*} \mathrm{DR} * \mathrm{ARF} * \mathrm{RF} * \mathrm{LPF}$

where Source term $=\quad$ fraction of waste/material released into the atmosphere in respirable form MAR $=$ material at risk (fraction of inventory)

DR $\quad=\quad$ damage ratio (fraction of MAR that is impacted by the accident)

$\mathrm{ARF} \quad=\quad$ airborne release fraction (fraction of MAR $* \mathrm{DR}$ )

$\mathrm{RF} \quad=\quad$ respirable fraction (fraction of MAR*DR*ARF)

$\mathrm{LPF} \quad=\quad$ leak path factor (fraction of MAR*DR*ARF*RF that passes through containment)

In Equation (4), MAR and DR are incorporated into the (3a) and (3b) terms. The (2b) term is comparable to the LPF. Finally, ARF and RF are combined in the (2a) term.

Lookup tables are provided in ESHRAP for most of the accident equation elements. For a given radioactive waste type (Table 3 ), the user only needs to enter the total number of $\mathrm{Ci}$, waste form, and waste volume. ESHRAP then calculates the initial split between actinide and nonactinide Ci [term (1a)] using the actinide fraction (Table 3). Also, given the radioactive waste type, ESHRAP knows which decay curves [term $\left.\left(1 \mathrm{a}_{\text {decay }}\right)\right]$ to use (Figures 3 and 4 ). Radionuclide toxicities [term $\left.(1 \mathrm{~b})\right]$ for these waste and material types are provided as functions of the specific waste type (slope factors in Table 3 ).

Given the waste form, the respirable airborne release fraction is determined from Table 8. Values in Table 8 were estimated using guidance from DOE (1994). However, in that report, the respirable airborne release fractions can vary greatly depending upon the type of material and accident (impact, explosion, fire, etc.). A simplification in ESHRAP is that a single value is used for all of the accidents considered for an activity. Some of the values in Table 8 were not obtained from DOE (1994). For calcine, the respirable fraction is approximately 0.17 (INEEL 2002). Also, values for sludge were chosen to lie between those for powders and cement.

Guidance on the types of accidents to consider and their frequencies and associated MARs and DRs is also provided. The accident frequencies depend upon the design characteristics of the facility being modeled (for natural phenomena) as well as the type of process, adequacy of fire protection, explosive potential of the process and the waste, and other factors (for operational accidents).

A comprehensive list of natural phenomena is presented in NRC (1983). Over 30 different types of events are listed. However, for most facilities, seismic, strong wind, and flooding events are the dominant contributors to risk from natural phenomena. (In some cases, range or forest fires and volcanic events can also be significant.) For simplicity, ESHRAP considers seismic and strong wind events. Range fires can be modeled using the facility fire option under the operational accident category. Flooding events are not modeled as accidents resulting in airborne releases. User options for natural phenomena accidents are presented in Table 9. For facilities located aboveground, both seismic and strong wind events are 
modeled. This implies that the frequency in Table 9 is multiplied by two. For underground facilities, only seismic events are covered.

Table 8. Respirable airborne release fractions for waste forms.

\begin{tabular}{|l|l|l|l|}
\hline \multicolumn{1}{|c|}{ Waste Form } & \multicolumn{1}{c|}{$\begin{array}{c}\text { Airborne Release Fraction } \\
(\mathrm{ARF})\end{array}$} & \multicolumn{1}{|c|}{ Respirable Fraction (RF) } & $\begin{array}{c}\text { Respirable Airborne } \\
\text { Release Fraction (RARF) }\end{array}$ \\
\hline $\begin{array}{l}\text { Gas or vapor from highly } \\
\text { volatile liquid }\end{array}$ & 1.0 & 1.0 & 1.0 \\
\hline Organic solvent & $1.0 \mathrm{E}-1$ & 1.0 & $1.0 \mathrm{E}-1$ \\
\hline Powder & $1.0 \mathrm{E}-2$ & 0.1 & $1.0 \mathrm{E}-3$ \\
\hline Calcine (granular solid) & $4.0 \mathrm{E}-3$ & 0.17 & $6.8 \mathrm{E}-4$ \\
\hline $\begin{array}{l}\text { Loose contamination on } \\
\text { surface of solids }\end{array}$ & $1.0 \mathrm{E}-4$ & 1.0 & $1.0 \mathrm{E}-4$ \\
\hline Sludge & $1.0 \mathrm{E}-3$ & 0.1 & $1.0 \mathrm{E}-4$ \\
\hline Cement, concrete, or grout & $6.0 \mathrm{E}-3$ & 0.01 & $6.0 \mathrm{E}-5$ \\
\hline Low-volatility liquid & $4.0 \mathrm{E}-5$ & 0.7 & $2.8 \mathrm{E}-5$ \\
\hline Glass or ceramic & $1.0 \mathrm{E}-5$ & 0.1 & $1.0 \mathrm{E}-6$ \\
\hline Metal (nonpyrophoric) & $1.0 \mathrm{E}-5$ & 0.1 & $1.0 \mathrm{E}-6$ \\
\hline
\end{tabular}

a. Product of the airborne release fraction and the respirable fraction.

Table 9. Natural phenomena accident options.

\begin{tabular}{|l|l|l|l|l|}
\hline Design Category $^{\mathrm{a}}$ & Frequency $^{\left(\mathrm{y}^{-1}\right)}$ & $\mathrm{MAR}^{\mathrm{b}}$ & $\mathrm{DR}^{\mathrm{c}}$ & $2 \mathrm{~b}(\mathrm{LPF})^{\mathrm{d}}$ \\
\hline Unqualified $^{\mathrm{e}}$ & $1.0 \mathrm{E}-2$ & 1.0 & $0.01(1.0)$ & 1.0 \\
\hline PC1 $(<\mathrm{HC} 3)$ & $2.0 \mathrm{E}-3$ & 1.0 & $0.01(1.0)$ & 0.5 \\
\hline PC2 $(\mathrm{HC} 3)$ & $1.0 \mathrm{E}-3$ & 1.0 & $0.01(1.0)$ & 0.5 \\
\hline PC3 $(\mathrm{HC} 2)$ & $1.0 \mathrm{E}-3$ & 1.0 & $0.01(1.0)$ & 0.1 \\
\hline PC4 $(\mathrm{HC} 1)$ & $2.0 \mathrm{E}-4$ & 1.0 & $0.01(1.0)$ & 0.05 \\
\hline N/A & - & - & - & - \\
\hline
\end{tabular}

a. Performance categories (PC1 through PC4) are defined in DOE (1992a). In general, most facilities used for storage or processing of DOE wastes/materials lie within the PC2 or PC3 category. PC4 is generally used for nuclear reactors, while PC1 is used for facilities with no need to provide containment for the small amounts of wastes/materials stored or processed. Hazard categories (HC1 through HC3) are defined in DOE (1992b).

b. This value is used for storage activities. For handling or processing activities, the user specifies a typical amount of waste/material being handled per activity or being processed per day (number of 55-gallon drums, or equivalent, to be handled or processed).

c. The value in parentheses is for treatment activities, where the MAR is typically a small fraction of the total waste to be processed.

$\mathrm{d}$. The $(2 \mathrm{~b})$ term represents the containment failure probability, given the design basis event. These failure probabilities are specified in DOE (1992a) for each of the performance categories.

e. This design category was added for structures that do not meet natural phenomena design guidelines for the PC1 category.

f. This option is chosen if natural phenomena are to be excluded from the analysis.

Some explanation of the Table 9 entries is necessary. For a PC3 (HC2) facility, the design basis seismic or strong wind event has a frequency of $1.0 \mathrm{E}-3 / \mathrm{y}$. (The magnitude of the design basis event varies by site, but the design addresses the site-specific magnitude.) In a seismic or strong wind event, the amount of waste/material within the facility that is at risk (MAR) is assumed to be 1.0. However, it is also assumed that given the design basis event, only $1 \%$ of the waste/material is actually damaged (DR $=$ 0.01). This value for DR was obtained by reviewing a variety of DOE SARs. Finally, given a PC3 facility category, the value for the $(2 \mathrm{~b})$ term (the performance or failure probability of the containment, or alternatively the LPF) is fixed at 0.1 by the design criteria. 
Detailed seismic or strong wind analyses consider a spectrum of events ranging from frequent but mild to rare beyond design basis. A mild event has a frequency higher than the design basis, but lower DR and ( $2 \mathrm{~b})$ term. The rare beyond design basis event has a frequency lower than the design basis, but higher DR and (2b) term. In ESHRAP, the spectrum of events is approximated by the single design basis event with its associated MAR, DR, and containment failure probability or (2b) term. This simplified approach has been used in DOE SARs and was used to estimate the seismic risk to the public from radionuclide releases from facilities at a DOE site (Durant, Eide, and Shay 1993).

Operational accident options in ESHRAP are presented in Table 10. The accidents modeled for each activity type were chosen based on a review of DOE SARs. The frequency options, MARs, DRs, and containment failure probabilities ( $2 b$ term or LPF) were also chosen based on this review. The ( $2 b)$ term values for container leakage accidents are an order of magnitude lower than for others because this type of accident is not energetic. Descriptive information is provided for each frequency range to assist the analyst in deciding which option is most appropriate. In general, the moderate frequency option is appropriate unless unusual conditions are present.

Several of the activity types might be underground: storage and environmental restoration in-situ treatments. For these activities, the containment failure probabilities in Table 10 are multiplied by the following depth correction factor:

$$
\text { depth correction factor }=[1.0 /(1.0+\text { depth })]^{\mathrm{n}}
$$

where depth correction factor $=$ multiplier on term $(2 \mathrm{~b})$ to account for soil cover above buried waste/material

depth $\quad=\quad$ distance from surface to top of waste $(\mathrm{m})$

$\mathrm{n} \quad=\quad 5.0$ (user can change).

This depth correction factor equation was chosen to result in a negligible containment failure probability (or leak path factor) with respect to atmospheric releases at a depth of five meters, even if the containment structure is assumed to have no strength $(2 b=1.0$, before applying the depth reduction factor).

For waste/material located underground (or where the top of the waste/material is located at the surface), the fraction affected by the accident (natural phenomenon or operational) - DR - is also modified. DR is defined as the factor $(0.1 \mathrm{~m}) /($ thickness of the waste/material in meters). This modification accounts for the accident impacting only the top portion of the waste/material in terms of potential dispersion into the atmosphere. The user can modify the 0.1 -meter assumption.

For facility/activity workers, the term $(2 b)$ used for site workers and the public may not be applicable. ESHRAP has two options for term (2b) for these workers: use the term (2b) as is, or use the square root of the term (2b). This second option is used if not all of the containment applicable for releases to site workers and the public is applicable to the facility/activity workers.

Finally, the atmospheric dispersion and exposure term is a function of the site (for $4 * 5 \mathrm{~s}_{24-\mathrm{h}}$ and $\left.4 * 5 \mathrm{p}_{24-\mathrm{h}}\right)$ or the type and size of the facility (for $\left.4 * 5 \mathrm{w}_{24-\mathrm{h}}\right)$. The exposure terms $\left(4 * 5 \mathrm{~s}_{24-\mathrm{h}}\right)$ and $\left(4 * 5 \mathrm{p}_{24-\mathrm{h}}\right)$ were determined for most of the DOE sites from unit $\mathrm{Ci}$ atmospheric release and exposure calculations performed for the Waste Management Programmatic Environmental Impact Statement (DOE 1997a). These calculations were performed using the GENII atmospheric dispersion code (Napier et al., 1988). 
Table 10. Operational accident options.

\begin{tabular}{|c|c|c|c|c|c|c|}
\hline Activity Type & Accident & $\begin{array}{l}\text { Frequency } \\
\text { Option }\end{array}$ & Frequency $\left(\mathrm{y}^{-1}\right)$ & MAR & DR & $2 b(\mathrm{LPF})$ \\
\hline \multirow[t]{16}{*}{ Storage } & Facility fire & High & $1.0 \mathrm{E}-2$ & 1.0 & 0.1 & 0.01 or 0.1 \\
\hline & & Moderate & $1.0 \mathrm{E}-3$ & 1.0 & 0.1 & 0.01 or 0.1 \\
\hline & & Low & $1.0 \mathrm{E}-4$ & 1.0 & 0.1 & 0.01 or 0.1 \\
\hline & & $\mathrm{N} / \mathrm{A}^{\mathrm{a}}$ & 0.0 & - & - & - \\
\hline & $\begin{array}{l}\text { Facility } \\
\text { explosion }\end{array}$ & High & $1.0 \mathrm{E}-2$ & 1.0 & 0.1 & 0.01 or 0.1 \\
\hline & & Moderate & $1.0 \mathrm{E}-4$ & 1.0 & 0.1 & 0.01 or 0.1 \\
\hline & & Low & $1.0 \mathrm{E}-6$ & 1.0 & 0.1 & 0.01 or 0.1 \\
\hline & & $\mathrm{N} / \mathrm{A}^{\mathrm{a}}$ & 0.0 & - & - & - \\
\hline & $\begin{array}{l}\text { Waste } \\
\text { explosion }\end{array}$ & High & $1.0 \mathrm{E}-2$ & 1.0 & 0.01 & 0.01 or 0.1 \\
\hline & & Moderate & $1.0 \mathrm{E}-4$ & 1.0 & 0.01 & 0.01 or 0.1 \\
\hline & & Low & $1.0 \mathrm{E}-6$ & 1.0 & 0.01 & 0.01 or 0.1 \\
\hline & & $\mathrm{N} / \mathrm{A}^{\mathrm{a}}$ & 0.0 & - & - & - \\
\hline & $\begin{array}{l}\text { Container } \\
\text { leakage }\end{array}$ & High & $1.0 \mathrm{E}-1$ & 1.0 & 0.001 & 0.001 or 0.01 \\
\hline & & Moderate & $1.0 \mathrm{E}-2$ & 1.0 & 0.001 & 0.001 or 0.01 \\
\hline & & Low & $1.0 \mathrm{E}-3$ & 1.0 & 0.001 & 0.001 or 0.01 \\
\hline & & $\mathrm{N} / \mathrm{A}^{\mathrm{a}}$ & 0.0 & - & - & - \\
\hline \multirow[t]{4}{*}{ Handling } & $\begin{array}{l}\text { Drop/ } \\
\text { Puncture }\end{array}$ & High & 1.0 & User input & 1.0 & $\begin{array}{l}0.1 \text { (indoor) or } \\
1.0 \text { (outside) }\end{array}$ \\
\hline & & Moderate & $1.0 \mathrm{E}-1$ & User input & 1.0 & $\begin{array}{l}0.1 \text { (indoor) or } \\
1.0 \text { (outside) }\end{array}$ \\
\hline & & Low & $1.0 \mathrm{E}-2$ & User input & 1.0 & $\begin{array}{l}0.1 \text { (indoor) or } \\
1.0 \text { (outside) }\end{array}$ \\
\hline & & $\mathrm{N} / \mathrm{A}^{\mathrm{a}}$ & 0.0 & - & - & - \\
\hline \multirow[t]{12}{*}{ Treatment } & Process fire & High & $1.0 \mathrm{E}-3$ & User input & 1.0 & 0.01 or 0.1 \\
\hline & & Moderate & $1.0 \mathrm{E}-4$ & User input & 1.0 & 0.01 or 0.1 \\
\hline & & Low & $1.0 \mathrm{E}-5$ & User input & 1.0 & 0.01 or 0.1 \\
\hline & & $\mathrm{N} / \mathrm{A}^{\mathrm{a}}$ & 0.0 & - & - & - \\
\hline & $\begin{array}{l}\text { Process } \\
\text { explosion }\end{array}$ & High & $1.0 \mathrm{E}-2$ & User input & 1.0 & 0.01 or 0.1 \\
\hline & & Moderate & $1.0 \mathrm{E}-4$ & User input & 1.0 & 0.01 or 0.1 \\
\hline & & Low & $1.0 \mathrm{E}-6$ & User input & 1.0 & 0.01 or 0.1 \\
\hline & & $\mathrm{N} / \mathrm{A}^{\mathrm{a}}$ & 0.0 & - & - & - \\
\hline & $\begin{array}{l}\text { Process } \\
\text { criticality }\end{array}$ & High & $1.0 \mathrm{E}-3$ & User input & 1.0 & 0.01 or 0.1 \\
\hline & & Moderate & $1.0 \mathrm{E}-5$ & User input & 1.0 & 0.01 or 0.1 \\
\hline & & Low & $1.0 \mathrm{E}-7$ & User input & 1.0 & 0.01 or 0.1 \\
\hline & & $\mathrm{N} / \mathrm{A}^{\mathrm{a}}$ & 0.0 & - & - & - \\
\hline \multirow{2}{*}{ Transportation } & Collision $^{\mathrm{b}}$ & & & & & \\
\hline & $\begin{array}{l}\text { Pipe transfer } \\
\text { accident }^{c}\end{array}$ & & & & & \\
\hline Disposal & $\begin{array}{l}\text { Natural } \\
\text { Phenomena and } \\
\text { Intrusion }^{\mathrm{d}}\end{array}$ & & & & & \\
\hline
\end{tabular}

a. This option is chosen if the accident type is to be excluded from the analysis.

b. Transportation accidents are discussed in Section 3.9.

c. Pipe transfer accidents are similar to treatment accidents.

d. Disposal scenarios are discussed in Section 3.10. 
For exposure to the public $\left(4 * 5 \mathrm{p}_{24-\mathrm{h}}\right.$ term), DOE (1997a) considered the population distribution surrounding a DOE site up to $80 \mathrm{~km}(50 \mathrm{mi})$. Populations were obtained from the 1990 U.S. census data. Exposure to the public was determined using 95\% atmospheric conditions for accidental releases (24-hour release modeled) and 50\% atmospheric conditions for chronic releases (one-year release modeled). Exposure included internal exposure from inhaled radionuclides and exposure from ingestion of crops and livestock. Results were presented in terms of total person-rem (committed dose), assuming a release of $1 \mathrm{Ci}$ of a given radionuclide. To estimate the term $\left(4 * 5 \mathrm{p}_{24-\mathrm{h}}\right)$, the results for a radionuclide were divided by the inhalation dose conversion factor for that radionuclide.

For example, the GENII population exposure for the INEEL (24-hour release of $1 \mathrm{Ci}$ of Pu-239) from internal exposure is 1620 person-rem $/ \mathrm{Ci}_{\text {released. }}$ Dividing this result by the inhalation dose conversion factor $(330 \mathrm{rem} / \mu \mathrm{Ci}$ inhaled $)$ results in $4.9 \mu \mathrm{Ci}$ inhaled $/ \mathrm{Ci}_{\text {released }}$ for the INEEL for term $\left(4 * 5 \mathrm{p}_{24-\mathrm{h}}\right)$. Similarly, the GENII population exposure for the INEEL (one-year release of $1 \mathrm{Ci}$ of $\mathrm{Pu}-239$ ) is 7.96 person$\mathrm{rem} / \mathrm{Ci}$ released, which converts to $0.024 \mu \mathrm{Ci}_{\text {inhaled }} / \mathrm{Ci}_{\text {released. }}$. This is the value for the term $\left(4 * 5 \mathrm{p}_{1-\mathrm{y}}\right)$, which is discussed in Section 3.7.] This approach effectively incorporates the dose from crop and livestock ingestion into the inhalation calculation. It should be noted that in general the dose from crop and livestock ingestion was less than $10 \%$ of the dose from only inhalation. Results for the terms $\left(4 * 5 \mathrm{p}_{24-\mathrm{h}}\right)$ and $\left(4 * 5 p_{1-y}\right)$ for various DOE sites are presented in Table 11 .

A comparison of the INEEL term $\left(4 * 5 \mathrm{p}_{24-\mathrm{h}}\right)$ with results from a Gaussian plume model using Pasquill-Gifford coefficients (Eide et al. 1996) is presented in Table 12. To compute the term (4*5p 24 -h), the following equation is used:

$$
\left(4 * 5 \mathrm{p}_{24-\mathrm{h}}\right)=\quad \sum\left(\mathrm{P}_{\mathrm{i}}\right)(\Pi / \mathrm{Q})_{\mathrm{i}}(\mathrm{BR})(\mathrm{UC})
$$

where $\left(4 * 5 \mathrm{p}_{24-\mathrm{h}}\right)=\quad$ unit $\mathrm{Ci}$ or $\mathrm{kg}$ exposure to population within $80 \mathrm{~km}(50 \mathrm{mi})$ resulting from

$$
\begin{array}{lll}
\mathrm{P}_{\mathrm{i}} & = & \text { population within distance interval } \mathrm{i} \\
\Pi / \mathrm{Q}_{\mathrm{i}} & = & \text { dispersion coefficient }\left(\mathrm{s} / \mathrm{m}^{3}\right) \text { for interval } \mathrm{i} \\
\mathrm{BR} & = & \text { EPA mean breathing rate }\left(\mathrm{m}^{3} / \mathrm{s}\right) \\
\mathrm{UC} & = & \text { units conversion }\left(1 \mathrm{E}+6 \mu \mathrm{Ci} \mathrm{i}_{\text {inhaled }} / \mathrm{Ci}_{\text {released }}\right) .
\end{array}
$$

Results for stability classes A through $\mathrm{F}$ are presented in Table 12. The GENII result of 4.9 (including a small contribution from crop and livestock ingestion) is close to the Gaussian plume result using stability class E.

A conversion factor is also applied to each site 24 -hour release term $\left(4 * 5 \mathrm{p}_{24-\mathrm{h}}\right)$ to reduce the $95 \%$ result to a mean value. This multiplier is roughly 0.25 , based on the Gaussian plume model results presented in Table 12. The 95\% results agree well with the Gaussian plume model results for stability class E. A mean value is assumed to correspond to stability class C. Therefore, from Table 12 the stability class $C$ result divided by the stability class $E$ result is $1.37 / 5.61=0.24$, which is rounded to 0.25 .

Finally, ESHRAP has the option to model population increases with time. The user can specify an annual percentage increase in the offsite population with an end date beyond which the offsite population is assumed to remain constant. This percentage increase is assumed to apply to the populations within each of the distance intervals in Table 12 , so the terms $\left(4 * 5 \mathrm{p}_{24-\mathrm{h}}\right)$ and $\left(4 * 5 \mathrm{p}_{1-\mathrm{y}}\right)$ increase linearly with the population increase. 
Table 11. Atmospheric dispersion and exposure terms $(4 * 5 \mathrm{p}$ and $4 * 5 \mathrm{~s})$ for DOE sites.

\begin{tabular}{|c|c|c|c|c|c|c|}
\hline DOE Site & $\begin{array}{l}\text { Offsite } \\
\text { Population } \\
\text { within } 80 \mathrm{~km} \\
(50 \mathrm{mi}) \\
(1990)\end{array}$ & $\begin{array}{l}4 * 5 p_{24-h}(24- \\
\text { hour release }) \\
\left(\mu C i_{\text {inhaled }} /\right. \\
\left.C i_{\text {released }}\right)\end{array}$ & $\begin{array}{l}4 * 5 \mathrm{p}_{1-\mathrm{y}}(1- \\
\text { year release }) \\
\left(\mu \mathrm{Ci}_{\text {inhaled }} /\right. \\
\left.\mathrm{Ci}_{\text {released }}\right)\end{array}$ & $\begin{array}{l}\text { Onsite } \\
\text { Population } \\
(2000)^{\mathrm{a}}\end{array}$ & $\begin{array}{l}4 * 5 \mathrm{~s}_{24-\mathrm{h}}(24- \\
\text { hour release }) \\
\left(\mu \mathrm{Ci}_{\text {inhaled }} /\right. \\
\left.\mathrm{Ci}_{\text {released }}\right)^{\mathrm{a}}\end{array}$ & $\begin{array}{l}4 * 5 s_{1-y}(1- \\
\text { year release }) \\
\left(\mu C i_{\text {inhaled }} /\right. \\
\left.C i_{\text {released }}\right)^{a}\end{array}$ \\
\hline ANL-East & $7.9 \mathrm{E}+06$ & $3.6 \mathrm{E}+02$ & $1.0 \mathrm{E}+01$ & $3.9 \mathrm{E}+03$ & $5.8 \mathrm{E}-01$ & $1.6 \mathrm{E}-02$ \\
\hline BNL & $5.7 \mathrm{E}+06$ & $1.0 \mathrm{E}+03$ & $4.4 \mathrm{E}+00$ & $3.2 \mathrm{E}+03$ & $1.1 \mathrm{E}+00$ & $2.0 \mathrm{E}-02$ \\
\hline Envirocare $^{b}$ & $0.0 \mathrm{E}+00$ & $0.0 \mathrm{E}+00$ & $0.0 \mathrm{E}+00$ & $3.0 \mathrm{E}+02$ & $6.0 \mathrm{E}-02$ & $7.5 \mathrm{E}-04$ \\
\hline ETEC & $1.0 \mathrm{E}+07$ & $1.0 \mathrm{E}+03$ & $1.0 \mathrm{E}+01$ & $7.1 \mathrm{E}+01$ & $2.1 \mathrm{E}-02$ & $4.9 \mathrm{E}-04$ \\
\hline ETTP (K-25) & $8.7 \mathrm{E}+05$ & $8.9 \mathrm{E}+01$ & $1.3 \mathrm{E}+00$ & $2.6 \mathrm{E}+03$ & $1.2 \mathrm{E}+00$ & $3.0 \mathrm{E}-02$ \\
\hline FEMP & $2.8 \mathrm{E}+06$ & $3.5 \mathrm{E}+02$ & $1.0 \mathrm{E}+01$ & $2.3 \mathrm{E}+03$ & $1.3 \mathrm{E}+00$ & $2.4 \mathrm{E}-02$ \\
\hline Hanford & $3.8 \mathrm{E}+05$ & $8.7 \mathrm{E}+01$ & $7.1 \mathrm{E}-01$ & $1.1 \mathrm{E}+04$ & $5.5 \mathrm{E}+00$ & $7.8 \mathrm{E}-02$ \\
\hline INEEL & $1.5 \mathrm{E}+05$ & $4.9 \mathrm{E}+00$ & $2.4 \mathrm{E}-02$ & $8.4 \mathrm{E}+03$ & $2.5 \mathrm{E}+00$ & $4.0 \mathrm{E}-03$ \\
\hline KAPL-K & $1.3 \mathrm{E}+06$ & $1.0 \mathrm{E}+02$ & $4.9 \mathrm{E}+00$ & $3.1 \mathrm{E}+03$ & $9.6 \mathrm{E}-01$ & $2.6 \mathrm{E}-02$ \\
\hline KCP & $1.7 \mathrm{E}+06$ & $9.2 \mathrm{E}+01$ & $4.5 \mathrm{E}+00$ & $2.9 \mathrm{E}+03$ & $6.6 \mathrm{E}-01$ & $1.8 \mathrm{E}-02$ \\
\hline LANL & $1.6 \mathrm{E}+05$ & $3.0 \mathrm{E}+01$ & $7.2 \mathrm{E}-01$ & $1.1 \mathrm{E}+04$ & $2.3 \mathrm{E}+00$ & $6.3 \mathrm{E}-02$ \\
\hline LBL & $5.9 \mathrm{E}+06$ & $5.6 \mathrm{E}+02$ & $1.1 \mathrm{E}+01$ & $3.3 \mathrm{E}+03$ & $2.2 \mathrm{E}+00$ & $3.1 \mathrm{E}-02$ \\
\hline LLNL & $6.3 \mathrm{E}+06$ & $4.7 \mathrm{E}+02$ & $4.2 \mathrm{E}+00$ & $8.5 \mathrm{E}+03$ & $3.8 \mathrm{E}+00$ & $8.9 \mathrm{E}-02$ \\
\hline Mound & $3.0 \mathrm{E}+06$ & $2.4 \mathrm{E}+02$ & $5.0 \mathrm{E}+00$ & $9.8 \mathrm{E}+02$ & $3.0 \mathrm{E}-01$ & $1.1 \mathrm{E}-02$ \\
\hline MSP & $1.7 \mathrm{E}+07$ & $1.5 \mathrm{E}+03$ & $1.8 \mathrm{E}+01$ & $0.0 \mathrm{E}+00$ & $0.0 \mathrm{E}+00$ & $0.0 \mathrm{E}+00$ \\
\hline NTS & $1.4 \mathrm{E}+04$ & $1.4 \mathrm{E}+00$ & $6.9 \mathrm{E}-03$ & $1.5 \mathrm{E}+03$ & $3.1 \mathrm{E}-01$ & $4.6 \mathrm{E}-03$ \\
\hline ORNL & $8.8 \mathrm{E}+05$ & $1.2 \mathrm{E}+02$ & $1.7 \mathrm{E}+00$ & $4.1 \mathrm{E}+03$ & $1.1 \mathrm{E}+01$ & $5.6 \mathrm{E}-02$ \\
\hline Pantex & $2.7 \mathrm{E}+05$ & $2.8 \mathrm{E}+01$ & $9.0 \mathrm{E}-02$ & $3.0 \mathrm{E}+03$ & $3.2 \mathrm{E}-01$ & $9.6 \mathrm{E}-03$ \\
\hline PGDP $^{\mathrm{c}}$ & $5.0 \mathrm{E}+05$ & $3.8 \mathrm{E}+01$ & $4.9 \mathrm{E}-01$ & $2.0 \mathrm{E}+03$ & 7.9E-01 & $2.1 \mathrm{E}-02$ \\
\hline Pinellas $^{c}$ & $2.5 \mathrm{E}+06$ & $2.0 \mathrm{E}+02$ & $4.6 \mathrm{E}+00$ & $1.2 \mathrm{E}+03$ & $2.4 \mathrm{E}-01$ & $9.0 \mathrm{E}-03$ \\
\hline Portsmouth $^{\mathrm{c}}$ & $6.4 \mathrm{E}+05$ & $3.5 \mathrm{E}+01$ & $7.8 \mathrm{E}-01$ & $3.2 \mathrm{E}+03$ & $2.8 \mathrm{E}+00$ & $1.0 \mathrm{E}-01$ \\
\hline RFETS & $2.2 \mathrm{E}+06$ & $1.8 \mathrm{E}+02$ & $2.5 \mathrm{E}+00$ & $5.4 \mathrm{E}+03$ & $1.3 \mathrm{E}+00$ & $3.9 \mathrm{E}-02$ \\
\hline SNL-NM & $6.1 \mathrm{E}+05$ & $1.1 \mathrm{E}+02$ & $3.3 \mathrm{E}+00$ & $8.8 \mathrm{E}+03$ & $2.4 \mathrm{E}+00$ & $5.6 \mathrm{E}-02$ \\
\hline SRS & $6.2 \mathrm{E}+05$ & $2.8 \mathrm{E}+01$ & $4.2 \mathrm{E}-01$ & $1.5 \mathrm{E}+04$ & $5.6 \mathrm{E}+00$ & $3.7 \mathrm{E}-02$ \\
\hline WIPP & $1.0 \mathrm{E}+05$ & $1.8 \mathrm{E}+01$ & $5.6 \mathrm{E}-02$ & $7.8 \mathrm{E}+02$ & $1.5 \mathrm{E}-01$ & $1.9 \mathrm{E}-03$ \\
\hline WVDP & $1.7 \mathrm{E}+06$ & $2.4 \mathrm{E}+02$ & $4.2 \mathrm{E}+00$ & $1.1 \mathrm{E}+03$ & $3.4 \mathrm{E}+00$ & $8.5 \mathrm{E}-03$ \\
\hline Y-12 & $9.0 \mathrm{E}+05$ & $9.0 \mathrm{E}+01$ & $1.5 \mathrm{E}+00$ & $5.3 \mathrm{E}+03$ & $2.5 \mathrm{E}+00$ & $7.5 \mathrm{E}-02$ \\
\hline Yucca Mt. & $1.4 \mathrm{E}+04$ & $1.4 \mathrm{E}+00$ & $6.9 \mathrm{E}-03$ & $1.9 \mathrm{E}+03$ & $4.2 \mathrm{E}-01$ & $6.1 \mathrm{E}-03$ \\
\hline
\end{tabular}

Acronyms: ANL-Argonne National Laboratory, BNL - Brookhaven National Laboratory, ETEC - Energy

Technology Engineering Center, ETTP - East Tennessee Technology Park, FEMP - Fernald Environmental Management Project, INEEL - Idaho National Engineering and Environmental Laboratory, KAPL-K - Knolls Atomic Power Laboratory - Kesselring, KCP - Kansas City Plant, LANL - Los Alamos National Laboratory, LBL - Lawrence Berkeley Laboratory, LLNL - Lawrence Livermore National Laboratory, MDP - Middlesox Sampling Plant, NTS - Nevada Test Station, ORNL - Oak Ridge National Laboratory, PGDP - Paducah Gaseous Diffusion Plant, RFETS - Rocky Flats Environmental Technology Site, SNL-NM - Sandia National Laboratory - New Mexico, SRS - Savannah River Site, WIPP - Waste Isolation Pilot Plant, WVDP - West Valley Demonstration Project

a. Year 2000 estimates obtained from DOE CAIRS total hours data, assuming 1850 hours/year for a worker. $4 * 5 \mathrm{~s}$ values (DOE 1997a) modified to account for year 2000 site population by multiplying the $4 * 5$ s value by the ratio "year 2000 site population/site population in DOE 1997a."

b. Estimated from Envirocare information (Envirocare 2003).

c. Year 2000 estimates not available.

d. NTS information used.

For exposure to site workers $\left(4 * 5 s_{24-h}\right.$ term), the worker populations at DOE sites were used. The site worker population estimates for the year 2000 were estimated using DOE worker hour information from the Computerized Accident/Injury Reporting System (CAIRS) database, assuming 1850 worker hours per year (DOE 2001b). Exposure to the site workers was determined using 95\% atmospheric 
conditions for accidental releases (24-hour release modeled) and 50\% atmospheric conditions for chronic releases (one-year release modeled). Exposure included only internal exposure from inhaled radionuclides. (Exposure from ingestion of crops and livestock was not included.) Also, it was assumed that the site workers would be present only eight hours of each day. Results were presented in terms of total person-rem (committed dose), assuming a release of $1 \mathrm{Ci}$ of a given radionuclide. To estimate the $\left(4 * 5 \mathrm{~s}_{24-\mathrm{h}}\right)$ term, the results for a radionuclide were divided by the inhalation dose conversion factor for that radionuclide. Results for each DOE site are presented in Table 11. Similar to the (4*5p) terms, a sitespecific multiplier is used to reduce the $95 \%$ dispersion results to mean results. This multiplier is roughly 0.25 .

Table 12. Evaluation of term $\left(4 * 5 \mathrm{p}_{24-\mathrm{h}}\right)$ for INEEL using Gaussian plume model.

\begin{tabular}{|c|c|c|c|c|c|c|c|c|}
\hline & \multicolumn{6}{|c|}{ Distance Interval $(\mathrm{km})$} & \multirow{2}{*}{$\begin{array}{c}\begin{array}{c}\text { Summation } \\
\text { of Interval } \\
\text { Results }^{\text {a }}\end{array} \\
0-80\end{array}$} & \multirow{2}{*}{$\begin{array}{l}\text { GENII } \\
\text { Result }^{\mathrm{b}}\end{array}$} \\
\hline & $0-8$ & $8-16$ & $16-32$ & $32-48$ & $48-64$ & $64-80$ & & \\
\hline Population & 0 & 26 & 349 & 5324 & 42934 & 104428 & 153061 & \\
\hline $\begin{array}{c}\text { Average } \\
\text { Distance } \\
(\mathrm{km})\end{array}$ & 4 & 12 & 24 & 40 & 56 & 72 & - & \\
\hline $\begin{array}{c}\text { П/Q Class A } \\
\left(\mathrm{s} / \mathrm{m}^{3}\right)\end{array}$ & $3.0 \mathrm{E}-7$ & $1.0 \mathrm{E}-7$ & $5.5 \mathrm{E}-8$ & $3.7 \mathrm{E}-8$ & $2.5 \mathrm{E}-8$ & $2.1 \mathrm{E}-8$ & - & \\
\hline $\begin{array}{l}\mathrm{Ci}_{\text {inhaled }} / \\
\mathrm{Ci}_{\text {released }} \\
\text { Class A }\end{array}$ & $0.0 \mathrm{E}+0$ & $6.0 \mathrm{E}-10$ & $4.4 \mathrm{E}-9$ & $4.5 \mathrm{E}-8$ & $2.5 \mathrm{E}-7$ & $5.0 \mathrm{E}-7$ & 0.80 & 4.9 \\
\hline $\begin{array}{c}\text { П/Q Class В } \\
\left(\mathrm{s} / \mathrm{m}^{3}\right)\end{array}$ & $4.8 \mathrm{E}-7$ & $1.4 \mathrm{E}-7$ & $7.3 \mathrm{E}-8$ & $4.9 \mathrm{E}-8$ & $3.2 \mathrm{E}-8$ & $2.9 \mathrm{E}-8$ & - & \\
\hline $\begin{array}{l}\mathrm{Ci}_{\text {inhaled }} / \\
\mathrm{Ci}_{\text {ireleased }} \\
\text { Class B }\end{array}$ & $0.0 \mathrm{E}+0$ & $8.4 \mathrm{E}-10$ & $5.9 \mathrm{E}-9$ & $6.0 \mathrm{E}-8$ & $3.2 \mathrm{E}-7$ & $7.0 \mathrm{E}-7$ & 1.08 & 4.9 \\
\hline $\begin{array}{c}\text { П/Q Class C } \\
\left(\mathrm{s} / \mathrm{m}^{3}\right)\end{array}$ & $1.1 \mathrm{E}-6$ & $1.7 \mathrm{E}-7$ & $9.3 \mathrm{E}-8$ & $6.3 \mathrm{E}-8$ & $4.2 \mathrm{E}-8$ & $3.6 \mathrm{E}-8$ & - & \\
\hline $\begin{array}{l}\mathrm{Ci}_{\text {inhaled }} / \\
\mathrm{Ci}_{\text {ireleased }} \\
\text { Class C }\end{array}$ & $0.0 \mathrm{E}+0$ & $1.0 \mathrm{E}-9$ & $7.5 \mathrm{E}-9$ & $7.7 \mathrm{E}-8$ & $4.1 \mathrm{E}-7$ & $8.6 \mathrm{E}-7$ & 1.37 & 4.9 \\
\hline $\begin{array}{c}\text { П/Q Class D } \\
\left(\mathrm{s} / \mathrm{m}^{3}\right)\end{array}$ & $3.7 \mathrm{E}-6$ & $5.8 \mathrm{E}-7$ & $2.2 \mathrm{E}-7$ & $1.3 \mathrm{E}-7$ & $6.6 \mathrm{E}-8$ & $5.5 \mathrm{E}-8$ & - & \\
\hline $\begin{array}{l}\mathrm{Ci}_{\text {inhaled }} / \\
\mathrm{Ci}_{\text {ireleased }} \\
\text { Class D }\end{array}$ & $0.0 \mathrm{E}+0$ & $3.5 \mathrm{E}-9$ & $1.8 \mathrm{E}-8$ & $1.6 \mathrm{E}-7$ & $6.5 \mathrm{E}-7$ & $1.3 \mathrm{E}-6$ & 2.15 & 4.9 \\
\hline $\begin{array}{c}\text { П/Q Class E } \\
\left(\mathrm{s} / \mathrm{m}^{3}\right)\end{array}$ & $7.7 \mathrm{E}-6$ & $1.4 \mathrm{E}-6$ & $5.8 \mathrm{E}-7$ & $3.4 \mathrm{E}-7$ & $1.8 \mathrm{E}-7$ & $1.4 \mathrm{E}-7$ & - & \\
\hline $\begin{array}{l}\mathrm{Ci}_{\text {inhaled }} / \\
\mathrm{Ci}_{\text {ireleased }} \\
\text { Class E }\end{array}$ & $0.0 \mathrm{E}+0$ & $8.4 \mathrm{E}-9$ & $4.7 \mathrm{E}-8$ & $4.2 \mathrm{E}-7$ & $1.8 \mathrm{E}-6$ & $3.4 \mathrm{E}-6$ & 5.61 & 4.9 \\
\hline $\begin{array}{c}\text { П/Q Class F } \\
\left(\mathrm{s} / \mathrm{m}^{3}\right)\end{array}$ & $1.8 \mathrm{E}-5$ & $3.4 \mathrm{E}-6$ & $1.5 \mathrm{E}-7$ & $8.9 \mathrm{E}-7$ & $5.0 \mathrm{E}-7$ & $4.1 \mathrm{E}-7$ & - & \\
\hline $\begin{array}{l}\mathrm{Ci}_{\text {inhaled }} \\
\mathrm{Ci}_{\text {ireleased }} \\
\text { Class F }\end{array}$ & $0.0 \mathrm{E}+0$ & $2.0 \mathrm{E}-8$ & $1.2 \mathrm{E}-8$ & $1.1 \mathrm{E}-6$ & $4.9 \mathrm{E}-6$ & $9.8 \mathrm{E}-6$ & 15.9 & 4.9 \\
\hline
\end{tabular}

a. Multiplied by $1 \mathrm{E}+6 \mu \mathrm{Ci} / \mathrm{Ci}$.

b. GENII analysis assumed $95 \%$ meteorological conditions.

c. Breathing rate of $2.3 \mathrm{E}-4 \mathrm{~m}^{3} / \mathrm{s}$ assumed (EPA 1989)

The final atmospheric dispersion and exposure term covers the workers associated with the activity being analyzed $\left(4 * 5 \mathrm{w}_{24-\mathrm{h}}\right)$. Workers associated with the activity are broken down into three locations: one meter from the release point, 10 meters from the release point, and 100 meters from the release point. Atmospheric dispersion codes such as GENII typically are not designed to predict atmospheric concentrations of contaminants for distances closer than approximately $100 \mathrm{~m}$ from the release location. Therefore, other ways are needed to estimate worker exposure. In DOE (1997a), a hemisphere model is described for use in calculating worker exposures to accidental releases to the atmosphere. A five-meter 
radius hemisphere is assumed, and a worker assumed to be located one meter from the source walks away at a speed of one meter/second. Therefore, that worker is exposed to contaminated air (within the fivemeter radius hemisphere) for four seconds. The concentration within the hemisphere is assumed to be uniform, based on the amount of released contaminant and the volume of the hemisphere.

A similar type of model is used in ESHRAP for the workers located one meter and 10 meters from the release point. For workers located one meter away, the atmospheric concentration is based on a release into a $1.0 \mathrm{E}+3 \mathrm{~m}^{3}$ volume. Also, those workers take 10 seconds to retreat to a location of 10 meters. Assuming a $1 \mathrm{Ci}$ release and using the EPA 95\% breathing rate (the workers are excited), the exposure per worker is the following:

$$
\begin{aligned}
\operatorname{Exp}_{1-\mathrm{m}} & =\left(1 \mathrm{Ci} / 1 \mathrm{E}+3 \mathrm{~m}^{3}\right)\left(3.5 \mathrm{E}-4 \mathrm{~m}^{3} / \mathrm{s}\right)(1 \mathrm{E}+6 \mu \mathrm{Ci} / \mathrm{Ci})(10 \mathrm{~s}) \\
& =3.5 \mu \mathrm{Ci} \mathrm{i}_{\text {inhaled }} / \mathrm{Ci}_{\text {released }} \text { worker. }
\end{aligned}
$$

For workers located 10 meters away, the atmospheric concentration is based on a release into a volume of $8.0 \mathrm{E}+3 \mathrm{~m}^{3}$. Those workers (including those originally located at one meter) take one minute to evacuate to a location of $100 \mathrm{~m}$. The exposure for these workers while at the 10-meter location is the following:

$$
\begin{aligned}
\operatorname{Exp}_{10-\mathrm{m}} & =\left(1 \mathrm{Ci} / 8 \mathrm{E}+3 \mathrm{~m}^{3}\right)\left(3.5 \mathrm{E}-4 \mathrm{~m}^{3} / \mathrm{s}\right)(1 \mathrm{E}+6 \mu \mathrm{Ci} / \mathrm{Ci})(60 \mathrm{~s}) \\
& =2.6 \mu \mathrm{Ci}_{\text {inhaled }} / \mathrm{Ci}_{\text {released }} \text { worker. }
\end{aligned}
$$

Finally, for workers located 100 meters away, the Gaussian plume atmospheric dispersion results (stability class E) are used (Eide et al. 1996). It is assumed these workers require one hour to evacuate and their breathing rate is average. Therefore, their exposure is the following:

$$
\begin{aligned}
\operatorname{Exp}_{100-\mathrm{m}} & =(2.3 \mathrm{E}-3)\left(2.3 \mathrm{E}-4 \mathrm{~m}^{3} / \mathrm{s}\right)(1 \mathrm{E}+6 \mu \mathrm{Ci} / \mathrm{Ci})(1 \mathrm{~h} / 24 \mathrm{~h}) \\
& =0.022 \mu \mathrm{Ci}_{\text {inhaled }} / \mathrm{Ci}_{\text {released }} \text {-worker. }
\end{aligned}
$$

Combining this information, the ESHRAP $(4 * 5 \mathrm{w})$ term is calculated using the following equation:

$$
\left(4 * 5 \mathrm{w}_{24-\mathrm{h}}\right)=\quad\left[(\mathrm{X})^{0.5}(\mathrm{Z})\left(\operatorname{Exp}_{1-\mathrm{m}}\right)+(\mathrm{X})\left(\operatorname{Exp}_{10-\mathrm{m}}\right)+(\mathrm{X}+\mathrm{Y})\left(\operatorname{Exp}_{100-\mathrm{m}}\right)\right] / 3
$$

where $\left(4 * 5 \mathrm{w}_{24-\mathrm{h}}\right)=\quad$ unit $\mathrm{Ci}$ or $\mathrm{kg}$ exposure to facility workers resulting from atmospheric dispersion

$$
\begin{array}{lll}
\mathrm{X} & = & \text { and inhalation }\left(\mu \mathrm{Ci}_{\text {inhaled }} / \mathrm{Ci}_{\text {released }} \text { or } \mathrm{mg}_{\text {inhaled }} / \mathrm{kg}_{\text {released }}\right) \\
\mathrm{Y} & = & \text { number of involved workers for activity } \\
\mathrm{Z} & = & \text { fraction of time involved workers are near the waste/material during their shift. }
\end{array}
$$

It is assumed that only a fraction of the involved workers will be one meter from the waste/material. The term $(\mathrm{X})^{0.5}$ is used to approximate the number of involved workers at one meter. Also, the division by three accounts for the workers being at the facility/activity only one shift per day. For processing activities in which the accidents occur mainly during operation, the division by three is not applicable. Results for representative large facilities/activities are presented in Table 13. Values for other sizes of facilities/activities are estimated by applying the factor (volume/volume large facility $^{0.33}$ used in Equations (1) and (2).

The final term (7) in Equation (4) is a risk and units conversion factor. For radionuclide releases, the units for Equation (4) are the following:

$$
\text { Risk }=[1 \mathrm{a}(\mathrm{Ci})]\left[1 \mathrm{~b}\left(\mathrm{rem} / \mu \mathrm{Ci} \mathrm{i}_{\text {inhaled }}\right)\right][2 \mathrm{a}][2 \mathrm{~b}]\left[3\left(\mathrm{y}^{-1}\right)\right]\left[4 * 5\left(\mu \mathrm{Ci}_{\text {inhaled }} / \mathrm{Ci}_{\text {released }}\right)\right]
$$


In order for the risk in Equation (4) to be in terms of fatalities, term (7) must be a conversion from rem to latent cancer fatalities. This conversion factor is 5.0E-4 latent cancer fatalities/rem for the public and 4.0E-4 for site and facility/activity workers (DOE 1997a). If desired, the user can account for advances in the prevention and treatment of cancer by specifying a yearly percentage drop in the cancer death/rem rates for workers and the public and an end date beyond which the rates are assumed to remain constant.

Table 13. Term $\left(4 * 5 \mathrm{w}_{24-\mathrm{h}}\right)$ for large facilities/activities.

\begin{tabular}{|c|c|c|c|c|c|c|}
\hline $\begin{array}{l}\text { Activity } \\
\text { Category }\end{array}$ & Activity Type & Activity & $\begin{array}{c}\text { Number of } \\
\text { Involved } \\
\text { Workers }(\mathrm{X})\end{array}$ & $\begin{array}{c}\text { Number of } \\
\text { Support } \\
\text { Personnel (Y) }\end{array}$ & $\begin{array}{c}\text { Fraction of } \\
\text { Time } \\
\text { Involved } \\
\text { Worker is } \\
\text { Near Waste/ } \\
\text { Material (Z) }\end{array}$ & $\begin{array}{c}4 * 5 \mathrm{w}_{24-\mathrm{h}} \\
\left(\mu \mathrm{C \textrm {i } _ { \text { inhaled } }} /\right. \\
\left.\mathrm{Ci}_{\text {released }}\right)\end{array}$ \\
\hline \multirow[t]{15}{*}{$\begin{array}{l}\text { Waste/Material } \\
\text { Management }\end{array}$} & $\begin{array}{l}\text { Storage } \\
\text { (Aboveground) }\end{array}$ & Building, Tank & 3 & 3 & 0.125 & 2.9 \\
\hline & & Berm & 1.5 & 1.5 & 0.062 & 1.4 \\
\hline & $\begin{array}{l}\text { Storage } \\
\text { (Belowground) }\end{array}$ & $\begin{array}{l}\text { Vault, Trench, } \\
\text { Tank }\end{array}$ & 1.5 & 1.5 & 0.062 & 1.4 \\
\hline & Handling & All & 25 & 25 & 0.5 & 74.9 \\
\hline & Treatment & Certification & 5 & 5 & 0.5 & 17.1 \\
\hline & & Venting & 10 & 10 & 0.5 & 32.0 \\
\hline & & Sort/Repackage & 50 & 50 & 0.5 & 145. \\
\hline & & $\begin{array}{l}\text { Waste } \\
\text { Preparation }\end{array}$ & 20 & 20 & 0.5 & 60.7 \\
\hline & & Low Energy & 15 & 15 & 0.5 & 46.4 \\
\hline & & Moderate Energy & 35 & 35 & 0.5 & 103. \\
\hline & & High Energy & 35 & 35 & 0.5 & 103. \\
\hline & Transportation & Truck & 2 & 0 & 1.0 & 10.2 \\
\hline & & Rail & 2 & 0 & 1.0 & 10.2 \\
\hline & & Pipe & 5 & 5 & 0.5 & 17.1 \\
\hline & Disposal & All & 2 & 2 & 0.062 & 1.9 \\
\hline \multirow{6}{*}{$\begin{array}{l}\text { Environmental } \\
\text { Restoration }\end{array}$} & Capping & Capping & 15 & 15 & 0.5 & 46.4 \\
\hline & In-situ treatment & $\begin{array}{l}\text { Low energy } \\
\text { (grouting) }\end{array}$ & 10 & 10 & 0.25 & 29.2 \\
\hline & & Moderate energy & 10 & 10 & 0.25 & 29.2 \\
\hline & & $\begin{array}{l}\text { High energy } \\
\text { (thermal } \\
\text { desorption, } \\
\text { vitrification) }\end{array}$ & 10 & 10 & 0.25 & 29.2 \\
\hline & Extraction & $\begin{array}{l}\text { Vapor vacuum } \\
\text { extraction }\end{array}$ & 5 & 5 & 0.125 & 14.2 \\
\hline & & Pump and treat & 5 & 5 & 0.125 & 14.2 \\
\hline \multirow[t]{3}{*}{ D\&D } & Characterization & Characterization & 5 & 5 & 0.5 & 17.1 \\
\hline & $\begin{array}{l}\text { Surveillance/ } \\
\text { Maintenance }\end{array}$ & $\begin{array}{l}\text { Surveillance and } \\
\text { maintenance }\end{array}$ & 0.5 & 0.5 & 0.125 & 0.5 \\
\hline & Other & Other & 15 & 15 & 0.5 & 46.5 \\
\hline \multirow[t]{2}{*}{$\begin{array}{l}\text { Long-Term } \\
\text { Stewardship }\end{array}$} & Monitoring & Monitoring & 0.5 & 0.5 & 0.125 & 0.5 \\
\hline & Institutional control & $\begin{array}{l}\text { Institutional } \\
\text { control }\end{array}$ & 0.5 & 0.5 & 0.125 & 0.5 \\
\hline
\end{tabular}

For chemical releases to the atmosphere, Equation (4) has the following units:

Risk $=\left[1 \mathrm{a}\left(\mathrm{kg}_{\text {chemical }}\right)\right]\left[1 \mathrm{~b}\left(\right.\right.$ latent cancer incidence $\left.\left./ \mathrm{mg}_{\text {inhaled }} / \mathrm{kg}_{\text {body }}-\mathrm{d}\right)\right][2 \mathrm{a}][2 \mathrm{~b}]$

$$
\left[3\left(\mathrm{y}^{-1}\right)\right]\left[4 * 5\left(\mathrm{mg}_{\text {inhaled }} / \mathrm{kg}_{\text {chemical }}\right)\right][6(\mathrm{y})][7] \text {. }
$$


Without term (7), this equation has units of latent cancer incidence- $\mathrm{kg}_{\mathrm{body}}-\mathrm{d}$. Therefore, the result must be divided by $70 \mathrm{~kg}_{\text {body }}$. Also, for carcinogenic effects, a 70 -year averaging period is used (when deriving the slope factors), so the result must be divided by $(70 \mathrm{y})(365 \mathrm{~d} / \mathrm{y})=25,550 \mathrm{~d}$. Finally, a conversion from cancer incidence to cancer fatality is needed. ESHRAP uses a conversion factor of one cancer fatality per 3.5 cancer incidences, the same as observed for radiation-induced cancers (DOE 1997a). However, the user can modify this conversion term. Therefore, term (7) for accidental releases (24-hour release) is $\left(1 / 70 \mathrm{~kg}_{\text {body }}\right)(1 / 25,550 \mathrm{~d})(1 / 3.5$ latent cancer fatalities/latent cancer incidences $)=1.6 \mathrm{E}-7$ cancer fatality/cancer incidence- $\mathrm{kg}_{\text {body }}-\mathrm{d}$.

\subsection{Groundwater Pathway Model}

ESHRAP includes waste migration from disposal units through an unsaturated zone (vadose zone) to the groundwater and subsequent exposure to the public (from wells drilled into the groundwater). For other types of activities modeled in ESHRAP, the groundwater pathway is not considered. The pathway model is a modified version of the model outlined in the report Performance Evaluation of the Technical Capabilities of DOE Sites for Disposal of Mixed Low-Level Waste (DOE 1996b). This model was chosen because it had a moderate level of complexity, the results (radionuclide concentration in the groundwater at a given distance from the disposal unit) could be extended to obtain desired ESHRAP results (exposure to the public), and parameters for the model were presented for a number of DOE sites. Steady-state contaminant concentration reduction factors are calculated to obtain a steady-state concentration at the well location(s) (concentration reduction from waste source to leachate entering vadose zone, additional concentration reduction from leachate leaving vadose zone to resulting groundwater concentration, and additional concentration reduction from initial point of entrance into the groundwater to the well location). The concentration of the contaminant in the leachate is based on desorption in the infiltrating water. (This leachate concentration model was based on a grout form for the waste. The results of this model were modified to account for other waste forms.) No dispersion (reduction in contaminant concentration) is modeled for transport through the vadose zone. The concentration reduction when the leachate enters the groundwater is determined by a mixing model (volume of leachate combined with volume of groundwater). Also, the 1996 model did not model dispersion during transport through the groundwater because a very short distance, $100 \mathrm{~m}$, was used. However, for the ESHRAP model, dispersion in the groundwater is modeled. Timing information is also considered (time until waste package is breached, time for transport through the vadose zone, and time for transport through groundwater to well location). Finally, decay of radionuclides is also accounted for.

Changes made to this 1996 groundwater pathway model for incorporation into ESHRAP include the following:

1. Four indicator radionuclides are used in the actinide group (Table 4). Six indicator radionuclides are used in the nonactinide group (Table 4). Chemicals are modeled individually.

2. The contaminant release from the disposal unit to the leachate, originally developed only for grout, was expanded to include other waste forms. The grout results were adjusted up or down to account for different waste forms, based on the parametric studies outlined in the report Smith et al. (1995).

3. Dispersion during transport through the groundwater pathway from the disposal unit location to the well(s) location was added to the model. The dispersion (concentration reduction factor) as a function of distance from the disposal unit location is based on parametric studies of groundwater flow using the computer code GWSCREEN (Rood 1993). The model used was for a homogeneous medium of infinite lateral extent and finite depth with constant, unidirectional flow. The results are as follows 
(Eide et al. 1996):

$\begin{array}{ll}\text { Distance from Source }(m) & \text { Concen } \\ 0-1 E+2 & 1 \\ 1 E+2-3 E+2 & 4 E-1 \\ 3 E+2-5 E+2 & 2 E-1 \\ 5 E+2-1 E+3 & 6 E-2 \\ 1 E+3-2 E+3 & 3 E-2 \\ 2 E+3-1 E+4 & 2 E-3 \\ 1 E+4-2 E+4 & 4 E-4 \\ 2 E+4-5 E+4 & 2 E-4 \\ 5 E+4-1 E+5 & 8 E-5 \\ >1 E+5 & 5 E-5\end{array}$

4. Exposure to the public within $80 \mathrm{~km}(50 \mathrm{mi})$ of the disposal unit is evaluated assuming a fraction (site-specific value) of the people drink well water drawn from the groundwater at the location where the people live. [The present-day population within $80 \mathrm{~km}(50 \mathrm{mi})$ can be assumed constant or can be modeled as linearly increasing to a future constant value.]

5. The duration and timing of actinide, nonactinide, and chemical release from the disposal unit and appearance in the well water (at a distance to the population "center") is calculated such that public exposure can be calculated based on different evaluation periods. For example, if an actinide release duration from the disposal unit is 5,000 years, and the time for that actinide to reach the public well is 7,500 years, then the duration of the public exposure occurs during the period 7,500 to 12,500 years. If the evaluation period is 10,000 years, then only one-half of the total public exposure from that actinide is used. Alternatively, if 1,000 years were chosen as the evaluation period, then none of the total public exposure from the actinide would be used.

The combined model predicts total person-rem (and the timing of this exposure) to the population group under consideration from the indicator actinides and nonactinides. The person-rem results are then converted to latent cancer fatalities. For chemicals, the model predicts latent cancer incidences (and the timing of this exposure). These are then converted to latent cancer fatalities.

The exposure risk (latent cancer fatalities to population group being considered) is calculated separately for actinides, nonactinides, and each chemical. For each indicator actinide, the exposure risk is the following:

$$
\begin{array}{ll}
\text { Risk }_{\text {act. }}= & \left(1 \mathrm{a}_{\text {act. }} / \mathrm{V}_{\text {disposal unit }}\right)\left(1 \mathrm{a}_{\text {decay, act. }}\right)\left(1 \mathrm{~b}_{\text {ingestion, act. }}\right)\left(\mathrm{CRF}_{\text {source, act. }}\right)^{-1}\left(\mathrm{CRF}_{\text {water }}\right)^{-1} \\
& \left(4 * 5 \mathrm{p}_{\text {water }}\right)(\mathrm{FI})(\mathrm{IR})\left(\mathrm{ED}_{\text {act. }}\right)\left(\mathrm{Z}_{\text {act. }}\right)(\mathrm{C})
\end{array}
$$

$$
\begin{array}{lll}
\text { where Risk } \text { act. } & = & \begin{array}{l}
\text { Risk to population within } 80 \mathrm{~km}(50 \mathrm{mi}) \text { that drink contaminated } \\
\text { groundwater, from indicator actinide (fatalities) }
\end{array} \\
1 \mathrm{a}_{\text {act. }} & = & \begin{array}{l}
\text { initial Ci total for indicator actinide } \\
\text { volume of disposal unit }
\end{array} \\
\mathrm{V}_{\text {disposal unit }} & = & \mathrm{V}_{\text {waste }} / \mathrm{f}_{\mathrm{m}}\left(\mathrm{m}^{3}\right) \\
\mathrm{f}_{\mathrm{m}} & = & \text { fraction of disposal unit volume occupied by waste volume } \\
1 \mathrm{a}_{\text {decay, act. }} & = & \text { decay fraction for indicator actinide Ci total } \\
& = & \exp \left\{-[\ln (2)]\left(\Delta \mathrm{T}_{\text {decay, act. }}\right) / \mathrm{T}_{1 / 2, \text { act. }}\right\} \\
\mathrm{T}_{1 / 2, \text { act. }} & = & \text { half-life of indicator actinide } \\
\Delta \mathrm{T}_{\text {decay, act. }} & = & \Delta \mathrm{T}_{\text {barrier }}+\Delta \mathrm{T}_{\mathrm{vz}, \text { act. }}+\Delta \mathrm{T}_{\mathrm{gw}, \text { act. }}+(0.5)\left(\Delta \mathrm{T}_{\mathrm{rd}, \text { act. }}\right)(\mathrm{y})
\end{array}
$$




\begin{tabular}{|c|c|c|}
\hline \multirow{3}{*}{$\begin{array}{l}\Delta \mathrm{T}_{\text {barrier }} \\
\Delta \mathrm{T}_{\mathrm{vz} \text {, act. }}\end{array}$} & $=$ & waste barrier lifetime $(\mathrm{y})$ \\
\hline & $=$ & retarded travel time for indicator actinide through vadose zone \\
\hline & $=$ & {$\left[1_{\mathrm{vz}} \theta_{\mathrm{vz}} / \mathrm{q}_{\mathrm{vz}}\right]\left[1+\mathrm{K}_{\mathrm{d}, \mathrm{vz}, \text { act. }} \rho_{\mathrm{b}, \mathrm{vz}} / \theta_{\mathrm{vz}}\right](\mathrm{y})$} \\
\hline $1_{\mathrm{vz}}$ & $=$ & depth from disposal unit to groundwater (m) \\
\hline$\theta_{\mathrm{vz}}$ & $=$ & volumetric moisture content of vadose zone $\left(\mathrm{mL} / \mathrm{cm}^{3}\right)$ \\
\hline $\mathrm{q}_{\mathrm{vz}}$ & $=$ & natural recharge (velocity of water through vadose zone) (m/y) \\
\hline $\mathrm{K}_{\mathrm{d}, \mathrm{vz} \text {, act. }}$ & $=$ & distribution coefficient for indicator actinide in vadose zone $(\mathrm{mL} / \mathrm{g})$ \\
\hline$\rho_{\mathrm{b}, \mathrm{vz}}$ & $=$ & dry bulk density of geologic media in vadose zone $\left(\mathrm{g} / \mathrm{cm}^{3}\right)$ \\
\hline \multirow[t]{2}{*}{$\Delta \mathrm{T}_{\mathrm{gw}, \text { act. }}$} & $=$ & $\begin{array}{l}\text { retarded travel time for indicator actinide through groundwater to } \\
\text { population "center" }\end{array}$ \\
\hline & $=$ & {$\left[\mathrm{D}_{\mathrm{pop}} \mathrm{n}_{\mathrm{gw}} / \mathrm{q}_{\mathrm{gw}}\right]\left[1+\mathrm{K}_{\mathrm{d}, \mathrm{gw}, \mathrm{act} .} \rho_{\mathrm{b}, \mathrm{gw}} / \mathrm{n}_{\mathrm{gw}}\right](\mathrm{y})$} \\
\hline $\mathrm{D}_{\text {pop }}$ & $=$ & distance to population "center" (m) \\
\hline $\mathrm{n}_{\mathrm{gw}}$ & $=$ & porosity of geologic media in groundwater zone \\
\hline $\mathrm{q}_{\mathrm{gw}}$ & $=$ & groundwater Darcy velocity $(\mathrm{m} / \mathrm{s})$ \\
\hline $\mathrm{K}_{\mathrm{d} \text {, gw,act. }}$ & $=$ & distribution coefficient for indicator actinide in groundwater $(\mathrm{mL} / \mathrm{g})$ \\
\hline$\rho_{\mathrm{b}, \mathrm{gw}}$ & $=$ & dry bulk density of geologic media in groundwater zone $\left(\mathrm{g} / \mathrm{cm}^{3}\right)$ \\
\hline \multirow[t]{2}{*}{$\Delta \mathrm{T}_{\text {rd, act. }}$} & $=$ & release duration for indicator actinide \\
\hline & $=$ & $\left(\mathrm{d}_{\mathrm{th}} \mathrm{CRF}_{\text {source, act. }}\right) / \mathrm{q}_{\mathrm{vz}}(\mathrm{y})$ \\
\hline $\mathrm{d}_{\mathrm{th}}$ & $=$ & thickness of disposal unit (m) \\
\hline \multirow[t]{2}{*}{$\mathrm{CRF}_{\text {source, act. }}$} & $=$ & $\begin{array}{l}\text { concentration reduction factor, ratio of indicator actinide } \mathrm{Ci} \\
\text { concentration in disposal unit to concentration in leachate leaving the } \\
\text { disposal unit }\end{array}$ \\
\hline & $=$ & $\left(\theta_{\mathrm{wf}}+\mathrm{K}_{\mathrm{d}, \mathrm{wf}, \text { act. }} \rho_{\mathrm{wf}}\right) / \mathrm{f}_{\mathrm{m}}$ \\
\hline$\theta_{\mathrm{wf}}$ & $=$ & volumetric moisture content of waste form $\left(\mathrm{mL} / \mathrm{cm}^{3}\right)$ \\
\hline $\mathrm{K}_{\mathrm{d} \text {, wf, act. }}$ & $=$ & distribution coefficient for indicator actinide in waste form $(\mathrm{mL} / \mathrm{g})$ \\
\hline$\rho_{\mathrm{wf}}$ & $=$ & dry bulk density of waste form $\left(\mathrm{g} / \mathrm{cm}^{3}\right)$ \\
\hline $1 b_{\text {ingestion, act. }}$ & $=$ & dose conversion factor for actinide $(\mathrm{rem} / \mu \mathrm{Ci})$ \\
\hline \multirow[t]{2}{*}{$\mathrm{CRF}_{\text {water }}$} & $=$ & $\begin{array}{l}\text { concentration reduction factor, ratio of concentration in leachate leaving } \\
\text { disposal unit to concentration in groundwater }\end{array}$ \\
\hline & $=$ & $\left(q_{v z} a_{1}+q_{g w} d_{m}\right) /\left(q_{v z} a_{1}\right)$ \\
\hline$a_{1}$ & $=$ & length of disposal unit in direction of groundwater flow (m) \\
\hline$d_{m}$ & $=$ & mixing depth in groundwater $(\mathrm{m})$ \\
\hline $4 * 5 p_{\text {water }}$ & $=$ & $\begin{array}{l}\Sigma(\text { population at distance } \mathrm{x} \text { from disposal unit)(groundwater } \\
\text { concentration reduction factor at distance } \mathrm{x}) \text {, evaluated from } 0 \text { to } \\
80,000 \mathrm{~m}(50 \mathrm{mi}) \text { (person) }\end{array}$ \\
\hline FI & $=$ & fraction of population using groundwater as drinking water \\
\hline IR & $=$ & ingestion rate of well water per person per day $\left(\mathrm{m}^{3} / \mathrm{y}\right)$ \\
\hline \multirow[t]{4}{*}{$\mathrm{ED}_{\text {act. }}$} & $=$ & exposure duration \\
\hline & $=$ & evaluation period (user input) $-\Delta \mathrm{T}_{\text {barrier }}-\Delta \mathrm{T}_{\mathrm{vz}}-\Delta \mathrm{T}_{\mathrm{gw}}(\mathrm{y})$ \\
\hline & & If $\mathrm{ED}_{\text {act. }}>\Delta \mathrm{T}_{\text {rd, act. }}$, then $\mathrm{ED}_{\text {act. }}=\Delta \mathrm{T}_{\text {rd, act. }}$ \\
\hline & & If $\mathrm{ED}_{\text {act. }}<0$, then $\mathrm{ED}_{\text {act. }}=0$ \\
\hline$Z_{\text {act. }}$ & $=$ & fraction of actinide $\mathrm{Ci}$ total that is from the indicator radionuclide \\
\hline $\mathrm{C}$ & $=$ & $\begin{array}{l}\text { units conversion factor }=(1 \mathrm{E}+6 \mu \mathrm{Ci} / \mathrm{Ci})(5 \mathrm{E}-4 \text { latent cancer } \\
\text { fatality/person-rem })=5 \mathrm{E}+2\end{array}$ \\
\hline
\end{tabular}

To allow for sensitivity studies and better fits to more detailed modeling results, a multiplier on $\Delta \mathrm{T}_{\text {rd, act. }}$ is provided. This multiplier $(\geq 1.0)$ extends the release duration. This multiplier is also applied to $\mathrm{CRF}_{\text {source,act. }}$ in order to preserve the total release quantity. 
For nonactinide exposure risk, the equation is the same as for actinides, except that the indicator actinide is replaced by the indicator nonactinide.

For chemical exposure risk, the risk equation for each chemical is the following:

\begin{tabular}{|c|c|c|}
\hline Risk $_{\text {chem }}$ & $=$ & $\begin{array}{l}\left(1 \mathrm{a}_{\text {chem }} / \mathrm{V}_{\text {disposal unit }}\right)\left(1 \mathrm{a}_{\text {decay, chem. }}\right)\left(1 \mathrm{~b}_{\text {ingestion, chem. }}\right)\left(\mathrm{CRF}_{\text {source, chem. }}\right)^{-1}\left(\mathrm{CRF}_{\text {water }}\right)^{-1} \\
\left(4 * 5 \mathrm{p}_{\text {water }}\right)(\mathrm{FI})(\mathrm{IR})\left(\mathrm{ED}_{\text {chem. }}\right)\left(\mathrm{Z}_{\text {chem }}\right)(\mathrm{C})\end{array}$ \\
\hline where Risk ${ }_{\text {chem }}$ & $=$ & $\begin{array}{l}\text { Risk to population within } 80 \mathrm{~km}(50 \mathrm{mi}) \text { that drink contaminated } \\
\text { groundwater, from chemical (fatalities) }\end{array}$ \\
\hline $1 \mathrm{a}_{\text {chem }}$ & $=$ & initial $\mathrm{kg}$ total for chemical being considered \\
\hline $\mathrm{V}_{\text {disposal unit }}$ & $=$ & volume of disposal unit \\
\hline & $=$ & $\mathrm{V}_{\text {waste }} / \mathrm{f}_{\mathrm{m}}\left(\mathrm{m}^{3}\right)$ \\
\hline $\mathrm{f}_{\mathrm{m}}$ & $=$ & fraction of disposal unit volume occupied by waste volume \\
\hline $1 \mathrm{a}_{\text {decay, chem }}$ & $=$ & decay fraction for chemical $\mathrm{kg}$ total \\
\hline & $=$ & $\exp \left\{-[\ln (2)]\left(\Delta \mathrm{T}_{\text {decay, chem }}\right) / \mathrm{T}_{1 / 2, \text { chem }}\right\}$ \\
\hline $\mathrm{T}_{1 / 2, \text { chem }}$ & $=$ & half-life of chemical \\
\hline$\Delta \mathrm{T}_{\text {decay, chem }}$ & $=$ & $\Delta \mathrm{T}_{\text {barrier }}+\Delta \mathrm{T}_{\mathrm{vz}, \text { chem }}+\Delta \mathrm{T}_{\mathrm{gw}, \text { chem }}+(0.5)\left(\Delta \mathrm{T}_{\mathrm{rd}, \text { chem }}\right)(\mathrm{y})$ \\
\hline$\Delta \mathrm{T}_{\text {barrier }}$ & $=$ & waste barrier lifetime (y) \\
\hline$\Delta \mathrm{T}_{\mathrm{vz}, \mathrm{chem}}$ & $=$ & retarded travel time for chemical through vadose zone \\
\hline & $=$ & {$\left[1_{\mathrm{vz}} \theta_{\mathrm{vz}} / \mathrm{q}_{\mathrm{vz}}\right]\left[1+\mathrm{K}_{\mathrm{d}, \mathrm{vz}, \mathrm{chem}} \rho_{\mathrm{b}, \mathrm{vz}} / \theta_{\mathrm{vz}}\right](\mathrm{y})$} \\
\hline $1_{\mathrm{vz}}$ & $=$ & depth from disposal unit to groundwater (m) \\
\hline$\theta_{\mathrm{vz}}$ & $=$ & volumetric moisture content of vadose zone $\left(\mathrm{mL} / \mathrm{cm}^{3}\right)$ \\
\hline $\mathrm{q}_{\mathrm{vz}}$ & $=$ & natural recharge (velocity of water through vadose zone) $(\mathrm{m} / \mathrm{y})$ \\
\hline $\mathrm{K}_{\mathrm{d}, \mathrm{vz}, \mathrm{chem}}$ & $=$ & distribution coefficient for chemical in vadose zone $(\mathrm{mL} / \mathrm{g})$ \\
\hline$\rho_{\mathrm{b}, \mathrm{vz}}$ & $=$ & dry bulk density of geologic media in vadose zone $\left(\mathrm{g} / \mathrm{cm}^{3}\right)$ \\
\hline$\Delta \mathrm{T}_{\mathrm{gw}, \text { chem }}$ & $=$ & $\begin{array}{l}\text { retarded travel time for chemical through groundwater to } \\
\text { population "center" }\end{array}$ \\
\hline & $=$ & {$\left[\mathrm{D}_{\mathrm{pop}} \mathrm{n}_{\mathrm{gw}} / \mathrm{q}_{\mathrm{gw}}\right]\left[1+\mathrm{K}_{\mathrm{d}, \mathrm{gw}, \mathrm{chem}} \rho_{\mathrm{b}, \mathrm{gw}} / \mathrm{n}_{\mathrm{gw}}\right](\mathrm{y})$} \\
\hline $\mathrm{D}_{\text {pop }}$ & $=$ & distance to population "center" $(\mathrm{m})$ \\
\hline $\mathrm{n}_{\mathrm{gw}}$ & $=$ & porosity of geologic media in groundwater zone \\
\hline $\mathrm{q}_{\mathrm{gw}}$ & $=$ & groundwater Darcy velocity $(\mathrm{m} / \mathrm{s})$ \\
\hline $\mathrm{K}_{\mathrm{d} \text {, gw,chem }}$ & $=$ & distribution coefficient for chemical in groundwater $(\mathrm{mL} / \mathrm{g})$ \\
\hline$\rho_{\mathrm{b}, \mathrm{gw}}$ & $=$ & dry bulk density of geologic media in groundwater zone $\left(\mathrm{g} / \mathrm{cm}^{3}\right)$ \\
\hline$\Delta \mathrm{T}_{\mathrm{rd}, \text { chem }}$ & $=$ & release duration for chemical \\
\hline & $=$ & $\left(\mathrm{d}_{\mathrm{th}} \mathrm{CRF}_{\text {source, chem }}\right) / \mathrm{q}_{\mathrm{vz}}(\mathrm{y})$ \\
\hline $\mathrm{d}_{\mathrm{th}}$ & $=$ & thickness of disposal unit (m) \\
\hline $\mathrm{CRF}_{\text {source, chem }}$ & $=$ & $\begin{array}{l}\text { concentration reduction factor, ratio of chemical concentration in } \\
\text { disposal unit to concentration in leachate leaving the disposal unit }\end{array}$ \\
\hline & $=$ & $\left(\theta_{\mathrm{wf}}+\mathrm{K}_{\mathrm{d}, \mathrm{wf}, \mathrm{chem}} \rho_{\mathrm{wf}}\right) / \mathrm{f}_{\mathrm{m}}$ \\
\hline$\theta_{\mathrm{wf}}$ & $=$ & volumetric moisture content of waste form $\left(\mathrm{mL} / \mathrm{cm}^{3}\right)$ \\
\hline $\mathrm{K}_{\mathrm{d}, \mathrm{wf} \text {, chem }}$ & $=$ & distribution coefficient for chemical in waste form $(\mathrm{mL} / \mathrm{g})$ \\
\hline$\rho_{\mathrm{wf}}$ & $=$ & dry bulk density of waste form $\left(\mathrm{g} / \mathrm{cm}^{3}\right)$ \\
\hline $1 b_{\text {ingestion, chem }}$ & $=$ & effective slope factor for chemical ingestion (kg-d/mg) \\
\hline $\mathrm{CRF}_{\text {water }}$ & $=$ & $\begin{array}{l}\text { concentration reduction factor, ratio of concentration in leachate leaving } \\
\text { disposal unit to concentration in groundwater }\end{array}$ \\
\hline & $=$ & $\left(q_{v z} a_{1}+q_{g w} d_{m}\right) /\left(q_{v z} a_{1}\right)$ \\
\hline$a_{1}$ & $=$ & length of disposal unit in direction of groundwater flow (m) \\
\hline $\mathrm{d}_{\mathrm{m}}$ & $=$ & mixing depth in groundwater $(\mathrm{m})$ \\
\hline $4 * 5 p_{\text {water }}$ & $=$ & $\Sigma$ (population at distance $\mathrm{x}$ from disposal unit)(groundwater \\
\hline
\end{tabular}




\begin{tabular}{|c|c|c|}
\hline & & $\begin{array}{l}\text { concentration reduction factor at distance } \mathrm{x}) \text {, evaluated from } 0 \text { to } \\
80,000 \mathrm{~m}(50 \mathrm{mi}) \text { (person) }\end{array}$ \\
\hline FI & $=$ & fraction of population using groundwater as drinking water \\
\hline IR & $=$ & ingestion rate of well water per person per day $\left(\mathrm{m}^{3} / \mathrm{y}\right)$ \\
\hline $\mathrm{ED}_{\text {chem }}$ & $=$ & exposure duration \\
\hline & $=$ & evaluation period (user input) $-\Delta \mathrm{T}_{\text {barrier }}-\Delta \mathrm{T}_{\mathrm{vz}}-\Delta \mathrm{T}_{\mathrm{gw}}(\mathrm{y})$ \\
\hline & & $\begin{array}{l}\text { If } \mathrm{ED}_{\text {chem }}>\Delta \mathrm{T}_{\text {rd, chem, }} \text {, then } \mathrm{ED}_{\text {chem }}=\Delta \mathrm{T}_{\text {rd, chem }} \\
\text { If } \mathrm{ED}_{\text {chem }}<0 \text {, then } \mathrm{ED}_{\text {chem }}=0\end{array}$ \\
\hline$Z_{\text {chem }}$ & $=$ & 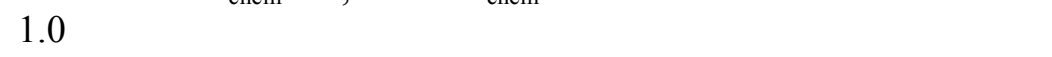 \\
\hline $\mathrm{C}$ & $=$ & $\begin{array}{l}\text { units conversion factor }=(1 \mathrm{E}+6 \mathrm{mg} / \mathrm{kg})(1 \text { cancer fatality } / 3.5 \text { cancer } \\
\text { incidences })=2.9 \mathrm{E}+5\end{array}$ \\
\hline
\end{tabular}

The groundwater pathway model requires a significant amount of site-specific parameter values. Site-specific parameters (except for radionuclide- and chemical-specific distribution coefficients) are presented in Table 14. Vadose zone distribution coefficients for the ten indicator radionuclides are presented in Table 15, and groundwater distribution coefficients are presented in Table 16. Finally, waste form release $\left(\mathrm{CRF}_{\text {source}}\right)$ values for radionuclides are presented in Table 17.

Table 14. Site-specific groundwater pathway model parameters except for distribution coefficients.

\begin{tabular}{|c|c|c|c|c|c|c|c|c|c|c|c|}
\hline Site & $\begin{array}{l}4 * 5 p_{\text {water }} \\
\text { (person) }\end{array}$ & FI & $\begin{array}{l}\mathrm{L}_{\mathrm{vz}} \\
(\mathrm{m})\end{array}$ & $\theta_{\mathrm{vz}}$ & $\begin{array}{c}\mathrm{q}_{\mathrm{vz}} \\
(\mathrm{m} / \mathrm{y})\end{array}$ & $\begin{array}{r}\rho_{\mathrm{b}, \mathrm{vz}} \\
\left(\mathrm{g} / \mathrm{cm}^{3}\right)\end{array}$ & $\mathrm{n}_{\mathrm{gw}}$ & $\begin{array}{c}\mathrm{q}_{\mathrm{gw}} \\
(\mathrm{m} / \mathrm{y})\end{array}$ & $\begin{array}{r}\mathrm{d}_{\mathrm{m}} \\
(\mathrm{m}) \\
\end{array}$ & $\begin{array}{c}\rho_{\mathrm{b}, \mathrm{gw}} \\
\left(\mathrm{g} / \mathrm{cm}^{3}\right)\end{array}$ & $\begin{array}{l}\begin{array}{l}\mathrm{D}_{\text {pop }} \\
(\mathrm{m})\end{array} \\
\end{array}$ \\
\hline ANL-E & 1100 & 0.5 & 38 & 0.16 & 0.102 & 1.9 & 0.03 & 6 & 3 & 2.7 & $2.4 \mathrm{E}+4$ \\
\hline BNL & 750 & 0.5 & & & & & & & & & \\
\hline Envirocare & 0 & 0.0 & & & & & & & & & \\
\hline ETEC & 1160 & 0.5 & & & & & & & & & \\
\hline FEMP & 380 & 0.5 & 6.7 & 0.04 & 0.15 & 1.6 & 0.3 & 28 & 3 & 1.6 & $4.0 \mathrm{E}+4$ \\
\hline Hanford & 40 & 0.5 & 72 & 0.09 & 0.05 & 1.5 & 0.31 & 22 & 5 & 1.6 & $5.6 \mathrm{E}+4$ \\
\hline INEEL & 15 & 0.1 & 50 & 0.17 & 0.07 & 1.5 & 0.1 & 56 & 12 & 1.9 & $6.4 \mathrm{E}+4$ \\
\hline KAPL-K & 1100 & 0.5 & & & & & & & & & \\
\hline KCP & 840 & 0.5 & & & & & & & & & \\
\hline $\mathrm{K}-25$ & 110 & 0.5 & & & & & & & & & \\
\hline LANL & 30 & 0.5 & 333 & 0.05 & 0.02 & 1.22 & 0.30 & 23 & 9 & 1.86 & $2.4 \mathrm{E}+4$ \\
\hline LBL & 2980 & 0.5 & & & & & & & & & \\
\hline LLNL & 820 & 0.5 & 162 & 0.17 & 0.025 & 2.0 & 0.25 & 9.9 & 11 & 2.0 & $5.6 \mathrm{E}+4$ \\
\hline Mound & 740 & 0.5 & & & & & & & & & \\
\hline MSP & 2480 & 0.5 & & & & & & & & & \\
\hline NTS & 1.4 & 0.5 & 195 & 0.1 & 0.003 & 2.3 & 0.25 & 2.3 & 10 & 2.0 & $6.4 \mathrm{E}+4$ \\
\hline ORNL & 110 & 0.5 & 2 & 0.305 & 0.18 & 1.35 & 0.035 & 2.92 & 3 & 1.35 & $4.0 \mathrm{E}+4$ \\
\hline Pantex & 30 & 0.5 & 122 & 0.1 & 0.006 & 1.9 & 0.25 & 6 & 11 & 1.9 & $3.2 \mathrm{E}+4$ \\
\hline PGDP & 70 & 0.5 & 15.5 & 0.2 & 0.12 & 1.7 & 0.25 & 25 & 9 & 2.0 & $4.0 \mathrm{E}+4$ \\
\hline Pinellas & 1080 & 0.5 & & & & & & & & & \\
\hline Portsmouth & 80 & 0.5 & 5 & 0.22 & 0.11 & 1.7 & 0.35 & 7.7 & 2.5 & 1.5 & $4.0 \mathrm{E}+4$ \\
\hline RFETS & 320 & 0.5 & 12.8 & 0.12 & 0.05 & 1.34 & 0.1 & 0.59 & 11.6 & 1.34 & $2.4 \mathrm{E}+4$ \\
\hline SNL-NM & 970 & 0.5 & 150 & 0.07 & 0.02 & 1.8 & 0.3 & 0.5 & 15 & 1.8 & $1.6 \mathrm{E}+3$ \\
\hline SRS & 60 & 0.5 & 17 & 0.2 & 0.4 & 2.65 & 0.3 & 8.1 & 10 & 2.65 & $5.6 \mathrm{E}+4$ \\
\hline WIPP & 10 & 0.0 & & & & & & & & & \\
\hline WVDP & 180 & 0.5 & 13 & 0.3 & 0.07 & 1.6 & 0.36 & 0.31 & 6 & 2 & $5.6 \mathrm{E}+4$ \\
\hline Y-12 & 190 & 0.5 & & & & & & & & & \\
\hline Yucca Mt. & 1.4 & 0.5 & 300 & 0.005 & 0.008 & 2.3 & 0.25 & 2.3 & 10 & 2.0 & $6.4 \mathrm{E}+4$ \\
\hline
\end{tabular}

Sources: Most parameter values were obtained from Performance Evaluation of the Technical Capabilities of DOE Sites for Disposal of Mixed Low-Level Waste (DOE 1996b). 4*5 $\mathrm{b}_{\text {water }}$ was estimated using site-specific population distribution information from the DOE (1997a) and groundwater dispersion (concentration reduction factors) obtained from Eide et al. (1996). FI, the fraction of the population using groundwater for drinking water for each site, is mainly a placeholder at this time. The INEEL value is a rough estimate based on local groundwater usage. $\mathrm{D}_{\text {pop }}$ was estimated from population data in DOE (1997a). Values highlighted in gray were obtained from various site-specific sources or were estimated. 
Table 15. Site-specific vadose zone distribution coefficients for indicator radionuclides.

\begin{tabular}{|c|c|c|c|c|c|c|c|c|c|c|}
\hline & \multicolumn{10}{|c|}{ Vadose Zone Distribution Coefficient $(\mathrm{mL} / \mathrm{g})$} \\
\hline & \multicolumn{6}{|c|}{ Nonactinide Indicator Radionuclide } & \multicolumn{4}{|c|}{ Actinide Indicator Radionuclide } \\
\hline Site & $\mathrm{C}-14$ & Sr-90 & Tc-99 & $\mathrm{I}-129$ & Cs-137 & Ra-226 & U-234 & Np-237 & $\mathrm{U}-238$ & $\mathrm{Pu}-239$ \\
\hline ANL-E & 5. & 15. & 0.1 & 1. & 280. & 500. & 35. & 5. & 35. & 550. \\
\hline \multicolumn{11}{|l|}{ BNL } \\
\hline \multicolumn{11}{|l|}{ Envirocare } \\
\hline \multicolumn{11}{|l|}{ ETEC } \\
\hline FEMP & 5. & 20. & 0.02 & 1. & 280. & 700. & 3.1 & 2.4 & 3.1 & 550. \\
\hline Hanford & 0 . & 1. & 0 . & 0 . & 1. & 10. & 0 . & 10. & 0 . & 100. \\
\hline INEEL & 0 . & 2. & 0.15 & 0.05 & 20. & 50. & 1000. & 50. & 1000. & 2000. \\
\hline \multicolumn{11}{|l|}{ KAPL-K } \\
\hline \multicolumn{11}{|l|}{ KCP } \\
\hline \multicolumn{11}{|l|}{ K-25 } \\
\hline LANL & 0 . & 116. & 0.3 & 0 . & 428. & 200. & 1.8 & 0.007 & 1.8 & 110. \\
\hline \multicolumn{11}{|l|}{$\overline{\mathrm{LBL}}$} \\
\hline$\overline{\text { LLNL }}$ & 5. & 15. & 0.1 & 1. & 280. & 500. & 35. & 5. & 35. & 550. \\
\hline \multicolumn{11}{|l|}{ Mound } \\
\hline \multicolumn{11}{|l|}{ MSP } \\
\hline \multicolumn{11}{|l|}{ NTS } \\
\hline ORNL & 0 . & 30. & 0. & 1. & 3000 . & 3000 . & 40. & 40. & 40. & 40. \\
\hline Pantex & 5. & 15. & 0.1 & 1. & 280. & 500. & 35. & 5. & 35. & 550. \\
\hline PGDP & 5. & 15. & 0.1 & 1. & 280. & 500. & 35. & 5. & 35. & 550. \\
\hline \multicolumn{11}{|l|}{ Pinellas } \\
\hline Portsmouth & 5. & 15. & 0.1 & 1. & 280. & 500. & 35. & 5. & 35. & 550. \\
\hline RFETS & 5. & 15. & 0.1 & 1. & 280. & 500. & 35. & 5. & 35. & 550. \\
\hline SNL-NM & 5. & 15. & 0.1 & 1. & 280. & 500. & 35. & 5. & 35. & 550. \\
\hline SRS & 2. & 10. & 0.4 & 0.6 & 100. & 500. & 50. & 10. & 50. & 100. \\
\hline \multicolumn{11}{|l|}{ WIPP } \\
\hline WVDP & 1. & 5 . & 2. & 1. & 40. & & 22. & 1900. & 22. & 1150. \\
\hline \multicolumn{11}{|l|}{ Y-12 } \\
\hline Yucca Mt. & & & 0.1 & & & & & 1. & & \\
\hline
\end{tabular}

Sources: Most parameter values were obtained from Performance Evaluation of the Technical Capabilities of DOE Sites for Disposal of Mixed Low-Level Waste (DOE 1996b).

Similar information for chemicals is presented in Tables 18 through 23. Tables 18 and 19 present the site- and chemical-specific vadose zone distribution coefficients, while Tables 20 and 21 contain similar information for groundwater. Finally, Tables 22 and 23 present the material form release parameters. 
Table 16. Site-specific groundwater distribution coefficients for indicator radionuclides.

\begin{tabular}{|c|c|c|c|c|c|c|c|c|c|c|}
\hline & \multicolumn{10}{|c|}{ Groundwater Distribution Coefficient $(\mathrm{mL} / \mathrm{g})$} \\
\hline & \multicolumn{6}{|c|}{ Nonactinide Indicator Radionuclide } & \multicolumn{4}{|c|}{ Actinide Indicator Radionuclide } \\
\hline Site & $\mathrm{C}-14$ & Sr-90 & Tc-99 & I-129 & Cs-137 & Ra-226 & U-234 & Np-237 & U-238 & Pu-239 \\
\hline ANL-E & 5. & 15. & 0.1 & 1. & 280. & 500. & 7. & 20. & 7. & 500. \\
\hline \multicolumn{11}{|l|}{ BNL } \\
\hline \multicolumn{11}{|l|}{ Envirocare } \\
\hline \multicolumn{11}{|l|}{ ETEC } \\
\hline FEMP & 5 . & 15. & 0.02 & 1. & 280 & 500. & 1.8 & 2.4 & 1.8 & 550. \\
\hline Hanford & 0. & 1. & 0. & 0 . & 1. & 10. & 0. & 10. & 0 . & 100. \\
\hline INEEL & 0. & 2. & 0.15 & 0.05 & 20. & 5. & 100. & 5. & 100. & 200. \\
\hline \multicolumn{11}{|l|}{ KAPL-K } \\
\hline \multicolumn{11}{|l|}{$\mathrm{KCP}$} \\
\hline \multicolumn{11}{|l|}{$\mathrm{K}-25$} \\
\hline LANL & 5 . & 15. & 0.1 & 1. & 280. & 500. & 35. & 5. & 35. & 550. \\
\hline \multicolumn{11}{|l|}{ LBL } \\
\hline LLNL & 5. & 15. & 0.1 & 1. & 280. & 500. & 35. & 5. & 35. & 550. \\
\hline \multicolumn{11}{|l|}{ Mound } \\
\hline \multicolumn{11}{|l|}{ MSP } \\
\hline \multicolumn{11}{|l|}{ NTS } \\
\hline ORNL & 0. & 30. & 0. & 1. & 3000. & 3000 . & 40. & 40. & 40. & 40. \\
\hline Pantex & 5. & 15. & 0.1 & 1. & 280. & 500. & 35. & 5. & 35. & 550. \\
\hline PGDP & 5. & 15. & 0.1 & 1. & 280. & 500. & 35. & 5. & 35. & 550. \\
\hline \multicolumn{11}{|l|}{ Pinellas } \\
\hline Portsmouth & 5. & 15. & 0.1 & 1. & 280. & 500. & 35. & 5. & 35. & 550. \\
\hline RFETS & 5. & 15. & 0.1 & 1. & 280. & 500. & 35. & 5. & 35. & 550. \\
\hline SNL-NM & 5. & 15. & 0.1 & 1. & 280. & 500. & 35. & 5. & 35. & 550. \\
\hline SRS & 2. & 10. & 0.4 & 0.6 & 100. & 500. & 50. & 10. & 50. & 100. \\
\hline \multicolumn{11}{|l|}{ WIPP } \\
\hline WVDP & 1. & 5. & 2. & 1. & 40. & & 22. & & 22. & 1150. \\
\hline \multicolumn{11}{|l|}{ Y-12 } \\
\hline Yucca Mt. & & & 0.1 & & & & & 10. & & \\
\hline
\end{tabular}

Sources: Most parameter values were obtained from Performance Evaluation of the Technical Capabilities of DOE Sites for Disposal of Mixed Low-Level Waste (DOE 1996b).

Table 17. Material form release to leachate parameters for indicator radionuclides.

\begin{tabular}{|c|c|c|c|}
\hline Material Form & & $\left(\mathrm{f}_{\mathrm{m}} * \mathrm{CRF}_{\text {source }}\right)^{-}$ & \\
\hline & $\begin{array}{c}\text { Tc-99 } \\
\mathrm{I}-129 \\
\\
\left(\mathrm{~K}_{\mathrm{d}, \text { grout }}=1.0\right) \\
\end{array}$ & $\begin{array}{c}\mathrm{C}-14 \\
\text { Cs-137 } \\
\text { Ra-226 } \\
\\
\left(\mathrm{K}_{\mathrm{d}, \text { grout }}=10\right) \\
\end{array}$ & $\begin{array}{c}\text { Sr-90 } \\
\text { U-234 } \\
\text { Np-237 } \\
\text { U-238 } \\
\text { Pu-239 } \\
\left(\mathrm{K}_{\mathrm{d}, \text { grout }}=100\right) \\
\end{array}$ \\
\hline Gas or vapor from highly volatile liquid & $1.0 \mathrm{E}-6$ & $1.0 \mathrm{E}-6$ & $1.0 \mathrm{E}-6$ \\
\hline Organic solvent & 1.0 & 1.0 & $5.7 \mathrm{E}-1$ \\
\hline Low volatility liquid & 1.0 & 1.0 & $5.7 \mathrm{E}-1$ \\
\hline Loose contamination on surface of solids & 1.0 & $5.6 \mathrm{E}-1$ & $5.7 \mathrm{E}-2$ \\
\hline Powder & 1.0 & $4.5 \mathrm{E}-1$ & $4.6 \mathrm{E}-2$ \\
\hline Calcine (granular solid) & 1.0 & $3.4 \mathrm{E}-1$ & $3.4 \mathrm{E}-2$ \\
\hline Sludge & 1.0 & $1.7 \mathrm{E}-1$ & $1.7 \mathrm{E}-2$ \\
\hline Cement, concrete, or grout & $4.8 \mathrm{E}-1$ & $5.6 \mathrm{E}-2$ & $5.7 \mathrm{E}-3$ \\
\hline Glass or ceramic & $4.8 \mathrm{E}-2$ & $5.6 \mathrm{E}-3$ & $5.7 \mathrm{E}-4$ \\
\hline Metal (non-pyrophoric) & $9.6 \mathrm{E}-3$ & $1.1 \mathrm{E}-3$ & $1.1 \mathrm{E}-4$ \\
\hline
\end{tabular}

Sources: The grout values were obtained using information from Performance Evaluation of the Technical

Capabilities of DOE Sites for Disposal of Mixed Low-Level Waste (DOE 1996b). In that report, $\theta_{\mathrm{g}}=0.3$, and $\rho_{\mathrm{g}}=$ $1.76 \mathrm{~g} / \mathrm{cm}^{3}$. Other waste form values were estimated based on recommended values listed in Eide et al. (1996), which were obtained primarily from Preliminary Parametric Performance Assessment of Potential Final Waste Forms for Alpha Low-level Waste at the Idaho National Engineering Laboratory (Smith et al. 1995). 


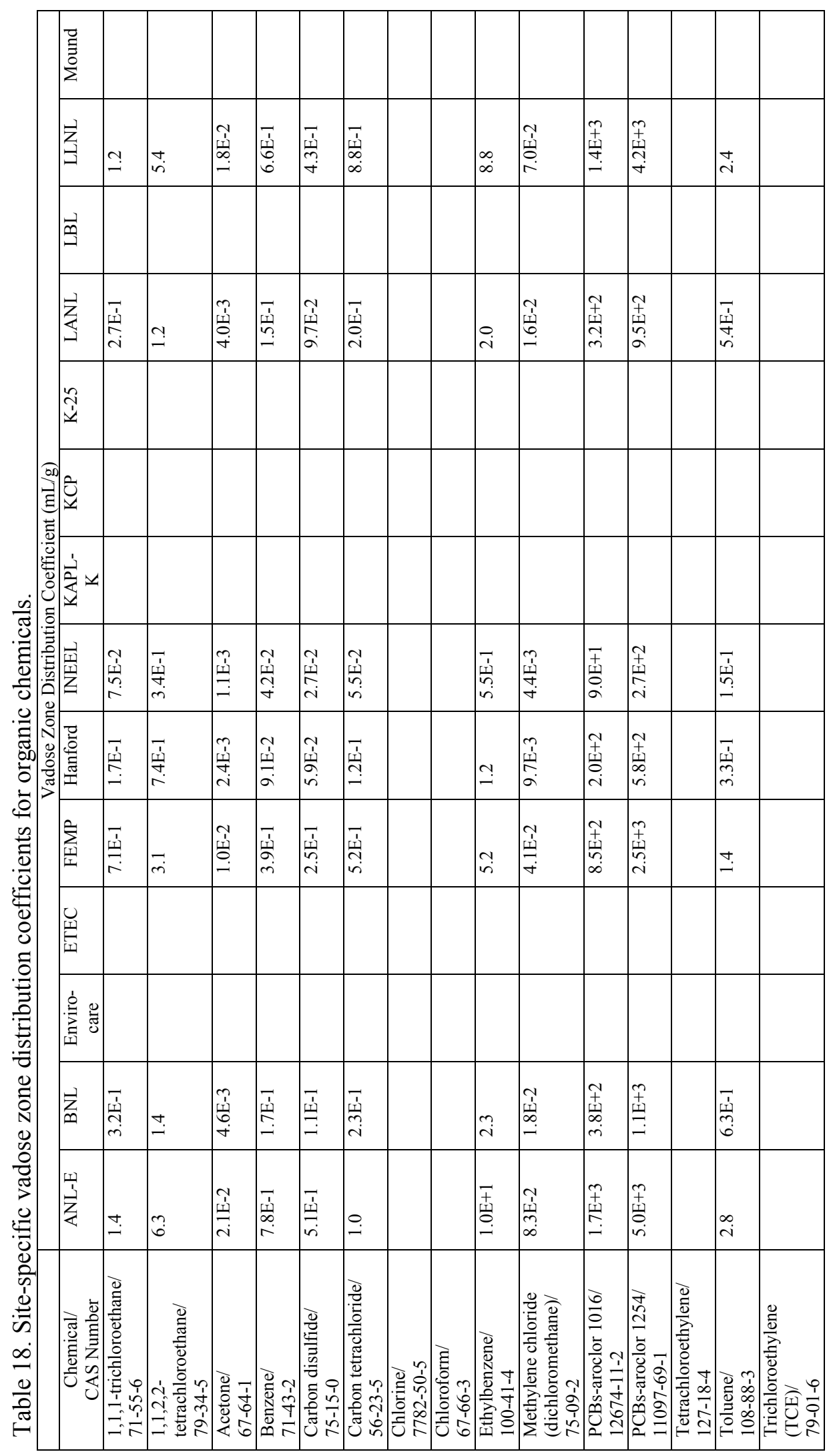




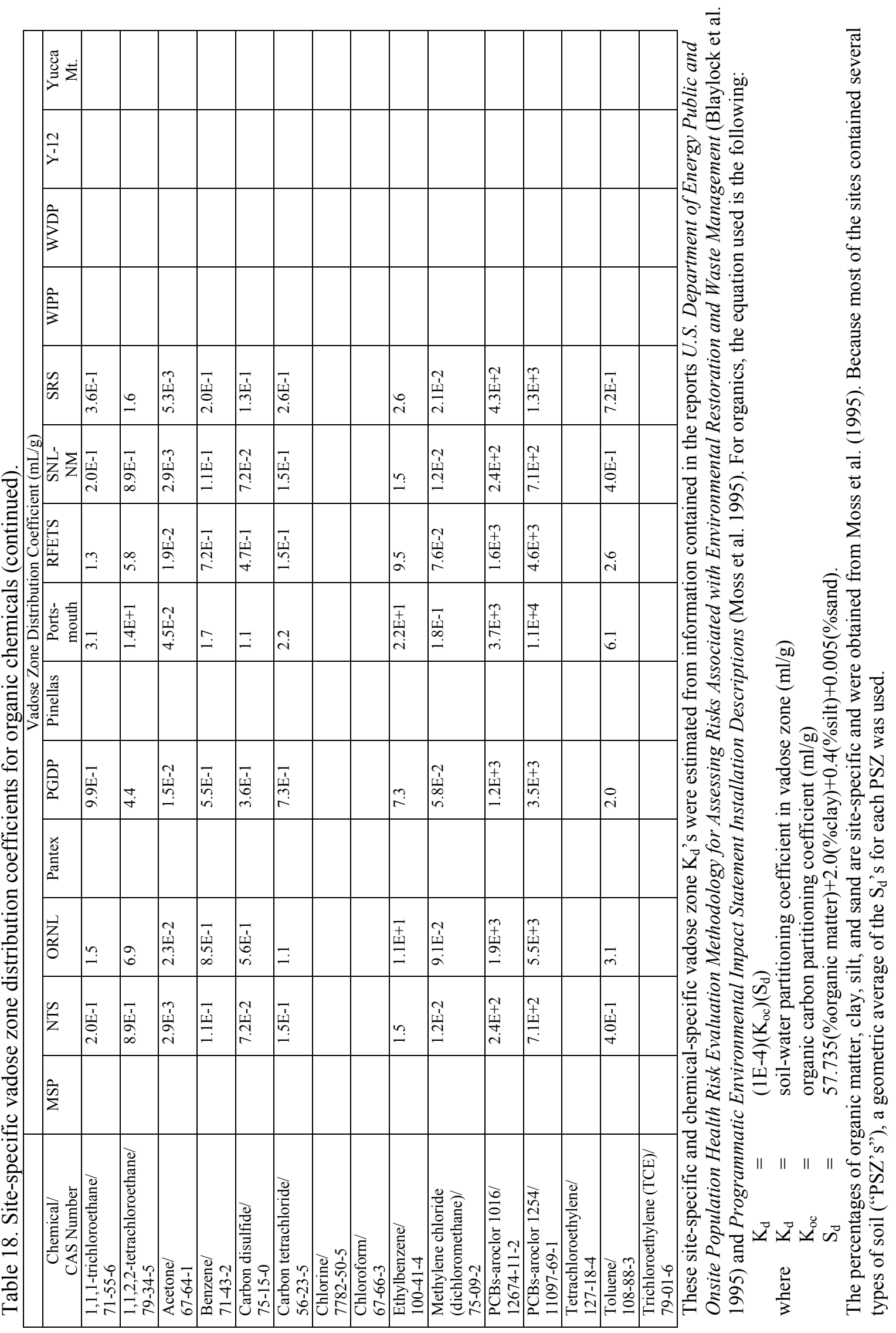




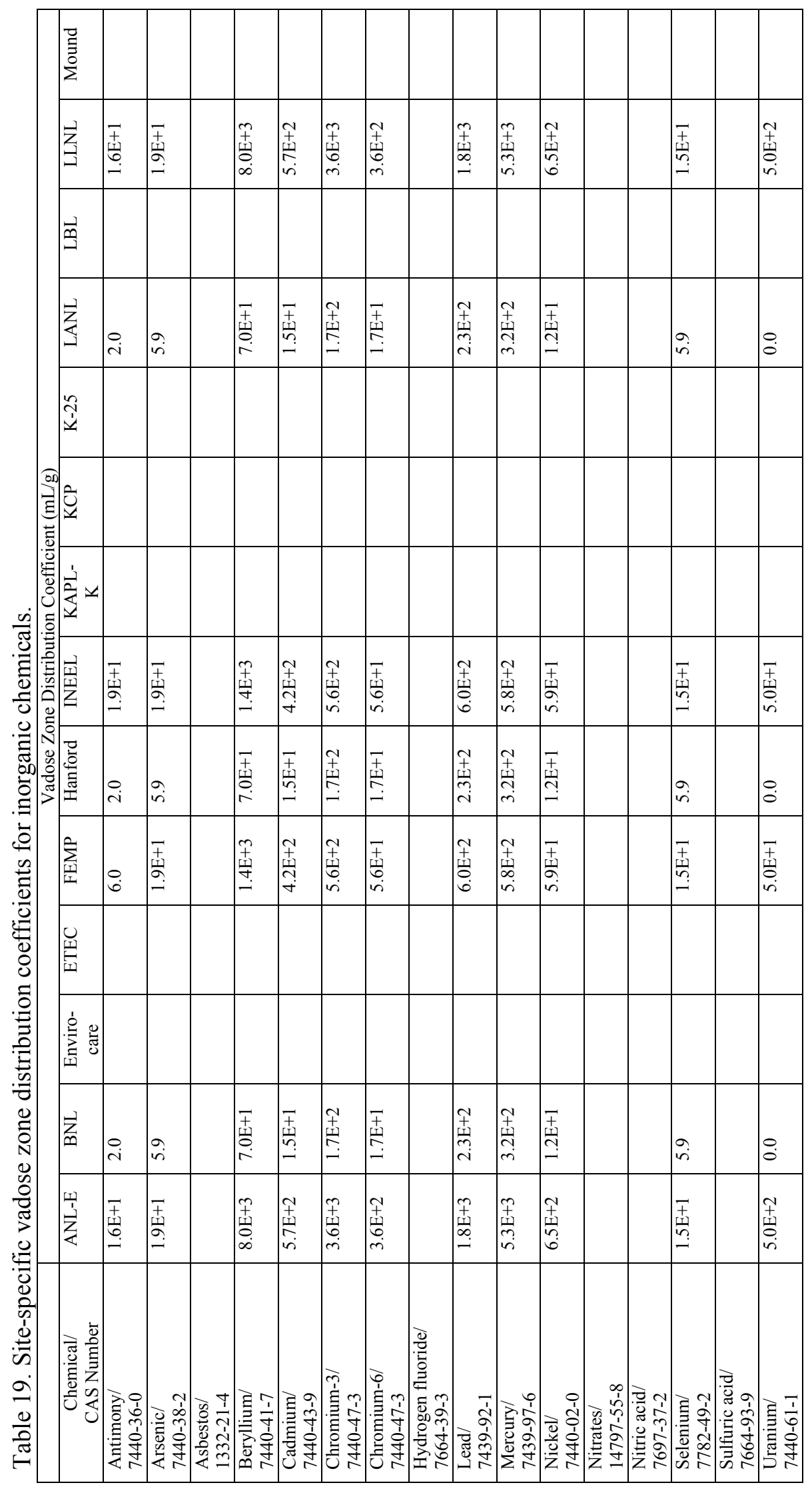




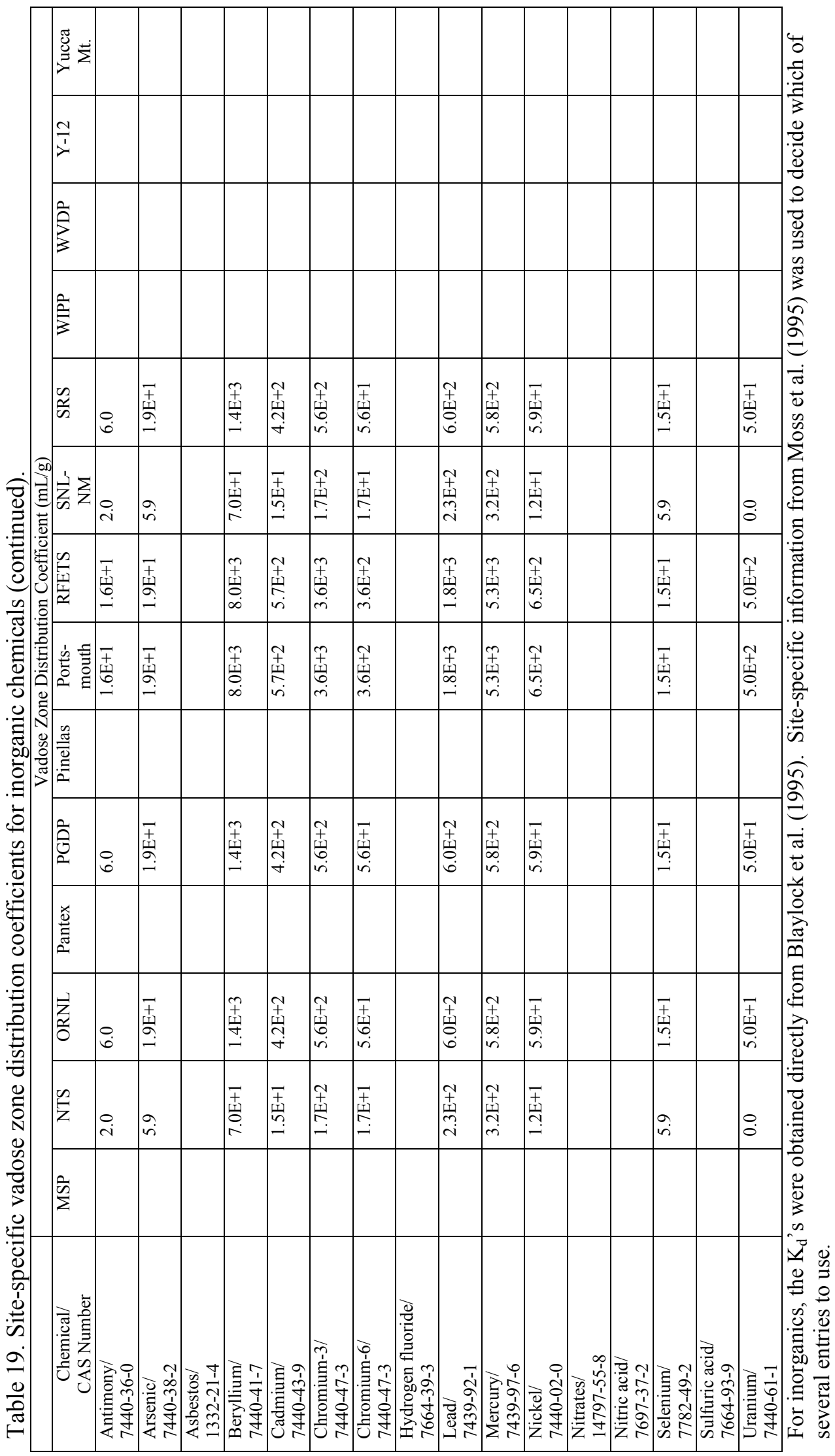




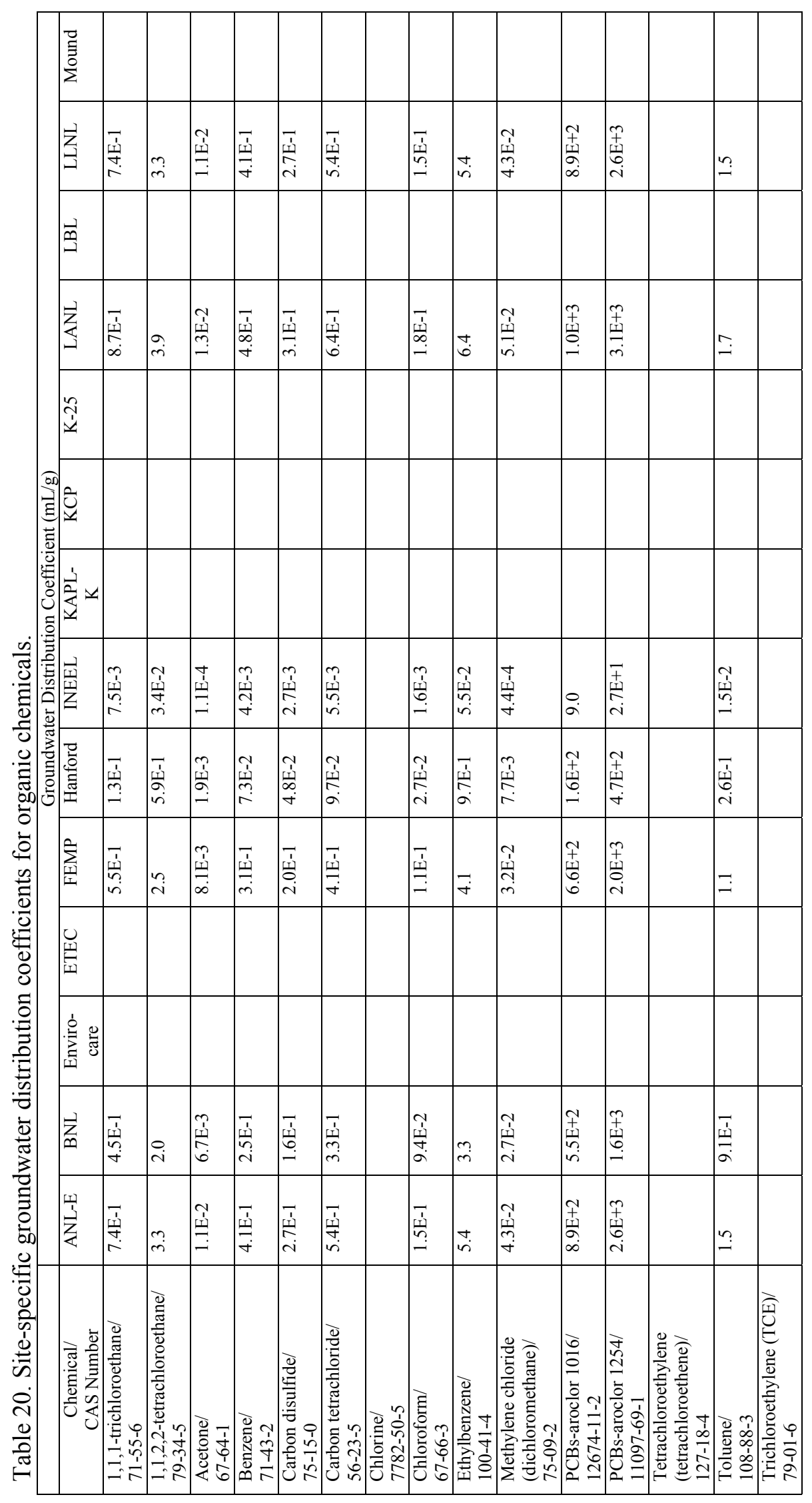




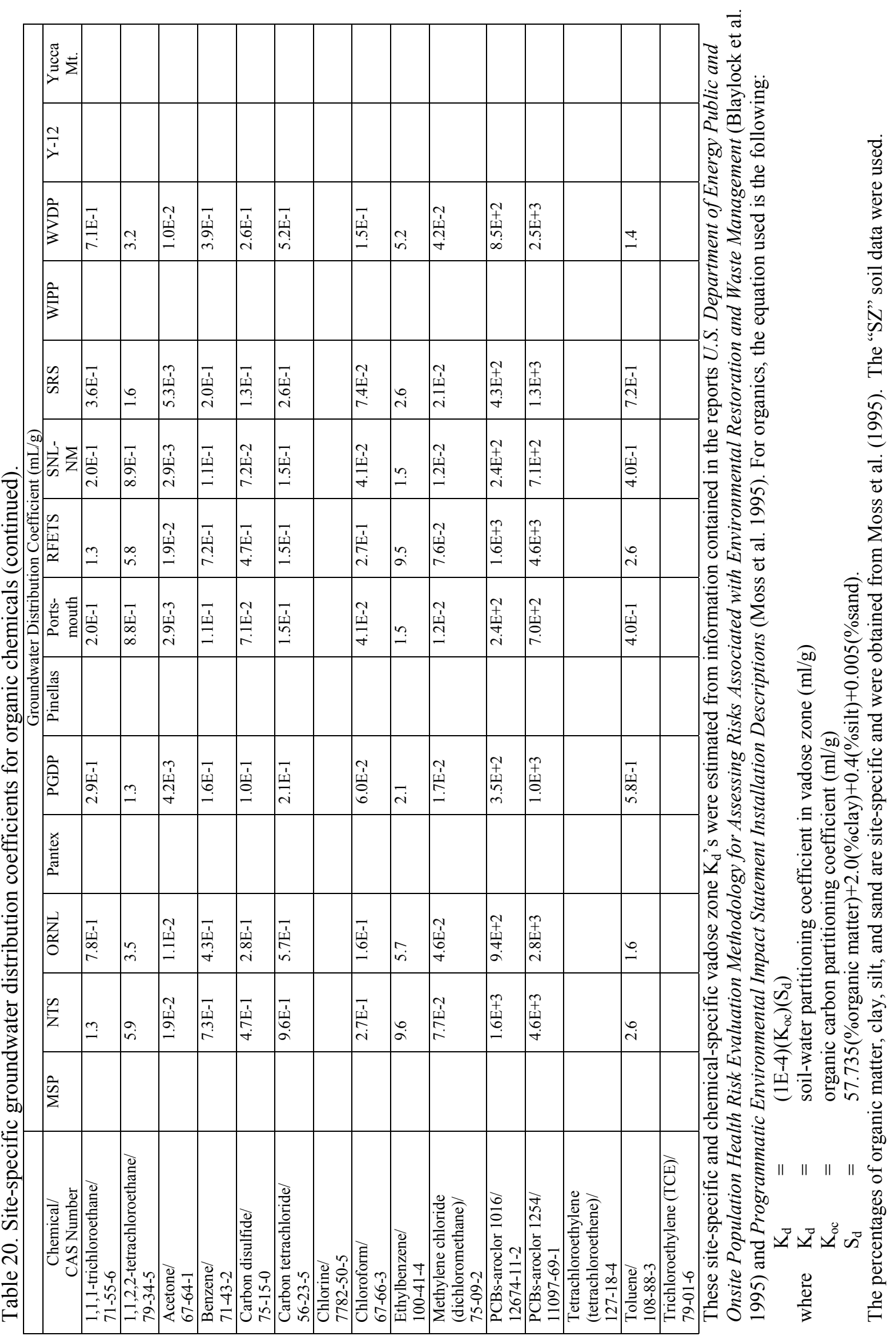




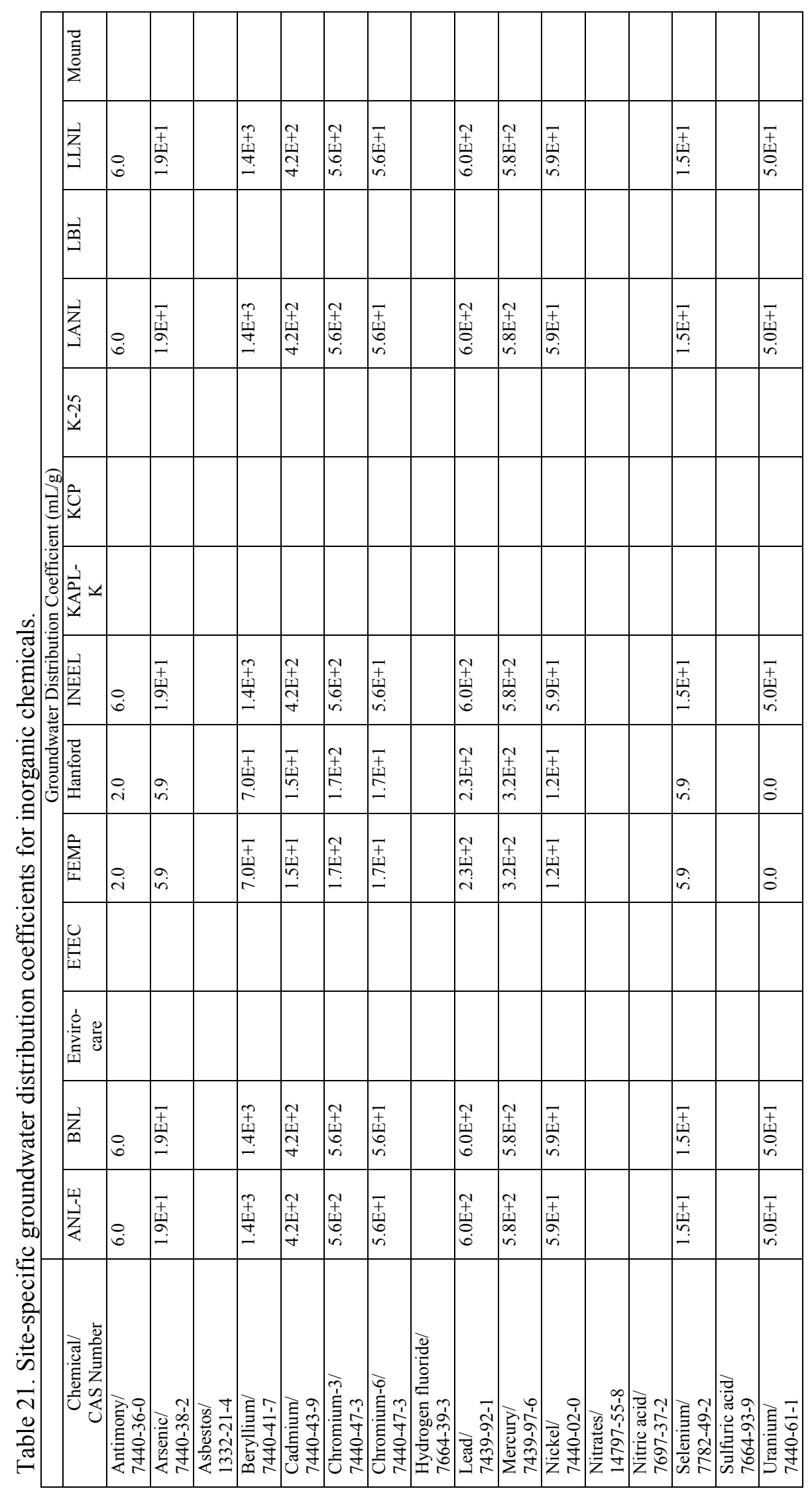




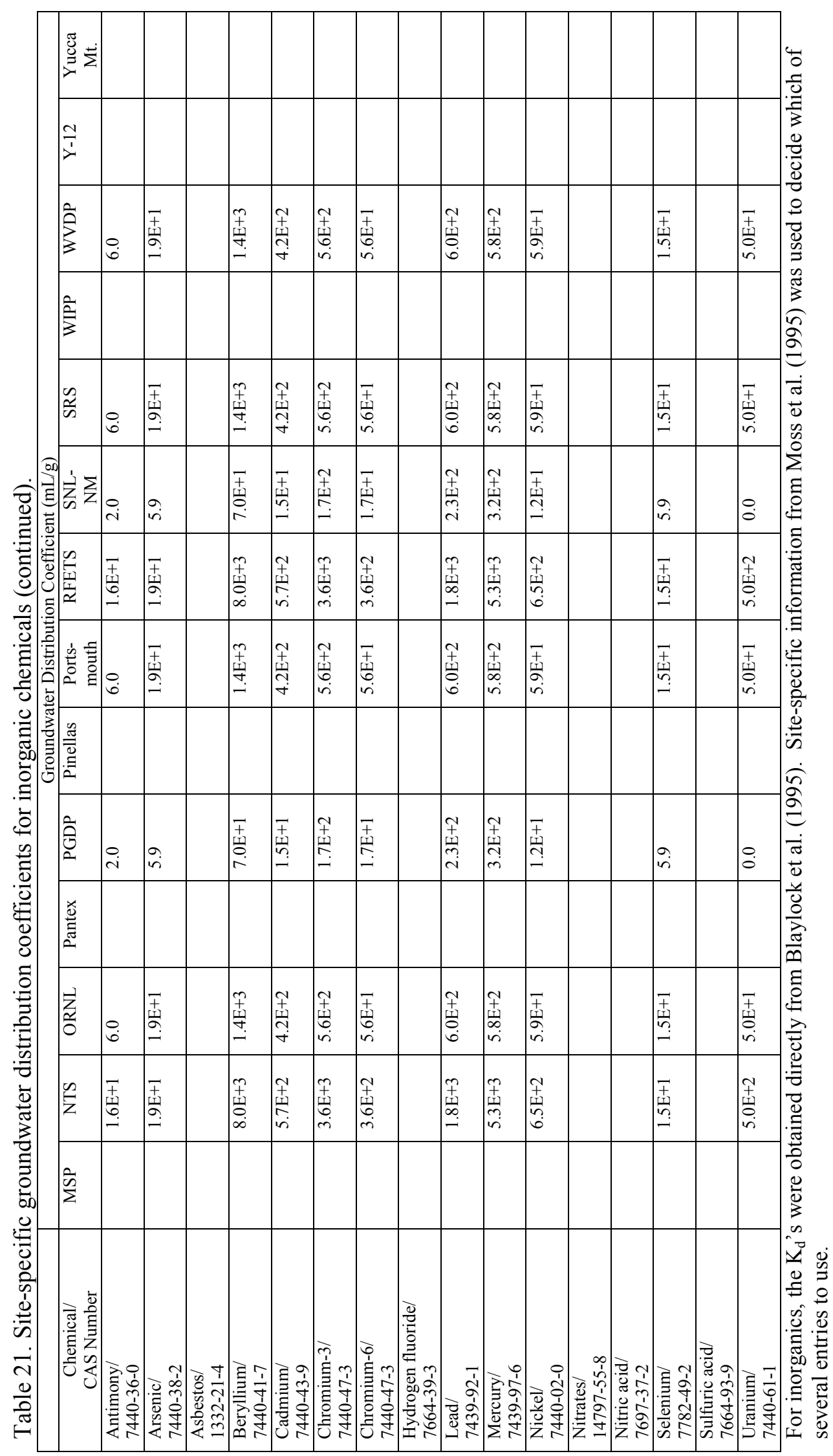




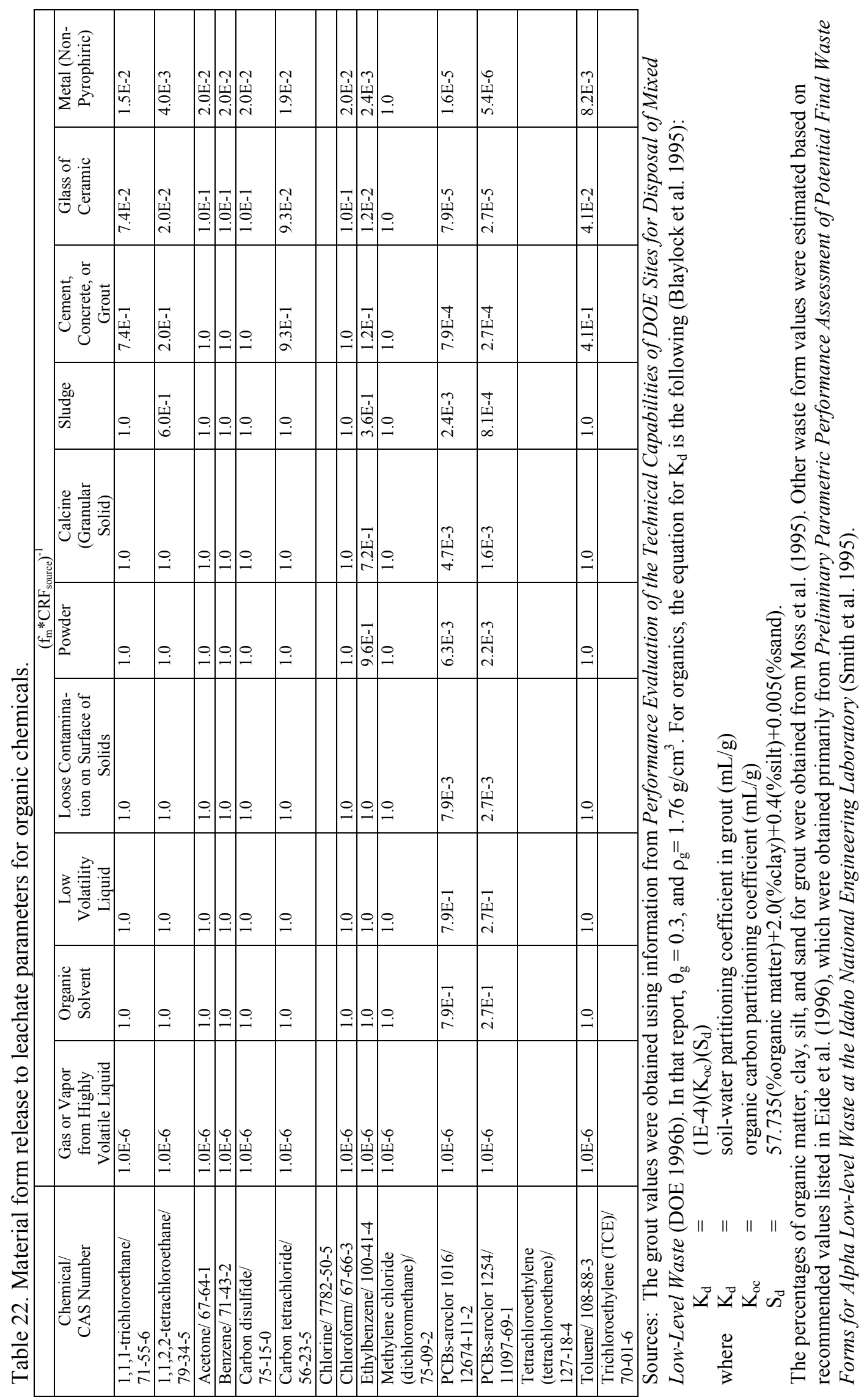




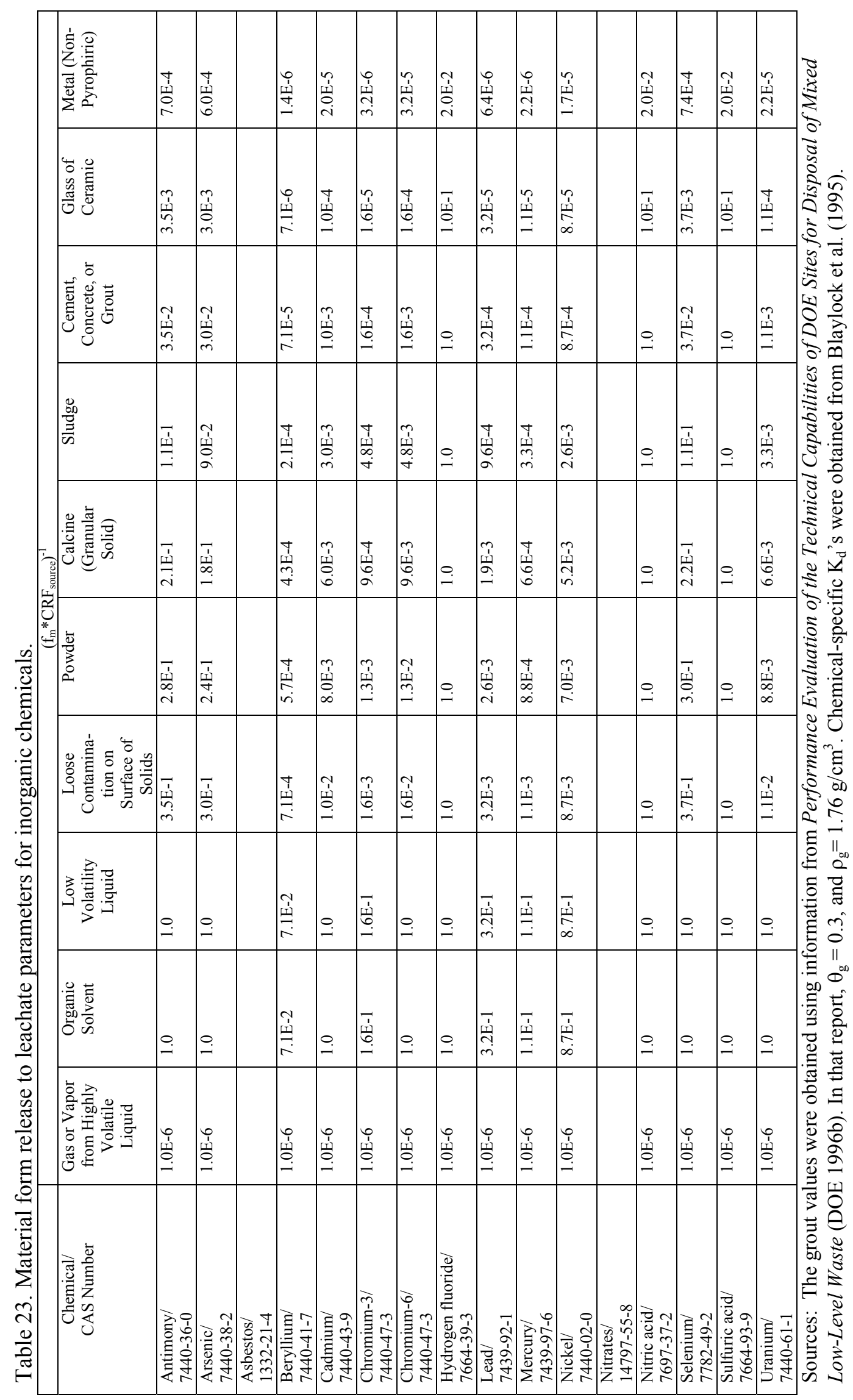




\subsection{Normal Exposure Model}

The normal exposure model consists of an off-gas exposure contribution and a normal radiation exposure contribution. Off-gas exposure is modeled for other site workers and the public. It is assumed that workers at the facility are not exposed to the off-gas. The off-gas risk equation for radionuclides and chemicals is the following:

$$
\text { Risk }_{\text {off-gas }} \quad=\quad(1 \mathrm{a})\left(1 \mathrm{a}_{\text {decay }}\right)(1 \mathrm{~b})(2 \mathrm{a})(2 \mathrm{~b})\left(4 * 5 \mathrm{~s}_{1-\mathrm{y}}+4 * 5 \mathrm{p}_{1-\mathrm{y}}\right)(7)
$$

where Risk off-gas $=\quad$ Risk to site personnel and the public within $80 \mathrm{~km}(50 \mathrm{mi})$ from
(1a)
$=$
$\left(1 \mathrm{a}_{\text {decay }}\right) \quad=\quad$ fractional decay of inventory
$=$ toxicity of inventory [rem/Ci or slope factor (chemicals), inhalation]
$=$ combination of MAR, DR, and respirable airborne release fraction (function of treatment process)
(2b) $\quad=\quad$ off-gas filter effectiveness
$\left(4 * 5 s_{1-\mathrm{y}}\right) \quad=$ unit $\mathrm{Ci}$ or $\mathrm{kg}$ exposure to other site workers resulting from atmospheric
$\left(4 * 5 \mathrm{p}_{1-\mathrm{y}}\right)$ dispersion and inhalation $\left(\mu \mathrm{Ci}_{\text {inhaled }} / \mathrm{Ci}_{\text {released }}\right.$ or $\left.\mathrm{mg}_{\text {inhaled }} / \mathrm{kg}_{\text {released }}\right)$ unit $\mathrm{Ci}$ or $\mathrm{kg}$ exposure to public risk and units conversion factor [latent cancer fatalities/rem or latent cancer fatalities/cancer incidence $/\left(\mathrm{kg}_{\text {body mass }}\right.$ - day $\left.)\right]$. inhalation of off-gas, actinides, nonactinides, or chemical (fatalities)

This equation is applied separately for actinides, nonactinides, and each chemical considered. With the conversion factor term (7), the risk units are fatalities for both radionuclides and chemicals. Values for (2a) range from $1 \mathrm{E}-2$ for energetic treatment processes to $5 \mathrm{E}-4$ for venting or sorting/repackaging activities, and 1.0E-6 for capping of disposal facilities (Table 24). The filter effectiveness, (2b), is assumed to be 1E-4 (1.0E-2 for D\&D activities), unless the process does not include a filter (Table 24). Also, for waste located underground, the term $(2 \mathrm{~b})$ is modified by a depth correction factor [Equation (6)]. The exposure terms $\left(4 * 5 \mathrm{~s}_{1-\mathrm{y}}\right)$ and $\left(4 * 5 \mathrm{p}_{1-\mathrm{y}}\right)$ were determined for each DOE site from unit Ci atmospheric release and exposure calculations performed for the Waste Management Programmatic Environmental Impact Statement, or WM-PEIS (DOE/EIS-0200-F, May 1997). Results for one-year releases were used (Table 11). The one-year release results are considered to be best estimate, so no conversion from $95 \%$ meteorological conditions is needed.

Normal radiation exposure to involved workers (those workers assigned to the facility that actually work with the hazardous material) is modeled using the following equation:

$$
\begin{aligned}
\text { Risk }_{\text {rem }}=\quad & \text { (\#involved workers } \\
& (\text { large facility })\left(\text { volume }_{\text {velume }} \text { large facility }^{0.33}(6)\right. \\
& \text { (multiplier } 1)(\text { multiplier2 })
\end{aligned}
$$

$\begin{array}{lll}\text { where Risk }_{\text {rem }} & = & \begin{array}{l}\text { Risk to facility workers from direct radiation during normal operation } \\ \text { (fatalities) }\end{array} \\ (6) & = & \text { actual time }(\mathrm{y}) \text { to perform activity } \\ \left(1 \mathrm{a}_{\text {decay }}\right) & = & \mathrm{Ci}(\text { decayed)/Ci (original amount) } \\ \text { YREXPW } & = & \text { yearly radiation exposure to involved workers, } 0.075 \mathrm{rem} / \mathrm{y} \\ \text { multiplier1 } & = & 1.0 \text { (most activities), } 0.5 \text { (storage) } 0.1 \text { (underground storage) } \\ \text { multiplier2 } & = & 0.1 \text { (activities not near the waste) }\end{array}$ 
The exposure rate of $0.075 \mathrm{rem} / \mathrm{y}$ for involved workers reflects DOE experience for the years $1996-2000$ for workers with measurable doses (DOE 2001a). The Ci/V term accounts for waste streams with higher or lower than normal radiation levels. Because of the decay term in Equation (17), an activity that is started immediately will result in higher normal exposure than an activity that is started later when some of the radioactivity has decayed. (Normal exposure is assumed to scale with the decayed $\mathrm{Ci}$.)

Normal exposure is also assumed to scale with the concentration, $\mathrm{Ci} / \mathrm{V}$, of the material in question. Reference values for $\mathrm{Ci} / \mathrm{V}$ are listed in Table 25.

It is assumed that noninvolved workers receive no significant exposure. Also, normal radiation exposure during transportation is covered in Section 3.9.

Table 24. Off-gas exposure model parameters for activities.

\begin{tabular}{|c|c|c|c|c|}
\hline Activity Category & Activity Type & Activity & $\begin{array}{l}\text { MAR, DR, and } \\
\text { RARF term (2a) }\end{array}$ & Filter Effectiveness \\
\hline \multirow{6}{*}{$\begin{array}{l}\text { Waste/Material } \\
\text { Management }\end{array}$} & Treatment & Venting & $5.0 \mathrm{E}-4$ & $1.0 \mathrm{E}-4$ \\
\hline & & Sort/Repackage & $5.0 \mathrm{E}-4$ & $1.0 \mathrm{E}-4$ \\
\hline & & Waste Preparation & $1.0 \mathrm{E}-3$ & $1.0 \mathrm{E}-4$ \\
\hline & & $\begin{array}{l}\text { Low Energy } \\
\text { Treatment }\end{array}$ & $1.0 \mathrm{E}-3$ & $1.0 \mathrm{E}-4$ \\
\hline & & $\begin{array}{l}\text { Moderate Energy } \\
\text { Treatment }\end{array}$ & $5.0 \mathrm{E}-3$ & $1.0 \mathrm{E}-4$ \\
\hline & & $\begin{array}{l}\text { High Energy } \\
\text { Treatment }\end{array}$ & $1.0 \mathrm{E}-2$ & $1.0 \mathrm{E}-4$ \\
\hline \multirow{6}{*}{$\begin{array}{l}\text { Environmental } \\
\text { Restoration }\end{array}$} & Capping & Capping & $1.0 \mathrm{E}-6$ & $1.0 \mathrm{E}-1 *$ depth factor ${ }^{\mathrm{a}}$ \\
\hline & In-situ Treatment & $\begin{array}{l}\text { Low Energy } \\
\text { Treatment }\end{array}$ & $1.0 \mathrm{E}-3$ & $1.0 \mathrm{E}-4 *$ depth factor ${ }^{\mathrm{a}}$ \\
\hline & & $\begin{array}{l}\text { Moderate Energy } \\
\text { Treatment }\end{array}$ & $5.0 \mathrm{E}-3$ & $1.0 \mathrm{E}-4 *$ depth factor ${ }^{\mathrm{a}}$ \\
\hline & & $\begin{array}{l}\text { High Energy } \\
\text { Treatment }\end{array}$ & $1.0 \mathrm{E}-2$ & $1.0 \mathrm{E}-4 *$ depth factor ${ }^{\mathrm{a}}$ \\
\hline & Extraction & $\begin{array}{l}\text { Vapor Vacuum } \\
\text { Extraction }\end{array}$ & $5.0 \mathrm{E}-4$ & $1.0 \mathrm{E}-4$ \\
\hline & & Pump and Treat & $5.0 \mathrm{E}-4$ & $1.0 \mathrm{E}-4$ \\
\hline \multirow[t]{9}{*}{ D\&D } & Removal & $\begin{array}{l}\text { Loose/Fixed } \\
\text { Hazardous Waste } \\
\text { Removal }\end{array}$ & $1.0 \mathrm{E}-2$ & $1.0 \mathrm{E}-2$ \\
\hline & & $\begin{array}{l}\text { Loose Radioactive } \\
\text { Material Removal }\end{array}$ & $1.0 \mathrm{E}-2$ & $1.0 \mathrm{E}-2$ \\
\hline & & $\begin{array}{l}\text { Removal of Fixed } \\
\text { Contamination }\end{array}$ & $1.0 \mathrm{E}-2$ & $1.0 \mathrm{E}-2$ \\
\hline & & $\begin{array}{l}\text { Irradiated Structure } \\
\text { Removal }\end{array}$ & $1.0 \mathrm{E}-2$ & $1.0 \mathrm{E}-1$ \\
\hline & & $\begin{array}{l}\text { Buried Pipe } \\
\text { Removal }\end{array}$ & $1.0 \mathrm{E}-2$ & 1.0 \\
\hline & & Soil Removal & $1.0 \mathrm{E}-2$ & 1.0 \\
\hline & Decontamination & Decontamination & $1.0 \mathrm{E}-2$ & $1.0 \mathrm{E}-2$ \\
\hline & Entombment & Entombment & $5.0 \mathrm{E}-4$ & $1.0 \mathrm{E}-2$ \\
\hline & Demolition & Demolition & $1.0 \mathrm{E}-3$ & 1.0 \\
\hline
\end{tabular}

a. The depth factor is given by Equation (6). 
Table 25. Reference Ci/V concentrations for waste/material categories.

\begin{tabular}{|l|l|}
\hline \multicolumn{1}{|c|}{ Waste Category } & Reference $\mathrm{Ci} / \mathrm{V}\left(\mathrm{Ci} / \mathrm{m}^{3}\right)$ \\
\hline SNF & $1 \mathrm{E}+6$ \\
\hline HLW & $5 \mathrm{E}+3$ \\
\hline CH-TRUW & 5 \\
\hline RH-TRUW & $5 \mathrm{E}+2$ \\
\hline LLW/MLLW & 5 \\
\hline SNM & 1 \\
\hline
\end{tabular}

\subsection{Standard Industrial Risk Model}

Standard industrial risk is defined as the risk from accidents such as falls, explosions, burns, heat exposure, etc. while involved in waste management or environmental restoration activities. The risk is measured in fatalities. However, if risks are converted to dollars, then the dollar impacts of injuries, lost workdays, etc. are also included. The conversion from fatalities to dollars is discussed in Section 3.11. Standard industrial risk for transportation is addressed in Section 3.9.

ESHRAP distinguishes two types of workers: involved and support. Involved workers are those who actually work with the waste, while support personnel provide office and managerial support. Estimates of the numbers of involved workers associated with the various large size activities are presented in Table 2. In general, the numbers of support personnel are assumed equal to the number of involved workers, as discussed in Section 3.3. These worker estimates are then modified by the actual size of the activity, as indicated in Equations (1) and (2).

Standard industrial fatalities are estimated by determining the total worker hours associated with an activity and multiplying the hours by a death rate. The total worker hours are determined by multiplying the number of workers by the activity duration and converting from worker years to worker hours $(2000 \mathrm{~h} / \mathrm{y})$. Two standard industrial death rates (for involved and support workers) have been estimated from DOE experience, using statistical analyses of the data contained in CAIRS (DOE 2001b). In that database, data are presented for eight different operation codes: (1) government, (2) production, (3) research, (4) service, (5) cost construction, (7) architectural/ engineering, (8) oil and gas, and (9) security and protective forces. Because two different death rates were needed (for involved and support workers), the data from these eight operation codes were analyzed to identify to identify "high rate" and "low rate" groups. Operation codes (2), (3), (4), (5), (8), and (9) were then assigned to the "high rate" group and operation codes (1) and (7) to the "low rate" group. Trend analyses were then performed within each group for the years $1995-2000$. For the "high rate" group, no trend was identified, and the death rate (SIDRATE) is $8.6 \mathrm{E}-9$ fatality $/ \mathrm{h}$, based on 13 fatalities and $1.52 \mathrm{E}+9$ worker hours. This rate is used for involved workers. For the "low rate" group, there were no fatalities during the period $1995-2000$ $(1.68 \mathrm{E}+8$ worker hours). The death rate for this group was estimated to be ten times lower, or $8.6 \mathrm{E}-10$ fatality/h. This rate is used for support workers. Both death rates are considered to be representative of DOE experience for the year 2000 and are considered to be best estimates.

\subsection{Transportation Model}

Risk from transportation of waste includes accidental release of waste/material into the atmosphere, exposure from incident-free operation, and standard industrial risk (fatalities resulting directly from a truck or rail accident or from crew accidents not related to a vehicle accident). Accidental release of waste/material to the atmosphere, resulting from vehicle accidents, is modeled using the accidental release model discussed in Section 3.5. However, in Equation (4) in that section, the product of terms (3) and (6) is the number of accidents occurring during the activity lifetime. For transportation, that product is replaced by a vehicle accident rate per kilometer multiplied by the total number of kilometers traveled 
with a waste/material cargo. Also, the containment failure probability term (2b) now represents a weighted average obtained from a variety of accident severity categories. Various transportation parameters are summarized in Table 26.

Table 26. Summary of selected transportation model parameters.

\begin{tabular}{|c|c|c|c|c|c|}
\hline $\begin{array}{c}\text { Waste } \\
\text { Category }\end{array}$ & $\begin{array}{c}\text { Transportation } \\
\text { Mode }\end{array}$ & $\begin{array}{c}\text { Shipping Cask } \\
\text { Type }\end{array}$ & $\begin{array}{l}\text { Containment } \\
\text { Failure } \\
\text { Probability } \\
\text { (term 2b) }\end{array}$ & $\begin{array}{l}\text { Shipment Volume } \\
\left(\mathrm{m}^{3}\right)\end{array}$ & $\begin{array}{l}\text { Average } \\
\text { Speed } \\
(\mathrm{km} / \mathrm{h})\end{array}$ \\
\hline \multirow{2}{*}{ SNF } & Truck & Type B & $2.3 \mathrm{E}-4$ & $0.5^{\mathrm{a}}$ & 80 \\
\hline & Rail & Type B & $2.7 \mathrm{E}-4$ & $4.0 / \mathrm{car}^{\mathrm{a}}$ & 80 \\
\hline \multirow[t]{2}{*}{ HLW } & Truck & Type B & $6.3 \mathrm{E}-3$ & $\begin{array}{l}1.0 \\
(1 \text { canister/cask } \\
\text { and } 1 \text { cask/truck) }\end{array}$ & 80 \\
\hline & Rail & Type B & $5.6 \mathrm{E}-3$ & $\begin{array}{l}5.0 / \text { car } \\
(5 \text { canisters/cask, } 1 \\
\text { cask/car) }\end{array}$ & 80 \\
\hline \multirow[t]{2}{*}{ CH-TRUW } & Truck & TRUPACT-II & $2.3 \mathrm{E}-3$ & $\begin{array}{l}7.4 \\
(35 \text { drums/ } \\
\text { truck) }{ }^{b}\end{array}$ & 80 \\
\hline & Rail & TRUPACT-III & $1.0 \mathrm{E}-3$ & $\begin{array}{l}34.2 / \text { car } \\
(3 \text { casks } / \text { car })^{b}\end{array}$ & 80 \\
\hline \multirow[t]{2}{*}{ RH-TRUW } & Truck & RH-72B & $2.1 \mathrm{E}-3$ & $\begin{array}{l}0.9 \\
(1 \text { cask/truck }\end{array}$ & 80 \\
\hline & Rail & RH-72B & $1.1 \mathrm{E}-3$ & $\begin{array}{l}1.8 / \text { car } \\
(2 \text { casks/car })\end{array}$ & 80 \\
\hline \multirow[t]{2}{*}{$\begin{array}{l}\text { LLW/ } \\
\text { MLLW }\end{array}$} & Truck & Type A (drums) & $3.1 \mathrm{E}-2$ & $\begin{array}{l}12.0 \\
(60 \text { drums/truck })\end{array}$ & 80 \\
\hline & Rail & Type A (drums) & $4.1 \mathrm{E}-2$ & $\begin{array}{l}30.0 / \text { car } \\
\text { (150 drums/car) }\end{array}$ & 80 \\
\hline \multirow[t]{2}{*}{$\overline{\mathrm{SNM}}$} & Truck & Type A (cans) & $3.1 \mathrm{E}-2^{\mathrm{c}}$ & $\begin{array}{l}0.1 \\
(10 \text { cans/truck })^{d}\end{array}$ & 80 \\
\hline & Rail & Type A (cans) & $4.1 \mathrm{E}-2^{\mathrm{c}}$ & $\begin{array}{l}0.25 / \text { car } \\
(25 \text { cans } / \text { car })^{d}\end{array}$ & 80 \\
\hline \multirow[t]{2}{*}{ Chemical } & Truck & Type A (drums) & $3.1 \mathrm{E}-2^{\mathrm{c}}$ & $\begin{array}{l}12.0 \\
(60 \text { drums/truck })^{d}\end{array}$ & 80 \\
\hline & Rail & Type A (drums) & $4.1 \mathrm{E}-2^{\mathrm{c}}$ & $\begin{array}{l}\text { 30.0/car } \\
(150 \text { drums/car })^{\mathrm{d}}\end{array}$ & 80 \\
\hline
\end{tabular}

Sources: DOE (1997a) unless otherwise noted for containment failure probabilities and shipment volumes. Accident frequencies from Saricks and Thompkins (1999). Average speed from DOE (1997b).

a. From DOE (2002c)

b. From the Transuranic Waste Performance Management Plan (DOE 2002b)

c. Assumed to be similar to LLW/MLLW transportation

d. Estimate

The total number of kilometers traveled for a transportation activity is determined from the total volume of waste/material to be transported, the shipment volume, and the route distance. ESHRAP shipment volumes were obtained mainly from DOE (1997a). However, more recent data for TRUW were used for CH-TRUW and RH-TRUW (DOE 2002a). Also, the SNF shipment volumes were obtained from DOE (1995). Given the total volume to be transported and the shipment volume, the total number of trips is the total volume divided by the shipment volume. Multiplying the number of trips by the route (oneway) distance gives the total one-way distance traveled. (One-way distance is used because the truck or train is carrying the waste/material only one way. The return trip is with an empty cargo.) Shipment route 
distances were obtained from DOE (1997a) but with updates reflected in DOE (1997b). These distances (for both truck and rail transport) are built into ESHRAP for a wide variety of DOE sites.

Accident rates for both truck and rail shipments were obtained from the report State-Level Accident Rates of Surface Freight Transportation: A Reexamination (Saricks and Thompkins 1999). A single, national accident rate (ARATE) is uses for truck shipments. That report lists truck accident rates by state and as a national average. The mean rate for truck interstate accidents is $3.2 \mathrm{E}-7 / \mathrm{km}$. (Almost all of the shipment routes involve interstate highways, so the interstate rate was used rather than the total rate that covers all types of highways.) Individual state rates range from $1.1 \mathrm{E}-7 / \mathrm{km}$ to $9.0 \mathrm{E}-7 / \mathrm{km}$. ESHRAP contains four choices for truck accident rates: high (10 times moderate rate), moderate (3.2E-7/km), low (moderate rate divided by 10), and N/A (accidents not considered). These accident rates are summarized in Table 27.

Table 27. Truck and rail accident rates.

\begin{tabular}{|l|l|l|l|}
\hline Mode of Transportation & Accident Rate Option & $\begin{array}{l}\text { Accident Rate (ARATE) } \\
\left(\mathrm{km}^{-1}\right)\end{array}$ & Comments \\
\hline Truck & High & $3.2 \mathrm{E}-6$ & 10 times moderate \\
\hline & Moderate & $3.2 \mathrm{E}-7$ & $\begin{array}{l}\text { Saricks and Thompkins } \\
(1999)\end{array}$ \\
\hline & Low & $3.2 \mathrm{E}-8$ & Moderate/10 \\
\hline Rail & N/A & 0.0 & \\
\hline & High & $6.1 \mathrm{E}-7 / \mathrm{car}$ & 10 times moderate \\
\hline & Moderate & $6.1 \mathrm{E}-8 / \mathrm{car}$ & $\begin{array}{l}\text { Saricks and Thompkins } \\
(1999)\end{array}$ \\
\hline & Low & $6.1 \mathrm{E}-9 / \mathrm{car}$ & Moderate/10 \\
\hline & N/A & 0.0 & \\
\hline
\end{tabular}

For rail shipments, accident rates are presented in terms of accidents per rail car kilometer. If a train has ten cars (including the engine and caboose), then a trip of $1000 \mathrm{~km}$ results in 10,000 car-km. Individual state accident rates vary widely, with western states generally having lower rates. The range is from $1.1 \mathrm{E}-8 / \mathrm{car}-\mathrm{km}$ to $4.0 \mathrm{E}-6 / \mathrm{car}-\mathrm{km}$. Because the individual state rates vary widely, the median rate of $6.1 \mathrm{E}-8 / \mathrm{car}-\mathrm{km}$ is used as a representative national value. This rate must be multiplied by the number of cars in the train. ESHRAP assumes three rail cars with an engine and caboose for dedicated rail shipments (DOE 1997b), but the user can change these assumptions. For such shipments, the accident rate is then multiplied by five (three rail cars, one engine, and one caboose) to obtain an accident rate per kilometer. Similar to truck transportation, ESHRAP contains four choices for rail accident rates, with the moderate rate being $6.1 \mathrm{E}-8 / \mathrm{car}-\mathrm{km}$. These rates are presented in Table 27.

Table 28 illustrates the approach used to estimate the term (2b) for TRUW truck transportation using TRUPACT-II shipping containers, using information summarized in DOE (1997). Transportation accidents are subdivided into eight categories, ranging in severity from mild to extreme, each with a probability of occurrence given an accident. Associated with each of these accident categories is the estimated fraction of radionuclides released to the atmosphere. This estimated fraction is the product of the terms (2a) and (2b). Summing the products for each of the eight categories gives the average respirable release fraction given a truck accident. This is product of the terms $(2 a)$ and $(2 b)$. The value for term (2a) is 2E-4 from DOE (1997). Therefore, to determine the effective term (2b), the total in Table 28, $4.6 \mathrm{E}-7$, is divided by the term $(2 \mathrm{a})$. Therefore, term $(2 \mathrm{~b})$ is $(4.6 \mathrm{E}-7) /(2.0 \mathrm{E}-4)=2.3 \mathrm{E}-3$ for TRUW transported by truck in TRUPACT-II containers. Similar calculations were performed for other types of waste and for rail, and the results are summarized in Table 26. 
Table 28. TRUW truck transportation (TRUPACT-II) accident categories and release fractions.

\begin{tabular}{|l|l|l|l|}
\hline Accident Category & $\begin{array}{l}\text { Fractional Occurrence for } \\
\text { Truck Transportation }\end{array}$ & $\begin{array}{l}\text { Fraction of Inventory } \\
\text { Released to Atmosphere in } \\
\text { Respirable Form }\end{array}$ & $\begin{array}{l}\text { Product of Fractional } \\
\text { Occurrence and Fraction } \\
\text { Released }\end{array}$ \\
\hline I & $5.5 \mathrm{E}-1$ & 0.0 & 0.0 \\
\hline II & $3.6 \mathrm{E}-1$ & 0.0 & 0.0 \\
\hline III & $7.0 \mathrm{E}-2$ & $8.0 \mathrm{E}-9$ & $5.6 \mathrm{E}-10$ \\
\hline IV & $1.6 \mathrm{E}-2$ & $2.0 \mathrm{E}-7$ & $3.2 \mathrm{E}-9$ \\
\hline V & $2.8 \mathrm{E}-3$ & $8.0 \mathrm{E}-5$ & $2.2 \mathrm{E}-7$ \\
\hline VI & $1.1 \mathrm{E}-3$ & $2.0 \mathrm{E}-4$ & $2.2 \mathrm{E}-7$ \\
\hline VII & $8.5 \mathrm{E}-5$ & $2.0 \mathrm{E}-4$ & $1.7 \mathrm{E}-8$ \\
\hline VIII & $1.5 \mathrm{E}-5$ & $2.0 \mathrm{E}-4$ & $3.0 \mathrm{E}-9$ \\
\hline & & & \\
\hline Total & 1.0 & Not applicable & $4.6 \mathrm{E}-7$ \\
\hline
\end{tabular}

Source: DOE (1997a)

An accident releasing radionuclides or chemicals into the atmosphere could occur anywhere along the shipment route. Values for the term $\left(4 * 5 p_{24-\mathrm{h}}\right)$ in Equation 4 could range from less than 1 to over 1000 (the range seen in Table 11 for 24-hour releases), depending upon the population density. A value of 50 is used for offsite transport, reflecting the fact that for typical shipment routes, most of the distance involves rural conditions. If the transport is entirely within a DOE site, then the value for that site (Table 11) is used.

Normal radiation risk (latent cancer fatality) to the crew and public from incident-free transportation is modeled using the following equation:

$$
\text { Risk } \quad=\quad(\mathrm{C})(\mathrm{X})\left(1 \mathrm{a}_{\text {decay }}\right)(\text { OWDIST)(NTRIPS)(NCARS)(7) }
$$

where Risk

$\mathrm{C}$

X $\quad=$

$\left(1 \mathrm{a}_{\text {decay }}\right)$

OWDIST

NTRIPS

NCARS

(7) $=\quad$ Risk to crew and public from normal radiation during incident-free transportation (fatalities)

$=\quad$ constant (function of waste type and mode of transport - truck or rail) [units of $(\mathrm{mrem} / \mathrm{h})^{-1}(\mathrm{rem} / \mathrm{km})$ ] radiation field at one meter outside cask (function of waste type) $(\mathrm{mrem} / \mathrm{h})$

$\mathrm{Ci}$ (decayed)/Ci (original)

one-way trip distance $(\mathrm{km})$

number of trips

1.0 for truck and number of waste transport cars per train for rail conversion from person-rem to latent cancer fatalities.

ESHRAP has default values for the constants $\mathrm{C}$ and $\mathrm{X}$. The constant $\mathrm{C}$ in this equation was calibrated using the more detailed transportation models and results in DOE (1997a and 1997b). Default values for $\mathrm{C}$ are summarized in Table 29. Also shown in Table 29 are default values for the radiation field one meter outside the case, X. These values were obtained from DOE (1997a), except for SNF and HLW. In DOE (1997a), an upper bound of the regulatory limit (14 mrem/h at one meter) was assumed for HLW shipments. To obtain a best estimate value, information was obtained from DOE (2002c). In that document, more realistic calculations indicate that the radiation field will be $60 \%$ of the regulatory limit. Therefore, $8 \mathrm{mrem} / \mathrm{h}$ at one meter is used. Likewise, DOE (2002c) assumed the upper bound regulatory limit for SNF shipments. However, that document indicated that a more realistic estimate would be $60 \%$ of the regulatory limit, similar to HLW. Therefore, $8 \mathrm{mrem} / \mathrm{h}$ is also used for SNF. Finally, Equation (18) predicts total normal radiation risk to both the crew and public. Results from DOE (1997b) were used to estimate the split of this total between the crew and public. 
Table 29. Transportation normal exposure parameters.

\begin{tabular}{|c|c|c|c|c|c|}
\hline \multirow[t]{2}{*}{ Waste Category } & \multicolumn{2}{|c|}{ Constant $\mathrm{C}\left[(\mathrm{mrem} / \mathrm{h})^{-1}(\mathrm{rem} / \mathrm{km})\right]$} & \multirow{2}{*}{$\begin{array}{c}\text { Radiation Field } \\
X \\
(\mathrm{mrem} / \mathrm{h} \text { at } 1 \mathrm{~m})\end{array}$} & \multicolumn{2}{|c|}{ Crew/Public Split for Exposure (\%) } \\
\hline & Truck & Rail & & Truck & Rail \\
\hline SNF & $4.7 \mathrm{E}-6$ & $1.6 \mathrm{E}-6$ & 8.0 & $15 / 85$ & $5 / 95$ \\
\hline HLW & $4.7 \mathrm{E}-6$ & $1.6 \mathrm{E}-6$ & 8.0 & $15 / 85$ & $5 / 95$ \\
\hline CH-TRUW & $1.9 \mathrm{E}-5$ & $9.3 \mathrm{E}-6$ & 3.0 & $15 / 85$ & $5 / 95$ \\
\hline RH-TRUW & $1.2 \mathrm{E}-5$ & $6.2 \mathrm{E}-6$ & 7.0 & $15 / 85$ & $5 / 95$ \\
\hline LLW/MLLW & $1.9 \mathrm{E}-5$ & $9.3 \mathrm{E}-6$ & 1.0 & $15 / 85$ & $5 / 95$ \\
\hline SNM & $6.2 \mathrm{E}-6$ & $3.1 \mathrm{E}-6$ & 0.5 & $15 / 85$ & $5 / 95$ \\
\hline
\end{tabular}

Sources: Constant C determined by matching predicted results with those from DOE (1997b) for CH-TRUW and RH-TRUW. Other values obtained from DOE (1997a), but with reductions similar to those observed for TRUW (between DOE 1997a and 1997b). Crew/public split of normal exposure also obtained from DOE (1997b). Radiation fields obtained from DOE (1997a), except for SNF and HLW (DOE 2002c). SNM values are estimates.

Standard industrial risk related to transportation includes both vehicle accidents and crew accidents (not related to vehicle accidents). Fatalities occurring because of vehicle accidents (not related to release of waste/material into the atmosphere) are estimated using the round-trip distance multiplied by the number of trips required for a transportation activity. Saricks and Thompkins (1999) indicate that there are 0.028 fatalities per truck accident on interstate freeways, and 0.37 fatalities per rail accident (median value because of the wide variation between states). Therefore, the number of fatalities from truck or rail accidents is the following:
Risk
$=$
(2)(OWDIST)(NTRIPS)(ARATE)(FPACC)

where Risk $\quad=$

ARATE

$=\quad$ crew and public risk from vehicle accidents (fatalities)

FPACC

$=\quad$ accident rate $($ accident $/ \mathrm{km})$

$=$ fatalities per accident.

To estimate crew standard industrial fatalities not related to vehicle accidents, the following equation is used:

Risk $\quad=\quad(2 \mathrm{crew} /$ truck $)(\mathrm{NTRIPS})[(2)(\mathrm{OWDIST}) /(\mathrm{SPEED})+\mathrm{TATIME}]$ (SIDRATE)

where Risk $\quad=\quad$ Standard industrial risk (not associated with vehicle accidents) to crew

$\begin{array}{lll}\text { SPEED } & = & \text { (fatalities) } \\ \text { TATIME } & = & \begin{array}{l}\text { average speed during trip, } 80 \mathrm{~km} / \mathrm{h}(\text { Table } 26) \\ \text { turnaround time during a round trip, } 16 \mathrm{~h} / \text { trip }\end{array} \\ \text { SIDRATE } & = & \begin{array}{l}\text { involved worker standard industrial death rate, } 8.6 \mathrm{E}-9 \text { fatality } / \mathrm{h} \\ (\text { Section 3.8). }\end{array}\end{array}$

Finally, transport of waste/material through piping is modeled as a process type of activity. The piping can be aboveground or buried. Activity parameters are listed in the tables associated with each type of exposure model.

\subsection{Disposal Model}

The disposal activity in ESHRAP evaluates human health risk from disposal facilities in their longterm post-closure state. The analysis can be performed assuming either institutional control or no 
institutional control following post closure. Three types of disposal facilities are included: LLW/MLLW surface and subsurface facilities, and SNF/HLW/TRUW deep geological repositories. Risks from a disposal facility before post-closure are covered by unloading and placement activities. However, standard industrial risks from construction of the disposal facility are included in the disposal activity.

Similar to other ESHRAP activities, the disposal activity requires inputs such as the type and volume of waste/material, start and end dates (these apply to the period of institutional control), type of disposal facility, etc. The risk analysis for disposal can cover any time period desired. Typically, disposal facility performance is evaluated over 1,000 or 10,000 years, depending upon the type of facility.

Additional facility inputs required by ESHRAP include fraction of area (where waste is placed) occupied by the waste, waste thickness (height), distance from surface to top of waste, and waste barrier lifetime. Standard values for disposal facilities contained in ESHRAP are summarized in Table 30.

Table 30. Disposal facility parameters.

\begin{tabular}{|l|l|l|l|l|}
\hline \multicolumn{1}{|c|}{ Disposal Facility } & $\begin{array}{c}\text { Fraction of } \\
\text { Disposal Area } \\
\text { Occupied by } \\
\text { Waste (f } f_{m}\end{array}$ & $\begin{array}{c}\text { Waste Thickness } \\
\text { (Height) (m) }\end{array}$ & $\begin{array}{c}\text { Distance from } \\
\text { Surface to Top of } \\
\text { Waste (m) }\end{array}$ & $\begin{array}{c}\text { Barrier (Cap and } \\
\text { Waste Container) } \\
\text { Lifetime (y) }\end{array}$ \\
\hline $\begin{array}{l}\text { Surface (Envirocare) } \\
(\text { LLW }\end{array}$ & 0.33 & 3 & 3 & 300 (cap) \\
\hline $\begin{array}{l}\text { Subsurface } \\
(\text { LLW/MLLW) }\end{array}$ & 0.67 & 3 & 3 & 300 (cap) \\
\hline $\begin{array}{l}\text { Deep Geological (WIPP) } \\
\text { (TRUW) }\end{array}$ & 0.12 & 3 & 660 & 50 (container) \\
\hline $\begin{array}{l}\text { Deep Geological (Yucca Mt.) } \\
\text { (SNF/HLW) }\end{array}$ & 0.01 & 1.65 & 300 & 5000 (container) \\
\hline
\end{tabular}

a. From the Envirocare website (Envirocare 2003)

b. From DOE (1996b)

c. From DOE (1997b)

d. From DOE (2002c)

Post-closure disposal risks evaluated by ESHRAP include natural phenomena resulting in radiological or chemical releases to the atmosphere, normal air entrainment (if the waste becomes uncovered), groundwater contamination, and various intrusion scenarios. However, if the waste is still covered, the depth correction factor [Equation (6)] reduces releases to the atmosphere from seismic events. (Range fires and strong winds are assumed to result in no releases to the atmosphere if the waste is covered.)

Disposal facility natural phenomena are listed in Table 31. Atmospheric dispersion and exposure to the public is modeled using Equation (4). Because the disposal facility activity covers only post closure, no site personnel or workers are assumed present. Frequency options include high, moderate, low, and not applicable (N/A). The frequencies associated with each option are shown in the table. Also presented are the MAR, DR, and term (2b) values. Because waste/material in disposal facilities is underground or covered with a cap, corrections are applied to DR and term (2b), as explained in Section 3.5.

For exposure to the public from normal air entrainment, Equation (16) is used, but with term (2a) replaced by a yearly fraction of waste entrained into the atmosphere, multiplied by the waste respirable fraction (from Table 8). Also, because an entrainment rate is used, the term (6) is also needed, along with the fraction of time the waste is exposed to the atmosphere. The revised equation is as follows:

$$
\text { Risk }_{\text {normal air entrainment }}=(1 \mathrm{a})\left(1 \mathrm{a}_{\text {decay }}\right)(1 \mathrm{~b})\left(\mathrm{ER} * \mathrm{RF} / \mathrm{h}_{\text {waste }}\right)\left(4 * 5 \mathrm{p}_{1-\mathrm{y}}\right)(6)(\mathrm{FRAC})(7)
$$




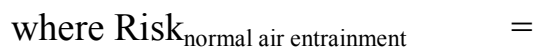

\section{(1a)}

$\left(1 \mathrm{a}_{\text {decay }}\right)$

(1b)

ER

RF

$\mathrm{h}_{\text {waste }}$

$\left(4 * 5 p_{1-y}\right)$

(6)

FRAC $=\quad$ Risk to public within $80 \mathrm{~km}(50 \mathrm{mi})$ from normal entrainment of radionuclides into the atmosphere (fatalities)

$=\quad$ inventory [curies (Ci's) or kg's (for chemicals)]

$=\quad$ fractional decay of inventory

$=\quad$ toxicity of inventory $[\mathrm{rem} / \mathrm{Ci}$ or slope factor (chemicals), inhalation]

$=\quad$ erosion or entrainment rate $(\mathrm{m} / \mathrm{y}$ of waste entrained $)$

$=$ respirable fraction

$=\quad$ height of waste $(\mathrm{m})$

$=$ unit $\mathrm{Ci}$ or kg exposure to public $\left(\mu \mathrm{Ci}_{\text {inhaled }} / \mathrm{Ci}_{\text {released }}\right.$ or $\left.\mathrm{mg}_{\text {inhaled }} / \mathrm{kg}_{\text {released }}\right)$

$=\quad$ duration of disposal facility post-closure period $(\mathrm{y})$

$=\quad$ fraction of post-closure period during which waste is exposed to atmosphere

$=\quad$ risk and units conversion factor [latent cancer fatalities/rem, latent cancer fatalities/cancer incidence $/\left(\mathrm{kg}_{\text {body mass }}\right.$ - day $\left.)\right]$.

Table 31. Disposal facility natural phenomena options.

\begin{tabular}{|c|c|c|c|c|c|}
\hline Event & Frequency Option & Frequency $\left(\mathrm{y}^{-1}\right)$ & MAR & $\mathrm{DR}^{\mathrm{a}}$ & $2 \mathrm{~b}(\mathrm{LPF})^{\mathrm{b}}$ \\
\hline \multirow[t]{4}{*}{ Range Fire } & High & $1.0 \mathrm{E}-1^{\mathrm{c}, \mathrm{d}}$ & 1.0 & $\begin{array}{l}1.0 * \mathrm{DR} \\
\text { correction factor }\end{array}$ & 1.0 \\
\hline & Moderate & $1.0 \mathrm{E}-2^{\mathrm{c}, \mathrm{d}}$ & 1.0 & $\begin{array}{l}1.0 * \mathrm{DR} \\
\text { correction factor }\end{array}$ & 1.0 \\
\hline & Low & $1.0 \mathrm{E}-3^{\mathrm{c}, \mathrm{d}}$ & 1.0 & $\begin{array}{l}1.0 * \mathrm{DR} \\
\text { correction factor }\end{array}$ & 1.0 \\
\hline & N/A & 0.0 & - & - & - \\
\hline \multirow[t]{4}{*}{ Seismic } & High & $1.0 \mathrm{E}-2$ & 1.0 & $\begin{array}{l}1.0 * \mathrm{DR} \\
\text { correction factor }\end{array}$ & $\begin{array}{l}1.0 * \text { depth } \\
\text { correction factor }\end{array}$ \\
\hline & Moderate & $1.0 \mathrm{E}-3$ & 1.0 & $\begin{array}{l}1.0 * \mathrm{DR} \\
\text { correction factor }\end{array}$ & $\begin{array}{l}1.0 * \text { depth } \\
\text { correction factor }\end{array}$ \\
\hline & Low & $1.0 \mathrm{E}-4$ & 1.0 & $\begin{array}{l}1.0 * \mathrm{DR} \\
\text { correction factor }\end{array}$ & $\begin{array}{l}1.0 * \text { depth } \\
\text { correction factor }\end{array}$ \\
\hline & N/A & 0.0 & - & - & - \\
\hline \multirow[t]{4}{*}{ Strong Wind } & High & $1.0 \mathrm{E}-2^{\mathrm{c}, \mathrm{d}}$ & 1.0 & $\begin{array}{l}1.0 * \mathrm{DR} \\
\text { correction factor }\end{array}$ & 1.0 \\
\hline & Moderate & $1.0 \mathrm{E}-3^{\mathrm{c}, \mathrm{d}}$ & 1.0 & $\begin{array}{l}1.0 * \mathrm{DR} \\
\text { correction factor }\end{array}$ & 1.0 \\
\hline & Low & $1.0 \mathrm{E}-4^{\mathrm{c}, \mathrm{d}}$ & 1.0 & $\begin{array}{l}1.0 * \mathrm{DR} \\
\text { correction factor }\end{array}$ & 1.0 \\
\hline & N/A & 0.0 & - & - & - \\
\hline \multirow[t]{4}{*}{ Normal Entrainment } & High & $5.0 \mathrm{E}-5 \mathrm{~m}^{\mathrm{c}, \mathrm{e}}$ & 1.0 & 1.0 & 1.0 \\
\hline & Moderate & $5.0 \mathrm{E}-6 \mathrm{~m}^{\mathrm{c}, \mathrm{e}}$ & 1.0 & 1.0 & 1.0 \\
\hline & Low & $5.0 \mathrm{E}-7 \mathrm{~m}^{\mathrm{c}, \mathrm{e}}$ & 1.0 & 1.0 & 1.0 \\
\hline & N/A & $0.0 \mathrm{~m}$ & - & - & - \\
\hline
\end{tabular}

a. See Section 3.5 following Table 9 for a discussion of the DR correction factor for waste located underground. The DR correction factor is $(0.1 \mathrm{~m} /$ waste thickness in meters $)$.

b. See Equation (6) and the accompanying text for a description of the depth correction factor for waste located underground.

c. These events apply only if the waste is exposed to the surface.

d. These frequencies are assumed to apply to a reference disposal facility with a footprint of $2.0 \mathrm{E}+5 \mathrm{~m}^{2}$. For other sizes of facilities, a correction factor (actual footprint $/ 2.0 \mathrm{E}+5 \mathrm{~m}^{2}$ ) is applied.

e. The frequency is actually a rate of waste entrainment into the atmosphere, expressed in terms of $\mathrm{m} / \mathrm{y}$ of waste (thickness) entrained. 
This equation is applied separately for actinides, nonactinides, and each chemical. Exposure to the general population is considered. For post-closure conditions, no site personnel or workers are assumed present. ESHRAP uses a simple soil entrainment rate $(\mathrm{m} / \mathrm{y}$ of soil cover entrained into the atmosphere), similar to the model used in DOE (1997b). This model is used to determine whether waste/material in a disposal facility will be uncovered in the future. The same model is used for waste entrainment ( $\mathrm{m} / \mathrm{y}$ entrained) once the waste is uncovered. DOE (1997b) lists site-specific soil entrainment rates ranging from 3.5E-7 to $7.7 \mathrm{E}-5 \mathrm{~m} / \mathrm{y}$. Based on this range, ESHRAP allows for four entrainment rate options: high ( $5 \mathrm{E}-5 \mathrm{~m} / \mathrm{y})$, moderate $(5 \mathrm{E}-6 \mathrm{~m} / \mathrm{y})$, low $(5 \mathrm{E}-7 \mathrm{~m} / \mathrm{y})$, and N/A $(0.0 \mathrm{~m} / \mathrm{y})$, as shown in Table 31 . The N/A option is used if the site in question is a net deposition area rather than an erosion area, or if the cap on the disposal facility is designed such that erosion cannot occur over the long term.

Population exposure to contaminated groundwater is considered. The groundwater pathway model is described in Section 3.6. With that model, release of radionuclides or chemicals from the waste does not start until the barrier lifetime (Table 30) has been exceeded. The pathway to the public is then through the vadose zone to the groundwater and then to drinking wells. Ten indicator radionuclides are considered (Table 4), along with specific chemicals chosen by the risk analyst.

Finally, three types of intrusion scenarios are considered: scavenger, residential, and drilling crew. The scavenger scenario involves a single person visiting the disposal site (post closure) to explore or scavenge. This scenario can occur many times over the analysis period for the disposal activity (typically 1,000 or 10,000 years). For the residential scenario, a family of four is assumed to live near the disposal site for period of years. Again, this scenario can occur many times over the analysis period. Drilling activities at the disposal facility are assumed to involve a crew of four and last five days. Selected exposure duration parameters associated with these three intrusion scenarios are presented in Table 31 . Scenario durations and numbers of people in Table 32 were obtained from DOE (1997b).

Table 32. Intrusion scenario exposure duration parameters.

\begin{tabular}{|c|c|c|c|c|}
\hline \multirow{2}{*}{$\begin{array}{l}\text { Intrusion } \\
\text { Scenario }\end{array}$} & \multicolumn{4}{|c|}{ Exposure Duration Parameters } \\
\hline & $\begin{array}{l}\text { Scenario Duration } \\
\text { (DUR) (y) }\end{array}$ & $\begin{array}{c}\text { Fraction of Time Near } \\
\text { Disposal Facility (FRCT1) }\end{array}$ & $\begin{array}{c}\text { Fraction of Time Near } \\
\text { Waste (FRCT2) }\end{array}$ & $\begin{array}{l}\text { Number of } \\
\text { People (NP) }\end{array}$ \\
\hline Scavenger & $\begin{array}{l}2.7 \mathrm{E}-3 \\
(24 \mathrm{~h}) \\
\end{array}$ & 1.0 & 1.0 & 1 \\
\hline Residential & $3.0 \mathrm{E}+1$ & 0.5 & 0.5 & 4 \\
\hline Drilling & $\begin{array}{l}6.8 \mathrm{E}-3 \\
(60 \mathrm{~h})\end{array}$ & 1.0 & 1.0 & 4 \\
\hline
\end{tabular}

Frequency options for the three intrusion scenarios are summarized in Table 33. The low frequency for drilling, 1.0E-5/y, was estimated from information in the report Preliminary Performance Assessment for the Waste Isolation Pilot Plant (SNL 1992). In Appendix 8 of that report, drilling activity near WIPP was estimated to be two boreholes per square mile over a period of 10,000 years. This estimate is for boreholes deep enough to penetrate the WIPP disposal unit, which is located $660 \mathrm{~m}$ below the surface. This converts to 7.7E-11 boreholes $/ \mathrm{m}^{2}-\mathrm{y}$. Assuming the ESHRAP standard disposal facility footprint of $2 \mathrm{E}+5 \mathrm{~m}^{2}$, this results in $1.5 \mathrm{E}-5 / \mathrm{y}$, which is rounded to $1.0 \mathrm{E}-5 / \mathrm{y}$. This value is assumed to be a low frequency because of the depth of the WIPP repository. Therefore, the moderate and high values are 10 and 100 times higher, respectively.

Exposure pathways for each intrusion scenario are summarized in Table 34. The natural phenomena releases to the atmosphere were discussed previously with respect to population exposure within $80 \mathrm{~km}$ $(50 \mathrm{mi})$. These releases can also result in exposure to people involved in the intrusion events. The same 
model is used, except that the term $\left(4 * 5 \mathrm{p}_{24-\mathrm{h}}\right)$ is replaced by the term $\left(4 * 5\right.$ intruder $\left._{24-\mathrm{h}}\right)$. To estimate the term ( $4 * 5$ intruder $\left._{24-\mathrm{h}}\right)$, Equation (10) was assumed to be applicable. This equation assumes that the intruders are $100 \mathrm{~m}$ from the release location, and that they require one hour before evacuating the area. However, the result, $0.022 \mu \mathrm{Ci}_{\text {inhaled }} / \mathrm{Ci}_{\text {released }}$-person, must be multiplied by the number of intruders and reduced by the fraction of the disposal activity duration during which the intruders are present. The result, applied to each of the three intrusion scenarios, is the following:

$$
\left(4 * 5 \text { intruder }_{24-\mathrm{h}}\right)=\left(\operatorname{Exp}_{100-\mathrm{m}}\right)(\mathrm{NP})(\mathrm{ISF})(\mathrm{DUR})(\mathrm{FRCT} 1)
$$

where $\left(4 *\right.$ intruder $\left._{24-\mathrm{h}}\right)=$

$\begin{array}{ll}\operatorname{Exp}_{100-\mathrm{m}} & = \\ \mathrm{NP} & = \\ \text { ISF } & = \\ \text { DUR } & = \\ \text { FRCT1 } & =\end{array}$

unit $\mathrm{Ci}$ or $\mathrm{kg}$ exposure to intruders resulting from accident atmospheric dispersion and inhalation $\left(\mu \mathrm{Ci}_{\text {inhaled }} / \mathrm{Ci}_{\text {released }}\right.$ or $\left.\mathrm{mg}_{\text {inhaled }} / \mathrm{kg}_{\text {released }}\right)$ result from Equation (10) $\left(\mu \mathrm{Ci}_{\text {inhaled }} / \mathrm{Ci}_{\text {released }}\right.$-person) number of people involved in intrusion event (Table 32) (person) intrusion scenario frequency (Table 33) $\left(\mathrm{y}^{-1}\right)$ duration of intrusion event (Table 32) (y) fraction of time near disposal facility (Table 32).

Table 33. Intrusion scenario frequency options.

\begin{tabular}{|l|l|l|}
\hline \multicolumn{1}{|c|}{ Intrusion Scenario } & Frequency Option & \multicolumn{1}{|c|}{ Frequency (ISF) $\left(\mathrm{y}^{-1}\right)^{\mathrm{a}}$} \\
\hline Scavenger & High & $1.0 \mathrm{E}+1$ \\
\hline & Moderate & 1.0 \\
\hline & Low & $1.0 \mathrm{E}-1$ \\
\hline & N/A & 0.0 \\
\hline Residential & High & $1.0 \mathrm{E}-2$ \\
\hline & Moderate & $1.0 \mathrm{E}-3$ \\
\hline & Low & $1.0 \mathrm{E}-4$ \\
\hline Drilling & N/A & 0.0 \\
\hline & High & $1.0 \mathrm{E}-3$ \\
\hline & Moderate & $1.0 \mathrm{E}-4$ \\
\hline & Low & $1.0 \mathrm{E}-5$ \\
\hline & N/A & 0.0 \\
\hline
\end{tabular}

a. Frequencies listed are for a disposal facility with a footprint of $2.0 \mathrm{E}+5 \mathrm{~m}^{2}$. For disposal facilities of other sizes, the frequency is multiplied by the factor (disposal facility footprint $) /\left(2.0 \mathrm{E}+5 \mathrm{~m}^{2}\right)$.

Table 34. Exposure pathways for intrusion scenarios.

\begin{tabular}{|l|l|l|l|l|l|}
\hline Intrusion Scenario & \multicolumn{5}{|c|}{ Exposure Pathway Modeled? } \\
\hline & $\begin{array}{c}\text { Natural } \\
\text { Phenomena } \\
\text { Releases to } \\
\text { Atmosphere }\end{array}$ & $\begin{array}{c}\text { Normal Wind } \\
\text { Entrainment to } \\
\text { Atmosphere }\end{array}$ & $\begin{array}{c}\text { Groundwater } \\
\text { Ingestion } \\
\text { Radiation }\end{array}$ & $\begin{array}{c}\text { Waste Brought } \\
\text { to Surface by } \\
\text { Drilling }\end{array}$ \\
\hline Scavenger & Yes & Yes & No & Yes & Yes \\
\hline Residential & Yes & Yes & Yes & Yes & Yes \\
\hline Drilling & Yes & Yes & No & Yes & Yes \\
\hline
\end{tabular}

Exposure from normal wind entrainment of waste is also modeled, as indicated in Table 34 . This exposure pathway exists only after the waste is exposed to the surface. The exposure model for the population within $80 \mathrm{~km}(50 \mathrm{mi})$, discussed previously in this section [Equation (21)], is also used for intruders, but with the term $\left(4 * 5 \mathrm{p}_{1-\mathrm{y}}\right)$ replaced by $\left(4 * 5\right.$ intruder $\left._{1-\mathrm{y}}\right)$. The term $\left(4 * 5\right.$ intruder $\left._{1-\mathrm{y}}\right)$ was estimated using Equation (10), but with " $1 \mathrm{~h}$ " replaced with " $24 \mathrm{~h}$ " to reflect the fact that no evacuation occurs:

$$
\begin{aligned}
\operatorname{Exp}_{100-\mathrm{m}, \text { normal }} & =(2.3 \mathrm{E}-3)\left(2.3 \mathrm{E}-4 \mathrm{~m}^{3} / \mathrm{s}\right)(1 \mathrm{E}+6 \mu \mathrm{Ci} / \mathrm{Ci})(24 \mathrm{~h} / 24 \mathrm{~h}) \\
& =0.53 \mu \mathrm{Ci}_{\text {inhaled }} / \mathrm{Ci}_{\text {released }} \text { intruder. }
\end{aligned}
$$


Similar to Equation (22), this result must be modified to account for the number of intruders and the fraction of post-closure time during which intruders are present. Also, an additional factor is required to reduce the 24-hour dispersion result to a one-year dispersion result. The resulting equation is the following:

\begin{tabular}{|c|c|c|}
\hline$\left(4 * 5\right.$ intruder $\left._{1-y}\right)$ & $=$ & $\left(\operatorname{Exp}_{100-\mathrm{m}, \text { normal }}\right)(\mathrm{NP})(\mathrm{ISF})(\mathrm{DUR})(\mathrm{FRCT} 1)(\mathrm{DISP})$ \\
\hline where $\left(4 *\right.$ sintruder $\left._{1-\mathrm{y}}\right)$ & $=$ & $\begin{array}{l}\text { unit } \mathrm{Ci} \text { or kg exposure to intruders resulting from normal atmospheric } \\
\text { dispersion and inhalation }\left(\mu \mathrm{Ci}_{\text {inhaled }} / \mathrm{Ci}_{\text {released }} \text { or } \mathrm{mg}_{\text {inhaled }} / \mathrm{kg}_{\text {released }}\right)\end{array}$ \\
\hline $\operatorname{Exp}_{100-m, n o r m a l}$ & $=$ & result from Equation $(23)\left(\mu \mathrm{Ci}_{\text {inhaled }} / \mathrm{Ci}_{\text {released }}\right.$-person $)$ \\
\hline NP & $=$ & number of people involved in intrusion event (Table 32) (person) \\
\hline ISF & $=$ & intrusion scenario frequency $($ Table 33$)\left(\mathrm{y}^{-1}\right)$ \\
\hline DUR & $=$ & duration of intrusion event (Table 32) (y) \\
\hline FRCT1 & $=$ & fraction of time near disposal facility (Table 32) \\
\hline DISP & $=$ & $\begin{array}{l}\text { ratio of } 1 \text {-y dispersion result to } 24-\mathrm{h} \text { result (approximately } 1 / 40 \text {, from } \\
\text { Table } 11 \text {, but site specific). }\end{array}$ \\
\hline
\end{tabular}

Only the residential intrusion scenario includes ingestion of groundwater, as indicated in Table 34. For this scenario, the groundwater pathway risk Equations (14) and (15) are used, but with the term $\left(4 * 5 \mathrm{p}_{\text {water }}\right)$ replaced with $\left(4 * 5\right.$ intruder $\left._{\text {water }}\right)$. Also, $\mathrm{FI}=1.0$. The term is the following:

$$
\left(4 * 5 \text { intruder }_{\text {water }}\right)=\quad(\mathrm{NP})(\text { GWRED })(\mathrm{ISF})(\mathrm{DUR})(\mathrm{FRCT} 1) .
$$

The term GWRED represents the reduction in water concentration at $100 \mathrm{~m}$ (a user input for the residential intrusion scenario) compared with the point where the waste enters the groundwater (Section 3.6). This risk occurs only after waste from the disposal unit reaches the groundwater and the well location. Before that time, the groundwater is not contaminated at the well location. The term (6) is the duration of the post-closure period for the disposal facility.

All three intrusion scenarios include direct radiation exposure. This model assumes an initial radiation field for the waste (before placement into the disposal facility). The radiation field is reduced with time as the radionuclides decay. Also, the radiation field is reduced by a depth factor, to account for a cover between the waste and the surface. Finally, the hours the intruders spend near the waste are calculated. Then the total exposure is just the radiation field seen by the intruders multiplied by the hours of exposure. The direct radiation exposure equation for each type of intrusion scenario is the following:

$$
\begin{array}{ll}
\text { Risk }_{\text {intruder,direct radiation }=\quad}(\mathrm{IRF})\left[\left(\mathrm{Ci}_{\text {original }} / \mathrm{V}_{\text {original }}\right) /(\mathrm{Ci} / \mathrm{V})_{\text {reference material }}\right]^{0.25}(1 \mathrm{a} \text {,decay }) \\
& \left(\mathrm{RED}_{\text {depth }}\right)(\mathrm{NP})(\mathrm{ISF})(\mathrm{DUR})(\mathrm{FRCT} 1)(\mathrm{FRCT} 2)(6)(7)(\mathrm{C})
\end{array}
$$

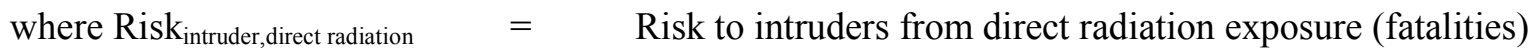

IRF

$\mathrm{RED}_{\text {depth }}$

$\mathrm{C}$ $\begin{array}{ll}= & \text { Risk to intruders from direct radiation exp } \\ = & \text { initial radiation field from waste }(\mathrm{mrem} / \mathrm{h})\end{array}$

$=\quad$ reduction in radiation field resulting from shielding from soil covering waste, $[1 /(1+\text { depth })]^{\mathrm{n}}$, where depth is soil cover above waste $(\mathrm{m})$, and $\mathrm{n}$ is 10

$=\quad$ duration of post-closure period for disposal facility $(\mathrm{y})$

$=\quad$ conversion factor (person-rem to latent cancer

fatalities)

$=\quad$ units conversion factor $(\mathrm{mrem} / \mathrm{h}$ to $\mathrm{rem} / \mathrm{y})$.

Table 35 presents initial radiation fields for various waste types. 
Table 35. Initial radiation fields for waste/material categories placed into disposal.

\begin{tabular}{|l|l|l|}
\hline \multicolumn{1}{|c|}{ Waste Category } & \multicolumn{1}{|c|}{ Waste Configuration $^{\text {a }}$} & \multicolumn{1}{|c|}{$\begin{array}{c}\text { Initial Radiation Field } \\
\text { at } 1 \mathrm{~m}(\text { IRF })(\mathrm{mrem} / \mathrm{h})\end{array}$} \\
\hline SNF & Rods & 50 \\
\hline & Debris & 100 \\
\hline HLW & Liquid, Calcine, or Glass & 1 \\
\hline CH-TRUW & Debris & 100 \\
\hline & Drums & 3 \\
\hline RH-TRUW & Debris & 10 \\
\hline & Drums & 10 \\
\hline LLW/MLLW & Debris & 50 \\
\hline & Drums & 3 \\
\hline SNM & Debris & 3 \\
\hline & Can & 1 \\
\hline
\end{tabular}

a. The debris configuration is used in disposal and legacy risk analyses (discussed in Section 4). In those analyses, the waste eventually degrades into debris, and with that configuration, there is less self-shielding. However, waste brought to the surface by drilling is also modeled as debris.

The drilling and residential scenarios include an additional risk element, the transport of buried waste to the surface from the drilling activity. (A residential scenario is assumed to also include the drilling of a well for drinking water.) This additional risk element is negligible if the waste in the disposal facility has already been uncovered (from normal entrainment of soil into the atmosphere), but can be important if the waste is still covered. The amount of waste transported to the surface from a borehole is just the area of the borehole multiplied by the height of the waste in the disposal facility times the factor $\mathrm{f}_{\mathrm{m}}$ (fraction of disposal area occupied by waste). Analysis of drilling scenarios for WIPP used a drill bit diameter of $0.35 \mathrm{~m}$ (DOE 1997b), while the Yucca Mountain analysis assumed a drill bit diameter of 0.21 $\mathrm{m}(\mathrm{DOE} 2002 \mathrm{c})$. In ESHRAP, a standard drill bit diameter of $0.25 \mathrm{~m}$ is assumed.

After the waste is transported to the surface, the scavenger, drilling crew, and residential family are exposed to direct radiation from the waste and normal entrainment of waste into the atmosphere. For the direct radiation calculation, the waste deposited on the surface is assumed to be mixed with soil and rock (from the drilling process) and have a thickness of $0.1 \mathrm{~m}$ (THDEBRIS) above the surface. A mixing reduction factor (MRF) of 0.1 is applied to the direct radiation field. Equation (26) is used, except that the term $\mathrm{RED}_{\text {depth }}$ defaults to 1.0 and the additional multiplier MRF is included. Also, an additional area reduction term is applied to account for the material brought to the surface (material per event times number of events) covering only a fraction of the disposal facility area. [For drilling events, the disposal facility area in this area reduction term is replaced by $100 \mathrm{~m}^{2}$ (ADRCREW), to account for the drilling crew staying in a relatively small area while drilling.]

Normal entrainment of surface waste into the atmosphere and resultant exposure to the public is modeled using Equation (21), but with an additional term DRILFRAC, which represents the fraction of the total waste in the disposal facility that is brought to the surface by the drilling. Exposure to the scavenger, drilling crew, and the residential family is modeled similarly, but with the term $\left(4 * 5 \mathrm{p}_{1-\mathrm{y}}\right)$ replaced with the term $\left(4 * 5\right.$ intruder $\left._{1-y}\right)$, as discussed previously in this section [Equation (24)].

\subsection{Environmental Cleanup Model}

The environmental cleanup model in ESHRAP estimates the human health and safety impacts resulting from the environmental cleanup of accidental releases of radionuclides or chemicals occurring 
during activities such as storage, treatment, or transportation. An accidental release of radionuclides or chemicals to the atmosphere results in a contaminated facility and an area of contaminated soil. D\&D of the facility must then be performed, resulting in both direct exposure to radionuclides and standard industrial injuries/fatalities. Cleanup of the soil also results in similar health impacts. ESHRAP also models accidental leakages into the soil. Cleanup from these leakages does not involve D\&D of facilities, but does include cleanup of the soil.

U.S. Nuclear Regulatory Commission studies covering nonreactor nuclear facilities were used to develop the environmental cleanup health risk model for ESHRAP. NRC (1990) reviewed historical releases of radionuclides at five reference facilities and the actual costs to D\&D the facilities and contaminated soil surrounding the facilities. Also, hypothetical accidents that had not occurred were postulated. Results for accidental release to the atmosphere indicated that the cleanup costs were a function of the toxicity-weighted amount of Ci's released in the accident and the population density surrounding the site. An approximate correlation for actual and predicted cleanup costs for accidental releases into the atmosphere is the following:

$$
\begin{aligned}
\text { Cleanup cost } \$=\quad & (1 \mathrm{a})\left(1 \mathrm{a}_{\text {decay }}\right)\left(1 \mathrm{~b}_{\text {inhalation }}\right)(2 \mathrm{a})\left(\sum 2 \mathrm{~b} * 3 \mathrm{a}+\sum 2 \mathrm{~b} * 3 \mathrm{~b}\right)(4 * 5 \mathrm{p} / 60)^{0.5} \\
& (\$ 1 \mathrm{E}+5 / \mathrm{Ci})(6) .
\end{aligned}
$$

Terms in Equation (27) are similar to those in Equation (4). This cleanup cost is calibrated to 1989 costs. DOE (1992) lists health physics personnel loaded labor rates (1989 rates) of approximately $\$ 56 / \mathrm{h}$. Also, laborer rates were approximately $\$ 34 / \mathrm{h}$. Using an average rate for a cleanup effort of $\$ 40 / \mathrm{h}$, the costs in Equation (27) can be divided by $\$ 40 / \mathrm{h}$ to determine the total hours required for the cleanup effort. Then assuming two involved workers to every one support personnel (the assumption for D\&D activities), the total hours are subdivided into involved worker total hours and support personnel total hours. Given the involved worker and support personnel total hours, the direct radiation exposure and standard industrial fatalities can be estimated using the models discussed in Sections 3.7 and 3.8.

Accident spill or leakage into the soil is also modeled. Information from NRC (1990) for liquid spills was reviewed and the following cost model was developed:

$$
\text { Cleanup cost }(4)=\quad(1 \mathrm{a})\left(1 \mathrm{a}_{\text {decay }}\right)\left(1 \mathrm{~b}_{\text {ingestion }}\right)\left(3 \mathrm{~b}_{\text {container leakage }}\right)(4 * 5 \mathrm{p} / 60)^{0.5}(\$ 1 \mathrm{E}+3 / \mathrm{Ci})(6) .
$$

This cleanup cost estimate for spills into the soil is then converted to involved worker and support total hours and then to direct radiation exposure and standard industrial fatalities.

\subsection{Risk Conversion to Dollars Model}

ESHRAP includes the capability to convert risk results (fatalities) to equivalent dollars. This model serves two purposes: it provides a means to weight radiological, chemical, and standard industrial fatalities differently and present the total ES\&H dollar impact, and it provides a mechanism to also incorporate the dollar impacts of injuries and cancers not resulting in fatalities. The costs of health risks occurring in the future are not discounted in the model.

Fatality costs assumed in ESHRAP are summarized in Table 36. Also shown in the table are costs associated with cancer incidence, and a variety of impacts from standard industrial injuries. Latent cancer fatalities were assigned a cost of $\$ 4,000,000 /$ fatality, based on the U.S. Nuclear Regulatory Commission practice of assigning a cost of $\$ 2,000 /$ rem when performing cost-benefit analyses (NRC 1995). Dividing $\$ 2,000 /$ rem by the conversion factor of $5 \mathrm{E}-4$ latent cancer fatality/rem results in $\$ 4,000,000 /$ fatality. The cost for a latent cancer incidence of $\$ 200,000$ is an estimate. Chemical cancer fatalities and incidences 
were assigned the same values as radiological events. The DOE CAIRS database was used to identify costs and frequencies associated with standard industrial injury-related events (DOE 2001b). Costs for impacts such as standard industrial fatalities, injuries resulting in termination or transfer, lost work days, etc. are those weights used in the DOE cost index discussed in the CAIRS database.

Frequencies for standard industrial injury-related events were determined from statistical analyses of DOE data covering the period 1995 - 2000, similar to the approach used to determine the standard industrial fatality rates for involved workers and support personnel (Section 3.8). Results are presented in Table 36 and are considered to be representative of DOE-wide performance for the year 2000.

For truck and rail transportation, death rates per accident are presented in Section 3.9. The injury rate per accident is 0.7 injuries/accident for both truck and rail transportation (Saricks and Thompkins 1999). Also, \$35,300/injury is used for transportation collisions (National Safety Council 2001).

Table 36. Dollar costs and frequencies for fatal and non-fatal health impact events.

\begin{tabular}{|c|c|c|c|c|}
\hline \multirow[t]{2}{*}{ Risk Category } & \multirow[t]{2}{*}{ Risk Event } & \multirow[t]{2}{*}{ Cost (\$) } & \multicolumn{2}{|c|}{ Frequency (worker hour ${ }^{-1}$ ) } \\
\hline & & & $\begin{array}{l}\text { Involved } \\
\text { Workers }\end{array}$ & $\begin{array}{c}\text { Support } \\
\text { Personnel }\end{array}$ \\
\hline \multirow{2}{*}{ Radiological } & Latent cancer incidence & 200,000 & $-\mathrm{-a}^{\mathrm{a}}$ & $-\mathrm{-a}^{\mathrm{a}}$ \\
\hline & Latent cancer fatality & $4,000,000$ & $-{ }^{a}$ & $-{ }^{a}$ \\
\hline \multirow{2}{*}{ Chemical } & Latent cancer incidence & 200,000 & $-{ }^{b}$ & $-{ }^{b}$ \\
\hline & Latent cancer fatality & $4,000,000$ & $-{ }^{b}$ & $--^{b}$ \\
\hline \multirow[t]{7}{*}{ Standard industrial } & Case not involving lost work & 2,000 & $7.6 \mathrm{E}-6$ & $2.3 \mathrm{E}-6$ \\
\hline & Case involving lost work & 2,000 & $5.9 \mathrm{E}-6$ & $1.5 \mathrm{E}-6$ \\
\hline & Work days lost & 1,000/day & 4.2E-5 day & 1.9E-5 day \\
\hline & Restricted work days & 400/day & $1.0 \mathrm{E}-4$ day & $5.9 \mathrm{E}-6$ day \\
\hline & Termination/transfer & 500,000 & $1.6 \mathrm{E}-8$ & 7.4E-9 \\
\hline & Fatality & $1,000,000$ & 8.6E-9 & $8.6 \mathrm{E}-10$ \\
\hline & Injury (transportation collision) & 35,300 & - & - \\
\hline
\end{tabular}

a. Radiological exposure (total person-rem) to workers, other site personnel, and the public results from accidental releases (from a range of accidents with varying frequencies) and from normal exposure. Therefore, there is no single, representative frequency associated with this exposure. Total person-rem exposure conversion to latent cancer incidence uses the conversion factor 1.7E-3 cancer incidence/rem for the public and 1.4E-3 for site personnel and workers. Conversion from total person-rem exposure to latent cancer fatalities uses 5.0E-4 cancer fatality/rem for the public and 4.0E-4 for site personnel and workers (ICRP 1990).

b. Chemical exposure (total latent cancer incidence) to workers, other site personnel, and the public results from accidental releases (from a range of accidents with varying frequencies) and from normal exposure. Therefore, there is no single, representative frequency associated with this exposure. The slope factor method results in estimates of the number of latent cancer incidences resulting from chemical exposures. Similar to radiological exposure, it is assumed that one in every 3.5 cancer incidences results in a fatality.

When ESHRAP fatality predictions (radiological, chemical, and standard industrial) are converted to dollars, the dollar impacts of cancer incidences and standard industrial injuries are also included. Including these non-fatal health impacts alters the fractional contribution to risk from these three contributors. For example, if an ESHRAP analysis predicted one radiological fatality, one chemical fatality, and one standard industrial fatality, then the total risk in fatalities is three, with each type of event contributing 33\%. However, if these results are then converted to risk in dollars, the radiological contribution is $\$ 4,000,000$ for the fatality and (3.5 cancer incidence/fatality)( $\$ 200,000 /$ cancer incidence) $=\$ 700,000$ for cancer incidences. The total radiological contribution is then $\$ 4,700,000$. The chemical result is identical, or $\$ 4,700,000$. Finally, standard industrial risk for one fatality is $\$ 1,000,000$. However, the number of worker-hours required to predict one standard industrial fatality also results in over 1500 injury-related events. The total cost for these injury-related events is $\$ 13,600,000$, resulting in a total of 
$\$ 14,600,000$ for standard industrial injuries and fatality. Therefore, when the radiological, chemical, and standard industrial fatalities are converted to dollars and non-fatal health impacts are also included, the percentage contribution to the total dollars $(\$ 24,000,000)$ changes from $33 \%$ for each to $20 \%, 20 \%$, and $60 \%$, respectively. 


\section{LEGACY RISK MODEL}

\subsection{Legacy Risk Concept}

Human health and safety risks from waste management and environmental restoration activities were covered in Section 3. To complete the ESHRAP model specifications outlined in Section 2, the ability to estimate the long-term risk of waste/material is needed. The legacy risk model in ESHRAP fulfills this need. Legacy risk is defined as a long-term (up to 10,000 years or longer) risk measure associated with waste/material in any form and location. As defined, the legacy risk measure is a generalization and enhancement of performance assessment risk, which is typically evaluated for 1,000 or 10,000 years following closure at disposal facilities. However, legacy risk covers the risk of waste/material at any point during its life cycle, not just during the disposal phase. Unlike a performance assessment, the risk is evaluated for both intruders (from multiple intrusion events) and the public within $80 \mathrm{~km}(50 \mathrm{mi})$. (Performance assessments typically evaluate whether the contaminant concentration in groundwater below the disposal facility at a specified distance from the facility meets regulatory requirements. Also, does a single occurrence of an intrusion event result in exposure greater than regulatory requirements?) Also, legacy risk is calculated using the same types of risk models used to predict risks from waste management and environmental activities. Therefore, risk benefit versus risk cost comparisons can be made to determine whether the risk reduction from an activity or program is greater than the risk incurred while performing the activity or program. Also, wastes and materials at a site can be ranked according to their legacy risks. Finally, total site legacy risk can be evaluated as a function of time to determine what activities contribute most to site risk reduction.

The legacy risk of a waste/material is evaluated over a long period of time assuming minimal action with respect to monitoring and controlling risks from the waste/material. Typically, such an analysis is performed by assuming institutional control (but no efforts to maintain waste containers or facilities) for 100 years, followed by a long period without institutional control and institutional knowledge (the "no action" alternatives in DOE $1997 \mathrm{~b}$ and DOE 2002c). The assumption of no action (beyond the institutional control period) provides a baseline measure of legacy risk, against which any other alternative (involving some sort of action) can be compared.

\subsection{Legacy Risk Activities}

Legacy risk evaluations in ESHRAP are performed using three types of activities. All three types are listed in Table 37. The institutional control activity covers the initial period of institutional control. Following this is the no institutional control activity covering the period from loss of institutional control until the waste/material containers and associated storage structure (if applicable) degrade. Finally, the degraded state activity is used for periods following complete degradation of containers and structures.

For the institutional control activity, construction of a fence around the waste/material in question is included. Also, a minimal number of involved workers are assumed to perform the institutional control. Otherwise, all of the legacy risk activities have no construction, operation, or D\&D personnel, because of the assumption of no or minimal action to protect intruders and the public from risks associated with the waste/material in question. However, risks to intruders and the public are evaluated.

Events modeled for each of the legacy risk activities are listed in Table 38. The institutional control events are those listed for storage activities in Section 3.5. In addition, scavenger intrusion events can be included (Section 3.10). However, the environmental cleanup risks associated with accidental releases to the atmosphere or the soil (discussed in Section 3.11) are not applicable, given the no action assumption. All of these events are modeled as discussed in Sections 3.5 and 3.10. 
Table 37. Legacy risk activity involved workers.

\begin{tabular}{|c|c|c|c|c|c|}
\hline \multirow{2}{*}{$\begin{array}{l}\text { Activity } \\
\text { Category }\end{array}$} & \multirow{2}{*}{ Activity Type } & \multirow{2}{*}{ Activity } & \multicolumn{3}{|c|}{ Number of Involved Workers for Large Facility/Activity } \\
\hline & & & Construction & Operations & $\begin{array}{l}\text { Decontamination } \\
\text { and } \\
\text { Decommissioning }\end{array}$ \\
\hline \multirow[t]{6}{*}{ Legacy Risk } & $\begin{array}{l}\text { Storage } \\
\text { (Aboveground) }\end{array}$ & $\begin{array}{l}\text { Institutional } \\
\text { control }\end{array}$ & $5^{\mathrm{a}}$ & 2.0 & - \\
\hline & & $\begin{array}{l}\text { No institutional } \\
\text { control }\end{array}$ & - & - & - \\
\hline & & Degraded state & - & - & - \\
\hline & $\begin{array}{l}\text { Storage } \\
\text { (Belowground) }\end{array}$ & $\begin{array}{l}\text { Institutional } \\
\text { control }\end{array}$ & $5^{\mathrm{a}}$ & 2.0 & - \\
\hline & & $\begin{array}{l}\text { No institutional } \\
\text { control }\end{array}$ & - & - & - \\
\hline & & Degraded state & - & - & - \\
\hline
\end{tabular}

a. Construction covers the building of a fence around the waste/material in question. A construction duration of 0.1 year is assumed.

For both no institutional control and degraded state activities, range fires, seismic events, strong wind events, and intrusion events are considered. However, if the waste is underground, then the range fires and strong wind events do not impact the waste and are not included. Waste that is initially underground may eventually be uncovered from soil entrainment. Once the waste is uncovered, then the range fires and strong wind events are included. Modeling of each of these events is discussed in Section 3.10 .

Finally, the degraded state activity also includes normal entrainment of waste, once the waste is exposed to the surface. Normal entrainment is discussed in Section 3.10.

Additional risks for scavengers (beyond those already discussed in Section 3.10) are included. If a facility is being considered (with or without waste/material stored inside), then before it completely collapses to the ground, it represents additional risks to scavengers. One additional risk is injury or death from climbing on the structure. The other risk is direct radiation exposure from areas within the structure with contamination or irradiated structures. These types of risk were not considered for disposal facilities because it was assumed that there would be no degrading, aboveground buildings during the post-closure period. To model the standard industrial risk to intruders (before the facility has collapsed to the ground), the total number of intruder hours is calculated as explained in Section 3.10. Then those hours are multiplied by a death rate and by the number of stories for the facility. (It is assumed that taller structures, with more stories, are more dangerous than single-story structures.) The death rate is assumed to be 1000 times higher (user input) than the DOE death rate for involved workers. This risk applies only to the institutional control and no institutional control activity types.

Direct radiation exposure from the facility is modeled similarly to direct radiation exposure from the waste/material [Equation (26) in Section 3.10]. However, the term IRF (initial radiation field) that typically comes from Table 35 is replaced by an effective radiation field within the facility:

$$
\mathrm{IRF}_{\text {facility }}=\left[\left(\mathrm{A}_{\mathrm{CA}}\right)\left(\mathrm{RF}_{\mathrm{CA}}\right)+\left(\mathrm{A}_{\mathrm{HCA}}\right)\left(\mathrm{RF}_{\mathrm{HCA}}\right)+\left(\mathrm{A}_{\mathrm{RA}}\right)\left(\mathrm{RF}_{\mathrm{RA}}\right)\right] /\left[\left(\mathrm{A}_{\text {Facility Footprint }}\right)(\mathrm{NS})\right]
$$

where $\mathrm{IRF}_{\text {facility }}$

$\mathrm{A}_{\mathrm{CA}}$

$\mathrm{A}_{\mathrm{HCA}}$

$\mathrm{A}_{\mathrm{RA}}$

$\mathrm{RF}_{\mathrm{CA}}$ $=\quad$ average initial radiation field within the facility $(\mathrm{rem} / \mathrm{h})$

$=\quad$ total floor area of contaminated areas within the facility $\left(\mathrm{m}^{2}\right)$

$=\quad$ total floor area of highly contaminated areas within the facility $\left(\mathrm{m}^{2}\right)$

$=\quad$ total floor area of radiation areas within the facility $\left(\mathrm{m}^{2}\right)$

$=\quad$ initial radiation field for contaminated areas $(0.010 \mathrm{rem} / \mathrm{h})$ 


$\begin{array}{lll}\mathrm{RF}_{\mathrm{HCA}} & = & \text { initial radiation field for highly contaminated areas }(1.0 \mathrm{rem} / \mathrm{h}) \\ \mathrm{RF}_{\mathrm{RA}} & = & \text { initial radiation field for radiation areas }(1.0 \mathrm{rem} / \mathrm{h}) \\ \mathrm{A}_{\text {Facility Footprint }} & = & \text { footprint area of facility }\left(\mathrm{m}^{2}\right) \\ \mathrm{NS} & = & \text { number of stories in facility. }\end{array}$

Also, the term $\left(1 \mathrm{a}_{\text {decay }}\right)$ is evaluated assuming the radiation fields decay like LLW. This direct radiation contribution applies to all three types of legacy risk activities.

Table 38. Legacy risk activity events.

\begin{tabular}{|c|c|c|c|c|}
\hline $\begin{array}{l}\text { Activity } \\
\text { Category }\end{array}$ & Activity Type & Activity & Event & Reference \\
\hline \multirow[t]{36}{*}{ Legacy Risk } & \begin{tabular}{|l} 
Storage \\
(Aboveground)
\end{tabular} & $\begin{array}{l}\text { Institutional } \\
\text { control }\end{array}$ & Natural phenomena & Table 9 \\
\hline & & & Facility fire & Table 10 \\
\hline & & & Facility explosion & Table 10 \\
\hline & & & Waste explosion & Table 10 \\
\hline & & & Container leakage & Table 10 \\
\hline & & & Intrusion (scavenger) & Table 33 \\
\hline & & $\begin{array}{l}\text { No institutional } \\
\text { control }\end{array}$ & Range fire & Table 31 \\
\hline & & & Seismic & Table 31 \\
\hline & & & Strong wind & Table 31 \\
\hline & & & Intrusion (scavenger) & Table 33 \\
\hline & & & Intrusion (residential) & Table 33 \\
\hline & & & Intrusion (drilling) & Table 33 \\
\hline & & Degraded state & Range fire & Table 31 \\
\hline & & & Seismic & Table 31 \\
\hline & & & Strong wind & Table 31 \\
\hline & & & Normal entrainment & Table 31 \\
\hline & & & Intrusion (scavenger) & Table 33 \\
\hline & & & Intrusion (residential) & Table 33 \\
\hline & & & Intrusion (drilling) & Table 33 \\
\hline & \begin{tabular}{|l|} 
Storage \\
(Belowground)
\end{tabular} & $\begin{array}{l}\text { Institutional } \\
\text { control }\end{array}$ & Natural phenomena & Table 9 \\
\hline & & & Waste explosion & Table 10 \\
\hline & & & Container leakage & Table 10 \\
\hline & & & Intrusion (scavenger) & Table 33 \\
\hline & & $\begin{array}{l}\text { No institutional } \\
\text { control }\end{array}$ & Range fire $^{a}$ & Table 31 \\
\hline & & & Seismic & Table 31 \\
\hline & & & Strong wind $^{\mathrm{a}}$ & Table 31 \\
\hline & & & Intrusion (scavenger) & Table 33 \\
\hline & & & Intrusion (residential) & Table 33 \\
\hline & & & Intrusion (drilling) & Table 33 \\
\hline & & Degraded state & Range fire $^{\mathrm{a}}$ & Table 31 \\
\hline & & & Seismic & Table 31 \\
\hline & & & Strong wind ${ }^{\mathrm{a}}$ & Table 31 \\
\hline & & & Normal entrainment $^{\mathrm{a}}$ & Table 31 \\
\hline & & & Intrusion (scavenger) & Table 33 \\
\hline & & & Intrusion (residential) & Table 33 \\
\hline & & & Intrusion (drilling) & Table 33 \\
\hline
\end{tabular}

a. These events apply only after waste is exposed to the surface (from gradual erosion of the soil cover). 


\section{EXAMPLE ANALYSES}

Seven sample ESHRAP analyses are presented in this section, each illustrating one of the types of applications specified in Section 2. (Note that even though the examples are based on INEEL waste management and environmental restoration programs, the results do not necessarily represent current site plans or philosophies. Also, some of the example analyses were performed with earlier versions of ESHRAP, so results may not be consistent between examples. However, within a given example, results are consistent.) Figure 5 illustrates the use of the ESHRAP code to estimate activity risks for an entire program. The program addresses aboveground, CH-TRUW at the INEEL. This waste is presently stored in buildings and berms. All of this waste will be retrieved, characterized, processed (as needed), and shipped to WIPP for final disposal. Shown in Figure 5 are initial efforts to ship $3100 \mathrm{~m}^{2}$ of waste to WIPP followed by the retrieval of the remaining CH-TRUW. Activities modeled include initial storage (buildings and berms), retrieval, characterization, sorting, compaction, treatment, transportation, loading and unloading, and disposal. The risk measure presented in Figure 5 is dollars, combining environmental impacts (safety and health impacts while cleaning up radiological and chemical releases caused by accidents during the program activities), standard industrial injuries/deaths, and radiological and chemical latent cancer incidences and fatalities. As indicated in Figure 5, risks are dominated by the transport of the CH-TRUW from the INEEL to WIPP. Also, much of this transportation risk is the result of injuries and deaths from truck accidents not involving releases of radionuclides.

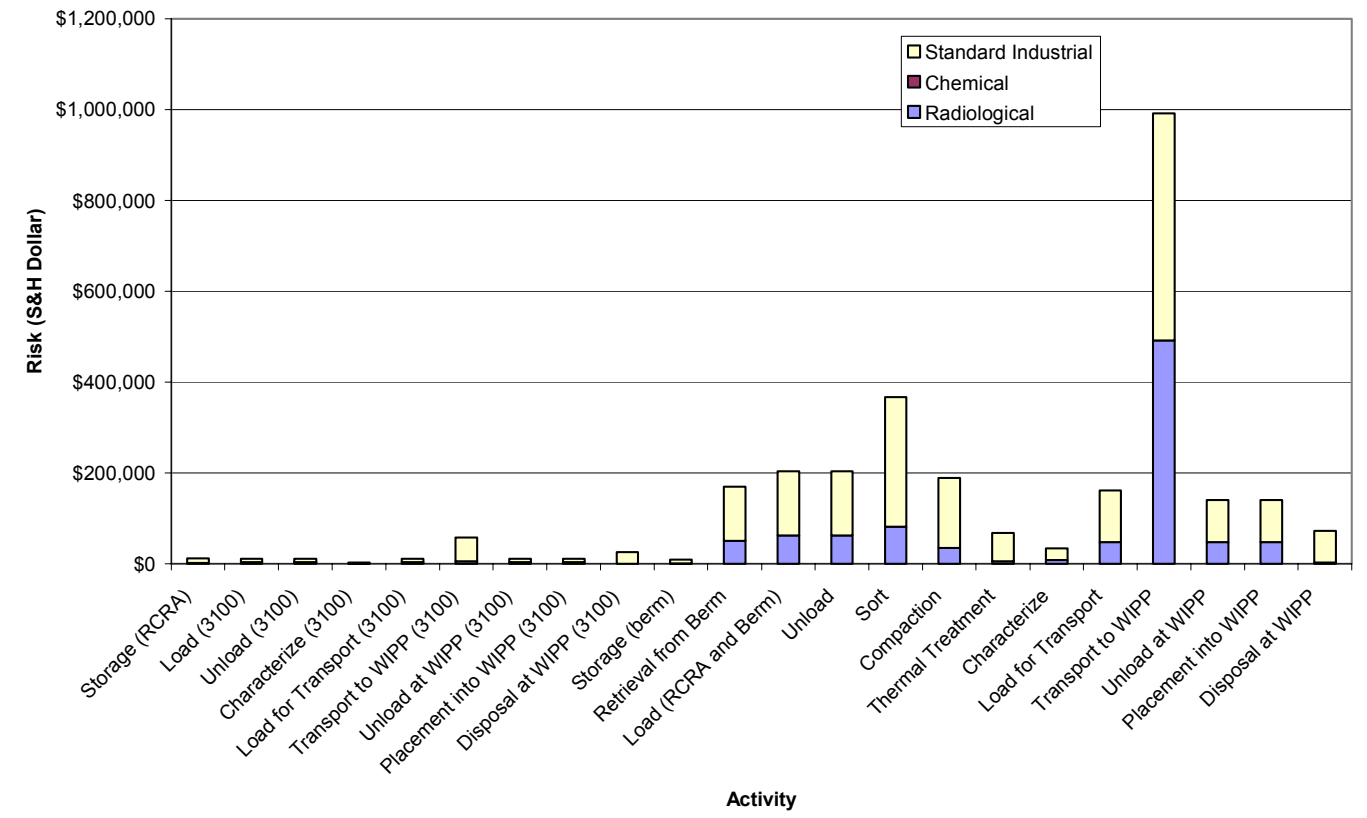

Figure 5. CH-TRUW (aboveground) activity risks.

A second application is presented in Figure 6. Shown in the figure are the total activity risks (fatalities) for three alternative programs for buried TRUW at the INEEL. The three programs are the following:

- Retrieval, treatment, and shipment to WIPP (baseline)

- In-situ grouting and capping 
- Capping only.

The most risk is incurred by retrieving the waste, treating, and shipping to WIPP for disposal.

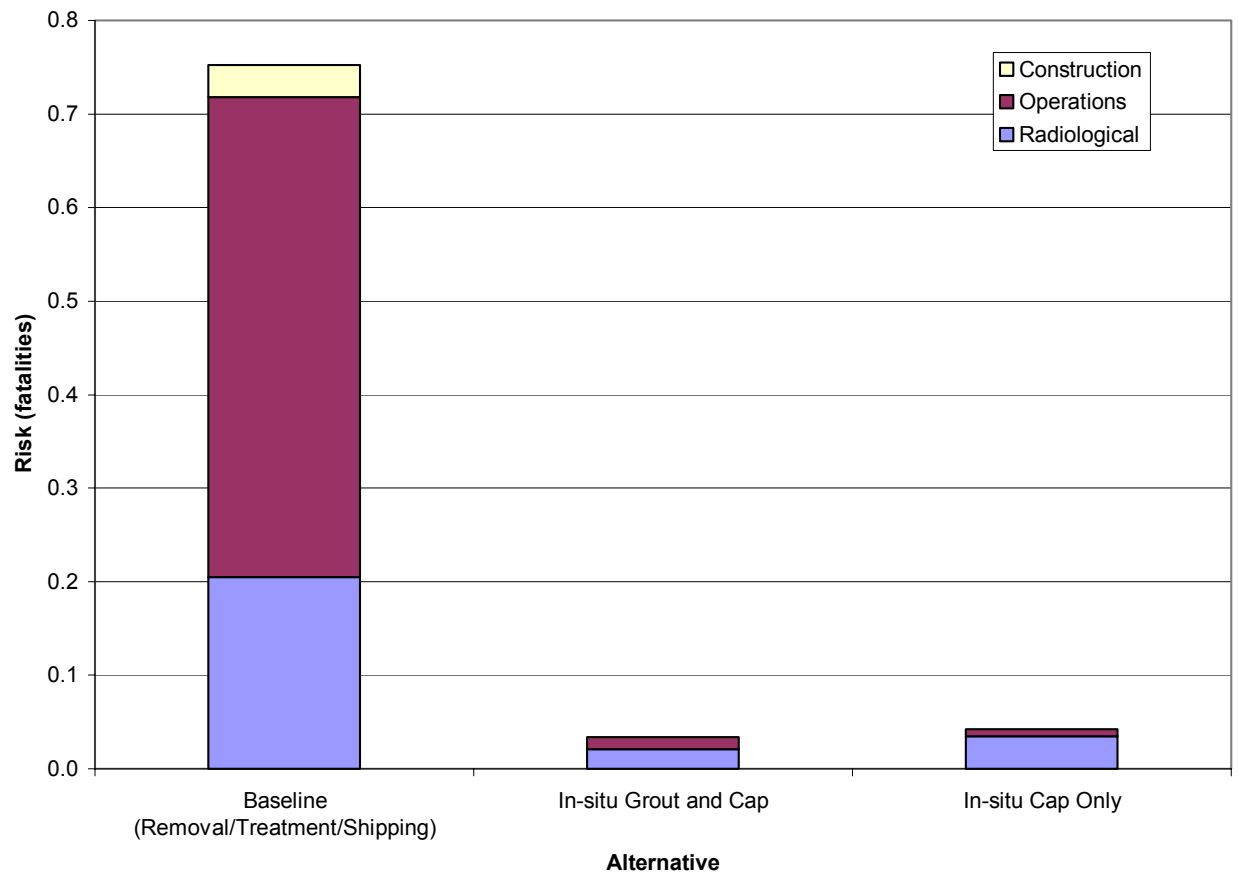

Figure 6. Buried TRUW program alternative risks.

Shown in Figure 7 are the S\&H risk benefits versus risk costs from each of the three program alternatives for buried TRUW. The risk benefit is defined as the legacy risk measure of the waste before the program occurs minus the legacy risk measure of the waste after the program occurs. In the case of retrieval, treatment, and shipping to WIPP, the waste ends up in disposal at WIPP. However, for the other two programs, the waste remains buried (and capped) at the INEEL. As shown in Figure 7, the risk benefit is greater than the risk cost for all three alternatives. However, the ratio of risk benefit to risk cost is much greater for the two alternatives that leave the waste in the ground. Also, if it is assumed that the waste (covered by only 0.6 meter of soil in some places) is not uncovered at anytime during the 10,000year period used to calculate the legacy risk, then the risk benefit drops dramatically. In that case, the baseline program actually has a greater risk cost than risk benefit.

Figure 8 presents a comparison or ranking of program risks for various types of wastes and materials at the INEEL. Shown are programs for aboveground TRUW and belowground TRUW, HLW, SNF, LLW, MLLW, and SNM. The program for buried TRUW was defined to include retrieval, treatment, and shipping to WIPP. As indicated in the figure, the TRUW programs have the most risk, while the MLLW and SNM programs have the least. 


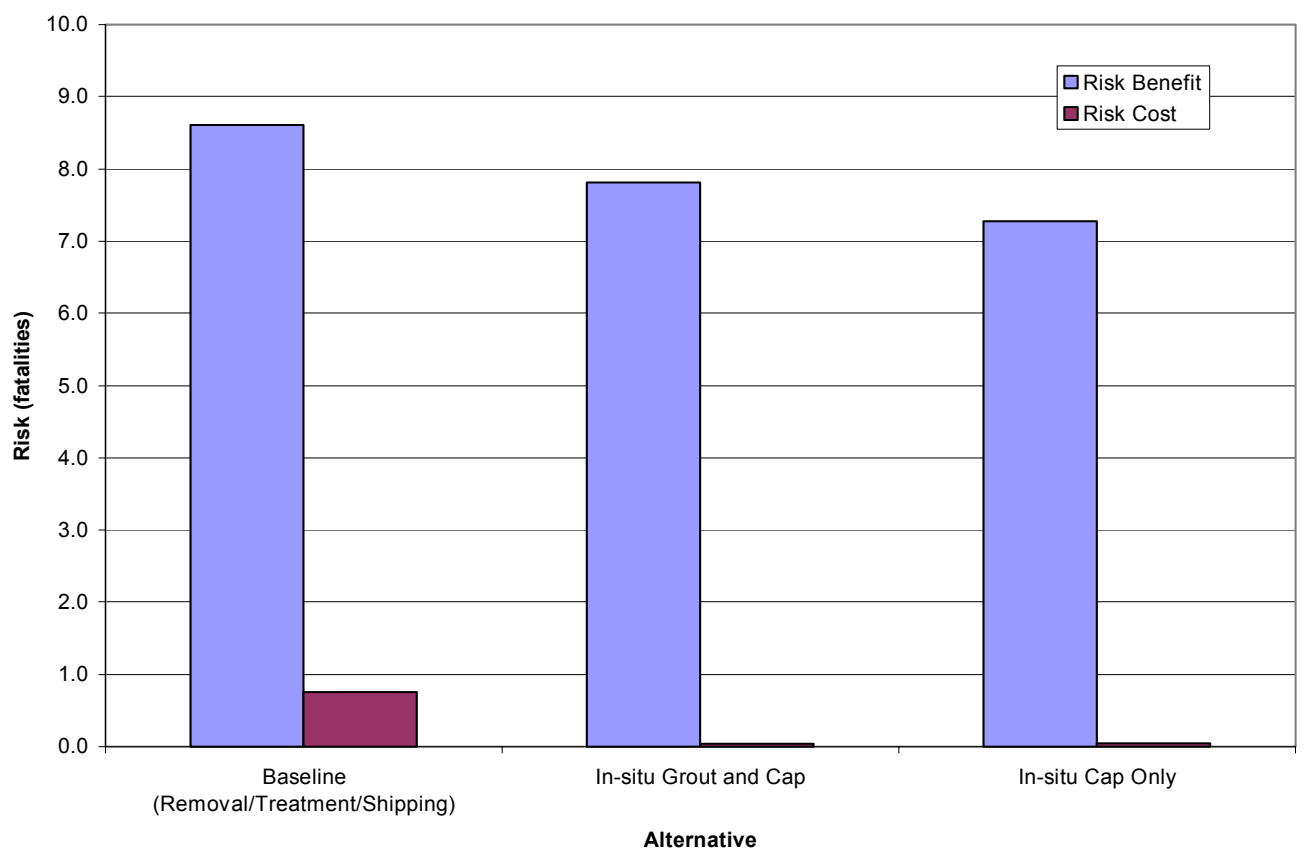

Figure 7. Risk benefit versus risk cost for buried TRUW program alternatives.

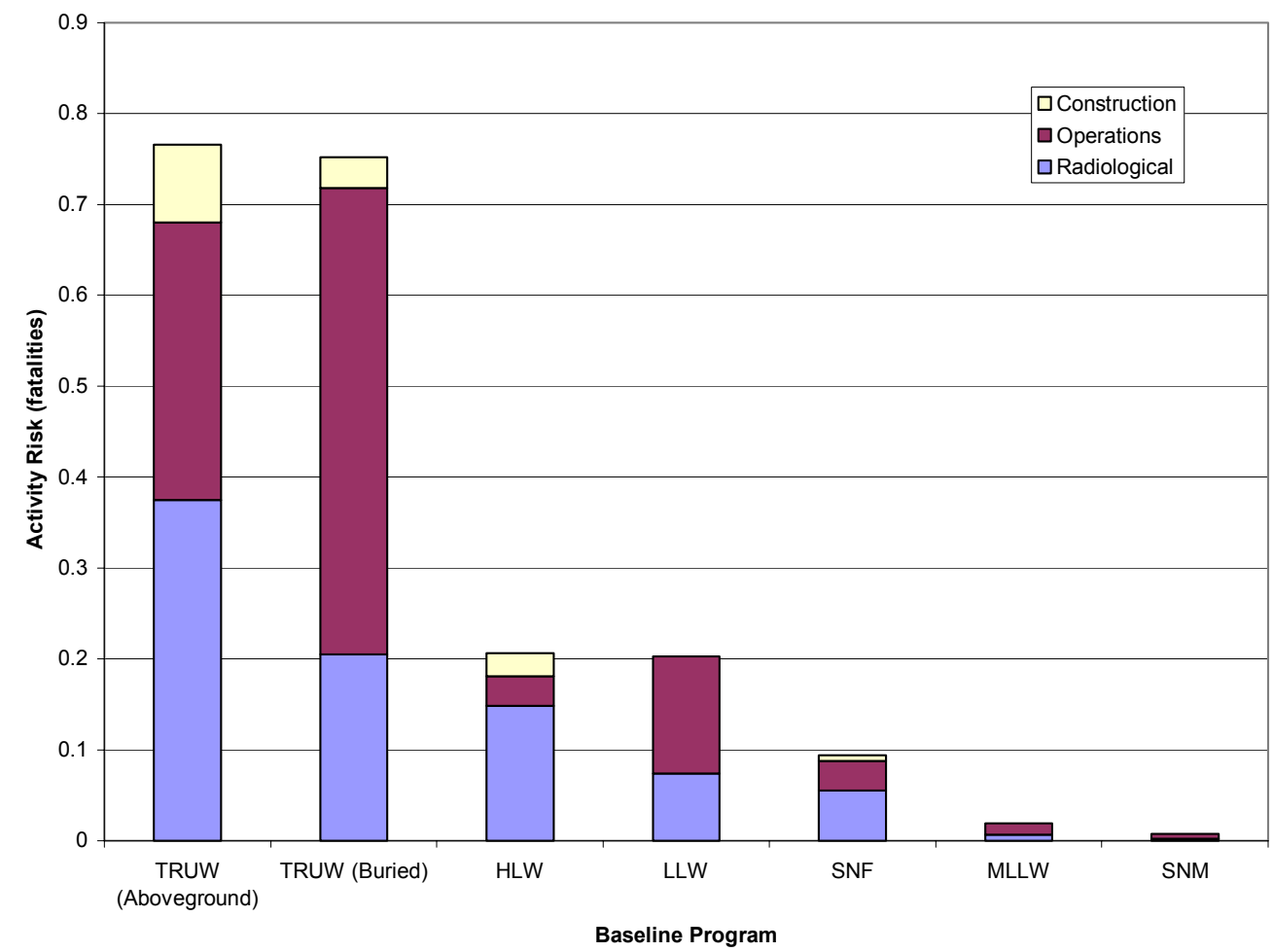

Figure 8. INEEL environmental management program activity risks. 
A preliminary risk ranking of wastes/materials at the INEEL is presented in Figure 9. The longterm legacy risk measure is used to evaluate waste/material risks assuming minimal action is performed in the future to prevent exposures. Aboveground TRUW dominates the risk, while MLLW has the least risk.

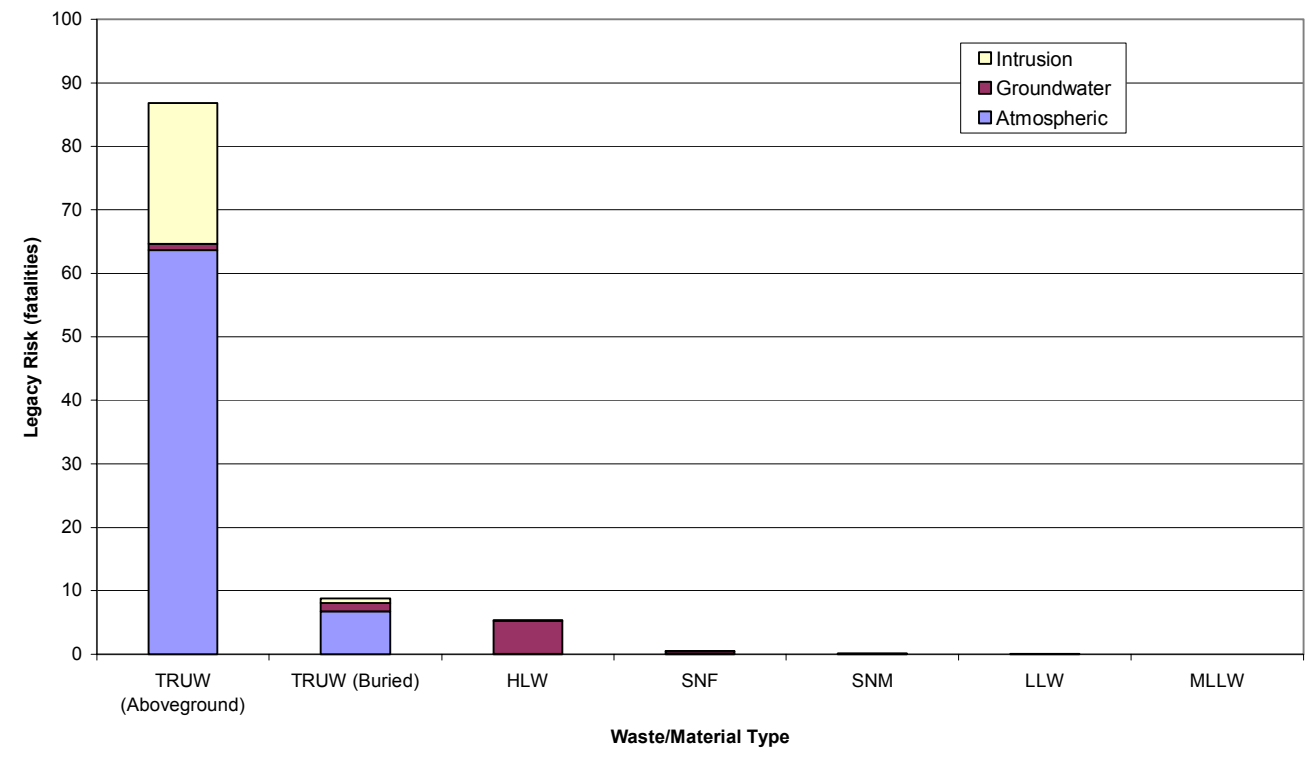

Figure 9. INEEL environmental management waste/material risks.

Figure 10 presents an INEEL site risk curve with time as environmental management programs progress. The program to ship aboveground TRUW to WIPP dominates this risk curve. As aboveground TRUW is shipped to WIPP (over the period 2000 to 2015), the site risk drops dramatically. Although not nearly as dramatic, the shipment of HLW to the Yucca Mountain repository also helps to reduce the site risk. Other program activities have significantly less impact on reducing the site risk with time and are not shown in the figure.

Finally, Figure 11 illustrates how the INEEL environmental management risk model could be used as in integrated indicator of performance. A preliminary analysis indicates that the baseline risk total for all INEEL environmental management programs (initial status through final disposition) is approximately two fatalities. As indicated in Figure 11, this total includes contributions from the following types of events:

- Construction accidents causing injury or death (0.15 fatality)

- Standard industrial accidents causing injury or death (0.21 fatality)

- Transportation accidents causing injury or death (0.84 fatality)

- Normal radiological exposure to workers (0.38 fatality)

- Normal radiological exposure to truck crew and public from transportation (0.36 fatality)

- Radiological exposure from accidental releases of radionuclides ( 0.10 fatality).

This risk estimate was obtained using performance data (injury and death rates for standard industrial accidents, personnel radiological exposure, truck accident rates, etc.) representative of the entire DOE complex. 


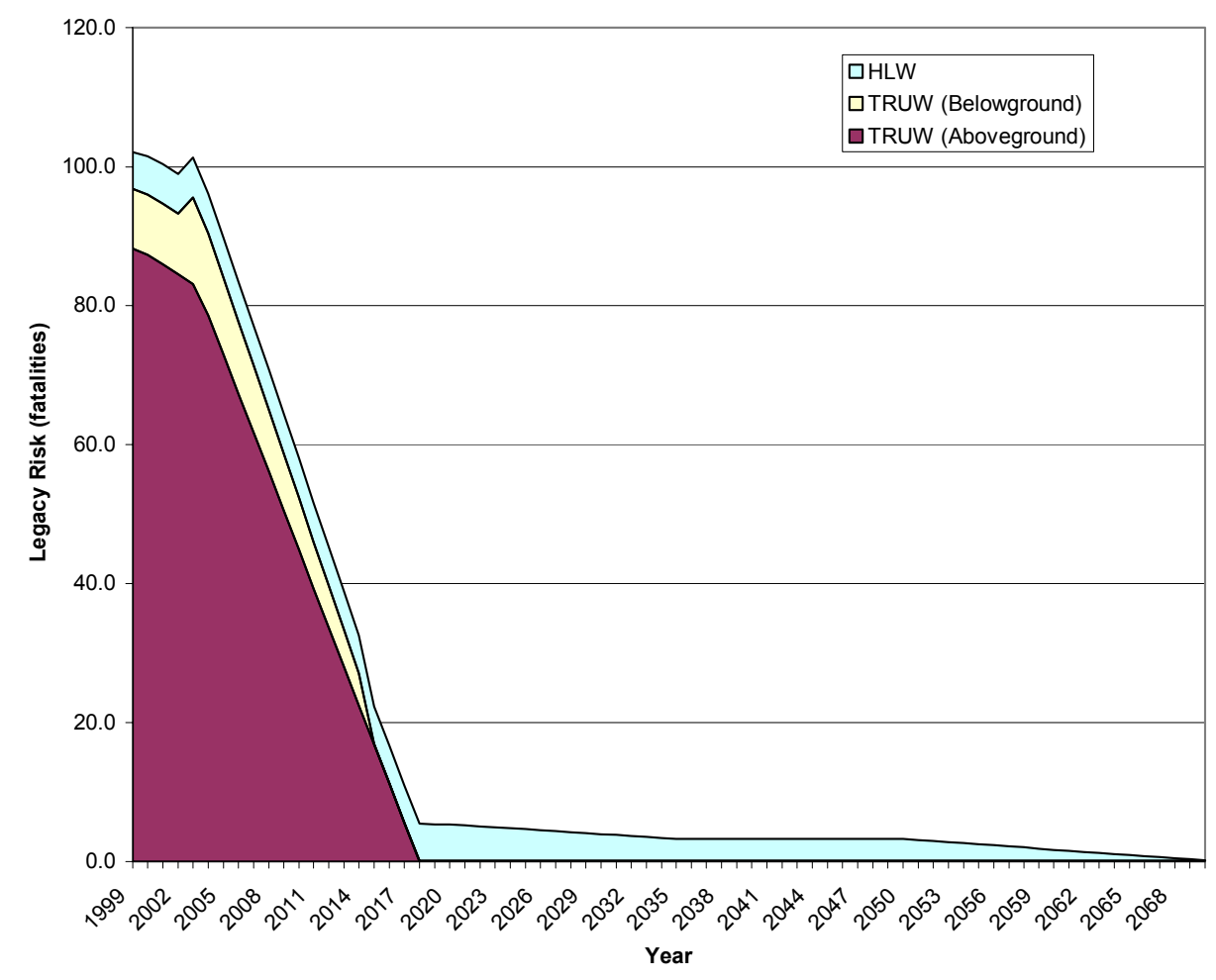

Figure 10. INEEL site risk curve.

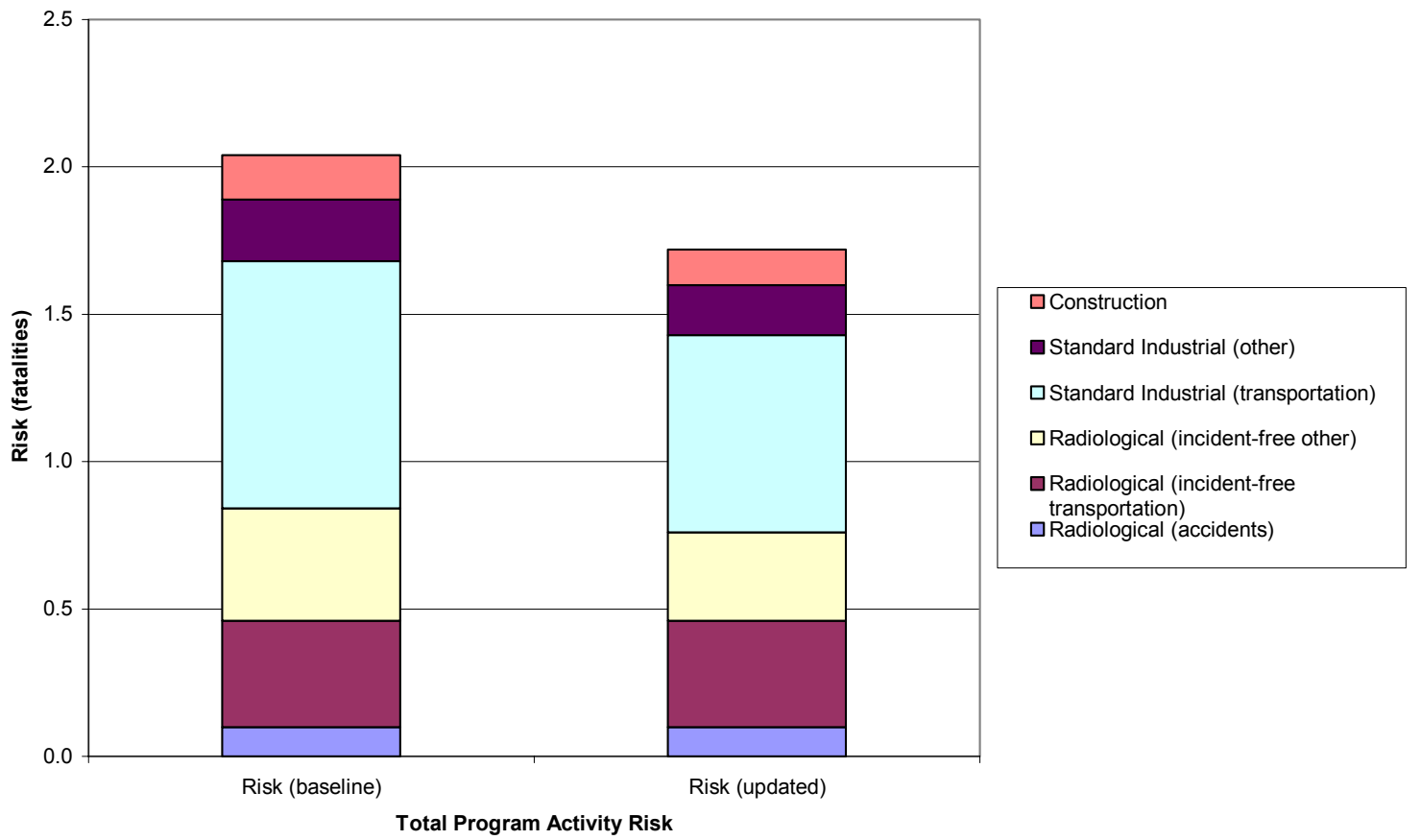

Figure 11. INEEL environmental management program risk integrated indicator. 
To use this total risk model as an integrated indicator of performance at the INEEL, assume that various safety programs result in a $20 \%$ reduction in construction and standard industrial accident rates at the INEEL, compared with averages for the entire complex. If this performance were maintained until environmental management programs are completed, then the construction and standard industrial accident fatalities ( 0.15 and 0.21 , respectively) would be reduced by $20 \%$. Also, assume that the ALARA program reduces personnel radiological exposures by $20 \%$. This would reduce the radiological (incident free other) fatalities by $20 \%$. Finally, assume that the offsite transportation program (not controlled by the INEEL) efforts reduce the truck accident rates by $20 \%$. This would reduce the standard industrial (transportation) fatalities by $20 \%$. These performance improvement assumptions are presented in Figure 11 by the updated risk estimate. As can be seen in the figure, the total risk is reduced by approximately 0.3 fatality. Note that this model could also evaluate program or schedule changes that might result in more or less activity risk than the baseline. 


\section{REFERENCES}

Becker, B. H. et al., 1998, Interim Risk Assessment and Contaminant Screening for the Waste Area Group 7 Remedial Investigation, DOE/ID-10569, Idaho National Engineering and Environmental Laboratory, August 1998.

Blaylock, B. P. et al., 1995, U.S. Department of Energy Public and Onsite Population Health Risk Evaluation Methodology for Assessing Risks Associated with Environmental Restoration and Waste Management, ORNL-6832, Oak Ridge National Laboratory, May 1995.

Dettmers, D.L., 2002, Constructing Predictive Estimates for Worker Exposure to Radioactivity During Decommissioning: Analysis of Completed Decommissioning Projects, Masters Thesis, University of Idaho, October 2002.

Durant, W. S., S. A. Eide, and R. S. Shay, 1993, Savannah River Site Integrated Seismic Risk Evaluation (U), WSRC-TR-92-563, Westinghouse Savannah River Company, April 1993.

DOE, 2003, Risk Assessment Information System (RAIS), U.S. Department of Energy, http://risk.lsd.ornl.gov/, accessed on April 9, 2003.

DOE, 2002a, Idaho High-Level Waste \& Facilities Disposition Final Environmental Impact Statement, DOE/EIS-0287, U.S. Department of Energy, September 2002.

DOE, 2002b, Transuranic Waste Performance Management Plan, U.S. Department of Energy, Carlsbad Field Office, August 2002.

DOE, 2002c, Final Environmental Impact Statement for a Geologic Repository for the Disposal of Spent Nuclear Fuel and High-Level Radioactive Waste at Yucca Mountain, Nye County, Nevada, DOE/EIS0250F, U.S. Department of Energy, February 2002.

DOE, 2001a, DOE Occupational Radiation Exposure, 2000 Report, DOE/EH-0629, U.S. Department of Energy, 2001.

DOE, 2001b, Computerized Accident/Injury Reporting System (CAIRS), U.S. Department of Energy, http://tis-nt.eh.doe.gov/cairs/, accessed on February 26, 2001.

DOE, 1997a, Final Waste Management Programmatic Environmental Impact Statement for Managing Treatment, Storage, and Disposal of Radioactive and Hazardous Waste, DOE/EIS-0200-F, U.S. Department of Energy, April 1997.

DOE, 1997b, Waste Isolation Pilot Plant Disposal Phase Final Supplemental Environmental Impact Statement, DOE/EIS-0026-S-2, U.S. Department of Energy, September 1997.

DOE, 1996a, Integrated Data Base Report-1995: U.S. Spent Nuclear Fuel and Radioactive Waste Inventories, Projections, and Characteristics, DOE/RW-0006, Rev. 12, December 1996.

DOE, 1996b, Performance Evaluation of the Technical Capabilities of DOE Sites for Disposal of Mixed Low-Level Waste, DOE/ID-10521, U.S. Department of Energy, March 1996. 
DOE, 1995, Department of Energy Programmatic Spent Nuclear Fuel Management and Idaho National Engineering Laboratory Environmental Restoration and Waste Management Programs Final Environmental Impact Statement, DOE/EIS-0203-F, U.S. Department of Energy, April 1995.

DOE, 1994, Airborne Release Fractions/Rates and Respirable Fractions for Nonreactor Nuclear Facilities, DOE-HDBK-3010-94, U.S. Department of Energy, December 1994.

DOE, 1992a, Natural Phenomenal Hazards Performance Categorization Criteria for Structures, Systems, and Components, DOE-STD-1021-92, U.S. Department of Energy, December 1992.

DOE, 1992b, Hazard Categorization and Accident Analysis Techniques for Compliance with DOE Order 5480.23, Nuclear Safety Analysis Reports, DOE-STD-1027-92, U.S. Department of Energy, December 1992.

DOE, 1988, Internal Dose Conversion Factors for Calculation of Dose to the Public, DOE/EH-0071, U.S. Department of Energy, July 1988.

Eide, S. A. et al., 1996, A Simplified Method for Quantitative Assessment of the Relative Health and Safety Risk of Environmental Management Activities, INEL-95/0645, Idaho National Engineering Laboratory, September 1996.

Envirocare, 2003, http://www.envirocareutah.com/, accessed on February 23, 2003.

EPA, 2002, Integrated Risk Information System (IRIS), U.S. Environmental Protection Agency, Office of Research and Development, National Center for Environmental Assessment, updated through September 19, 2002, URL:http://www.epa.gov/iris/index.html.

EPA, 1989, Risk Assessment Guidance for Superfund Volume 1 Human Health Evaluation Manual (Part A), EPA/540/1-89/002, U.S. Environmental Protection Agency, December 1989.

Feizollahi, Fred and David Shropshire, 1993, Waste Management Facilities Cost Information Report for Spent Nuclear Fuel, EGG-WM-10670, Idaho National Engineering Laboratory, March 1993.

ICRP, 1990, Recommendations of the International Commission on Radiological Protection, ICRP Publication 60, International Commission on Radiological Protection, Pergammon Press, New York, 1990.

INEEL, 2000, SDA alternatives analysis document.

INEEL, 2002, Safety Analysis Report for Sixth Calcined Solids Storage Facility, SAE-106, Rev. 0, Idaho National Engineering and Environmental Laboratory, January 2002.

Moss, M. et al., 1995, Programmatic Environmental Impact Statement Installation Descriptions, ORNL6841, Revision 1, Oak Ridge National Laboratory, April 1995.

Napier, B. A. et al., 1988, GENII - The Hanford Environmental Radiation Dosimetry Software System, PNL-6548, Pacific Northwest Laboratory, 1988.

National Safety Council, 2001, Injury Facts, 2001 Edition, National Safety Council, 2001. 
NRC, 1995, Assessment of NRC's Dollar Per Person-Rem Conversion Factor Policy, NUREG-1530, U.S. Nuclear Regulatory Commission, 1995.

NRC, 1992, Generic Cost Estimates, NUREG/CR-4627, Revision 2, U.S. Nuclear Regulatory Commission, February 1992.

NRC, 1990, Economic Risk of Contamination Cleanup Costs Resulting from Large Nonreactor Nuclear Material Licensee Operations, NUREG/CR-5381, U.S. Nuclear Regulatory Commission, March 1990.

NRC, 1983, PRA Procedures Guide, NUREG/CR-2300, U.S. Nuclear Regulatory Commission, January 1983.

OSHA, 1997, 29 CFR 1910, "Occupational Safety and Health Standards," Subpart Z, "Toxic and Hazardous Substances," Code of Federal Regulations, Office of the Federal Register, August 1997.

Public Law 91-190, 1970, “National Environmental Policy Act,” U.S. Congress, January 1, 1970.

Rood, A. S., 1993, A Semi-Analytical Model for Assessment of the Groundwater Pathway from Surface of Buried Contamination: Version 2.0 Theory and User's Manual, EGG-GEO-10797, Idaho National Engineering Laboratory, 1993.

SNL, 1992, Preliminary Performance Assessment for the Waste Isolation Pilot Plant, SAND92-070013, Sandia National Laboratories, December 1992.

Saricks, C. L. and M. M. Thompkins, 1999, State-Level Accident Rates of Surface Freight Transportation: A Reexamination, ANL/ESD/TM-150, Argonne National Laboratory, Center for Transportation Research, April 1999.

Shropshire, David, Michael Sherick, and Chuck Biagi, 1995a, Waste Management Facilities Cost Information for Transuranic Waste, INEL-95/0015, Rev. 1, Idaho National Engineering Laboratory, June 1995.

Shropshire, David, Michael Sherick, and Chuck Biagi, 1995b, Waste Management Facilities Cost Information for Low-Level Waste, INEL-95/0013, Rev. 0, Idaho National Engineering Laboratory, June 1995.

Smith, T. H. et al., 1995, Preliminary Parametric Performance Assessment of Potential Final Waste Forms for Alpha Low-Level Waste at the Idaho National Engineering Laboratory, INEL-95/0095, Idaho National Engineering Laboratory, August 1995.

WINCO, 1987, Final Safety Analysis Report for the ICPP Sixth Calcined Solids Storage Facility, WIN101, Westinghouse Idaho Nuclear Company, July 1987. 